\title{
Profits and Balance Sheet Developments at U.S. Commercial Banks in 2003
}

Mark Carlson and Roberto Perli, of the Board's Division of Monetary Affairs, prepared this article. Thomas C. Allard assisted in developing the database underlying much of the analysis. Jason Grimm and Steve Piraino provided research assistance.

The U.S. commercial banking industry remained highly profitable in 2003. The return on assets at banks surpassed the previous year's record level, and the return on equity approached the top of its recent range (chart 1). Banks' profits and balance sheets were shaped in part by the financial and economic conditions that prevailed during the year. Perhaps most important, monetary policy remained highly accommodative. The Federal Reserve reduced the intended federal funds rate at midyear from an already low level; and with short-term rates anchored by policy, longer-term interest rates, although volatile, generally remained low (chart 2). Home mortgage interest rates dropped to very low levels in the first half of the year, and yields on many corporate bonds, especially non-investment-grade bonds, fell

Note. Except where otherwise indicated, data in this article are from the quarterly Reports of Condition and Income (Call Reports) for insured domestic commercial banks and nondeposit trust companies (hereafter, banks). The data consolidate information from foreign and domestic offices and have been adjusted to take account of mergers. For additional information on the adjustments to the data, see the appendix in William B. English and William R. Nelson, "Profits and Balance Sheet Developments at U.S. Commercial Banks in 1997,", Federal Reserve Bulletin, vol. 84 (June 1998), p. 408. Size categories, based on assets at the start of each quarter, are as follows: the ten largest banks, large banks (those ranked 11 through 100), mediumsized banks (those ranked 101 through 1,000), and small banks. At the start of the fourth quarter of 2003, the approximate asset sizes of the banks in those groups were as follows: the ten largest banks, more than $\$ 92$ billion; large banks, $\$ 7.2$ billion to $\$ 92$ billion; mediumsized banks, $\$ 398$ million to $\$ 7.1$ billion; and small banks, less than $\$ 398$ million.

Many of the data series reported here begin in 1985 because the Call Reports were significantly revised in 1984. Data for 1984 and earlier years are taken from the Federal Deposit Insurance Corporation, Historical Statistics on Banking, 1999. The pre-1985 data reported here are also available on the Internet at www2.fdic.gov/ hsob/index.asp.

Data shown in this article may not match data published in earlier years because of revisions and corrections. In the tables, components may not sum to totals because of rounding. Appendix table A.1 reports income statement data for all banks. Appendix table A.2, A-E, reports portfolio composition, income, and expense items, all as a percentage of overall net consolidated assets. noticeably as risk spreads contracted to the lowest levels in more than five years.

This supportive interest rate backdrop, coupled with stimulative fiscal policy, helped broaden and strengthen the economic expansion last year. Household spending continued to be strong. Low residential mortgage rates spurred home sales to record levels, and mortgage refinancing swelled. Low interest rates, along with the attractive incentives for automobile purchases, contributed to a pickup in spending on consumer durables. Also, many corporations took advantage of attractive costs of funds to strengthen their balance sheets, often by issuing longterm debt and using the proceeds to pay down commercial paper and bank loans. The pickup in aggregate spending, together with continued favorable productivity trends, boosted corporate profits. And in the second half of the year, brighter business prospects finally began to show through to equipment spending, which had been anemic for several quarters.

These economic developments left an imprint on banks' balance sheets. The strength of the housing market and the record levels of refinancing activity boosted the share of total bank assets accounted for by residential mortgages and mortgage-backed securities to 28.5 percent by the end of 2003. Business loans declined for the third consecutive year as businesses used the proceeds of bond issuance to pay

\section{Measures of bank profitability, 1985-2003}

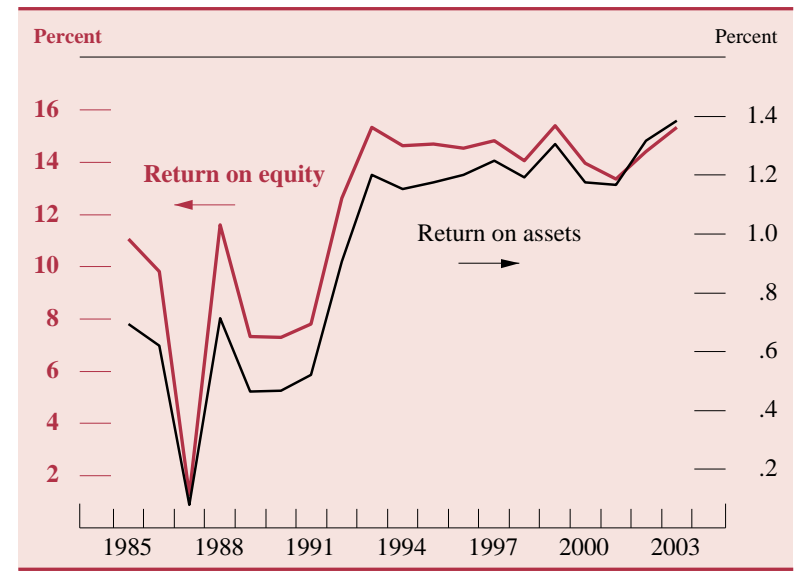




\section{Selected interest rates, 1999-2004:Q1}

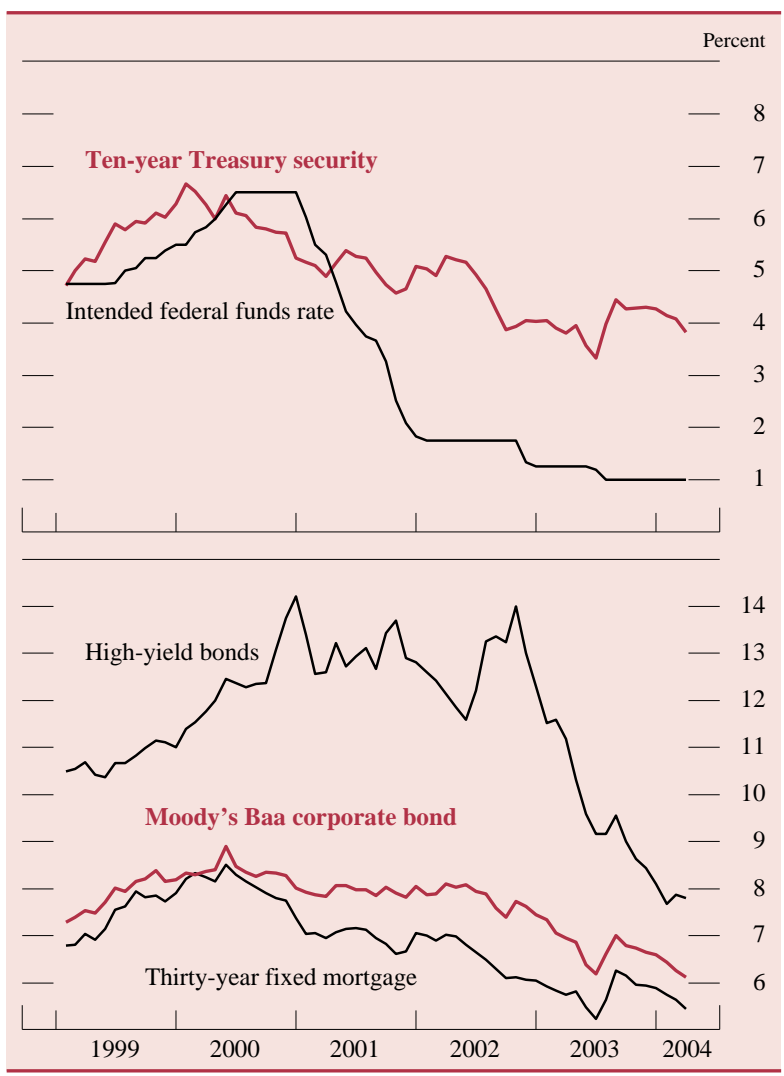

SOURCE. Data are monthly. For the intended federal funds rate, Federal Reserve Board (www.federalreserve.gov/fomc/fundsrate.htm); for Treasury security rates, mortgage rate, and Moody's bond rates, Federal Reserve Board, Statistical Release H.15, "Selected Interest Rates" (www.federalreserve.gov/releases/h15); for high-yield bond rates, Merrill Lynch Master II index.

down short-term debt and financed many of their investment outlays with internal funds. But the runoff was slower in 2003 than in 2001 and 2002, and as equipment spending recovered and inventories were built up late in the year, demand for business loans showed signs of turning around. Inflows of core deposits remained strong, as deposit rates fell less than market yields and households responded to the low opportunity cost of holding liquid assets.

Economic developments also significantly affected banks' profitability. The wave of residential mortgage refinancing led to a surge in income from fees associated with the origination, sale, and servicing of these loans. An elevated level of corporate bond issuance supported investment banking income. Debt refinancing led to a reduction in borrowers' debt-service burdens, which in turn lowered delinquency rates. The decline in interest rates, especially during the first half of the year, allowed banks to realize gains by selling some of their investment securities; however, it also likely contributed to a further narrowing of net interest margins.
With increasing business profitability and lower business debt-service burdens, delinquency rates on commercial and industrial loans, which had risen in the previous three years, dropped back notably. Because of lower residential mortgage interest rates and increased house prices, households could extract equity from their homes by taking out cash through either refinancing or home equity loans; the proceeds were used partly to pay down higher-rate debt. With the credit quality of their loan portfolios improving considerably during the year, banks were able to reduce loan-loss provisions; such reduction was a substantial contributor to the increase in bank profitability.

The number of commercial banks in the United States moved down to 7,825 at the end of 2003 from 7,936 a year earlier-the smallest decrease in more than a decade (chart 3). ${ }^{1}$ The decline occurred as the number of mergers-which fell to 245, also the smallest number in more than a decade-continued to exceed the number of new bank charters, which was slightly higher last year. According to the Federal Deposit Insurance Corporation, only three banks failed in 2003. These banks held $\$ 1.1$ billion in assets at the time of failure, a tiny fraction of industry assets and less than half the assets at failed banks during 2002. The shares of industry assets held by

1. This count of commercial banks may vary slightly from measures, such as those in the Federal Reserve's Annual Report, that are based on the definition of a bank given in the Bank Holding Company Act and implemented in the Federal Reserve's Regulation Y.

3. Number of banks and share of assets at the largest banks, 1985-2003

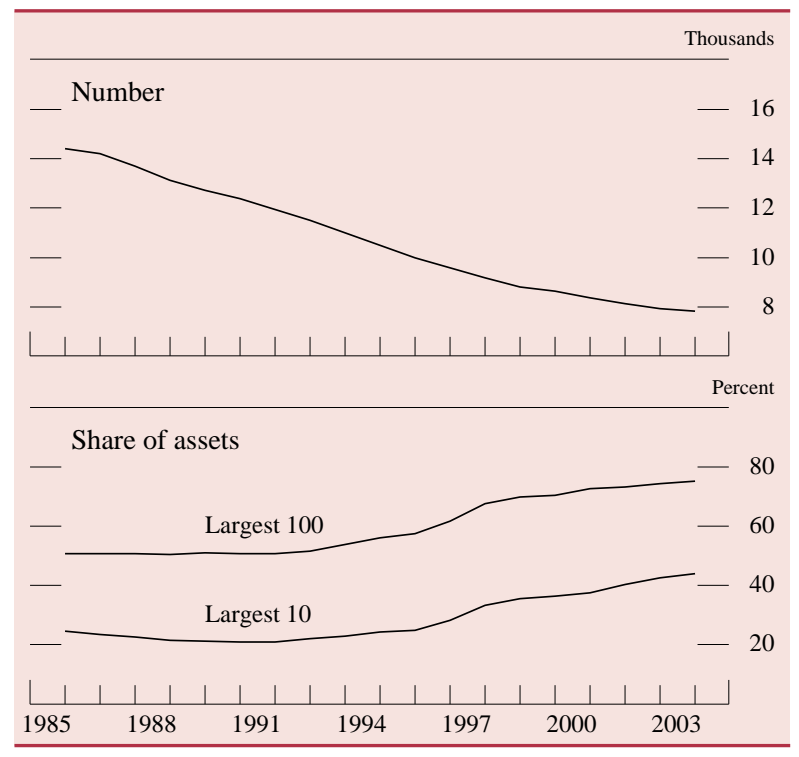

Note. For the definition of bank size, see the text note. 
the 10 largest banks and 100 largest banks both edged up 1 percentage point, to 44 percent and 75 percent respectively.

Mergers were also restrained at the bank holding company (BHC) level. Top-tier BHCs-that is, BHCs that are not a subsidiary of another BHC-increased by 17 , to 5,152: The number of newly formed BHCs slightly exceeded the number of mergers. The share of assets held by the top fifty BHCs was about 73.7 percent. The number of domestic financial holding companies, a subset of BHCs with a greater scope of allowed activities under the Gramm-Leach-Bliley Act, ticked down to 601, and the share of BHC assets held by these financial holding companies moved down to 89.5 percent. $^{2}$

2. The Federal Reserve Board provides quarterly reports on the condition of the banking industry from the perspective of bank hold-

\section{BALANCE SHEET DEVELOPMENTS}

Total bank assets grew 7.2 percent in 2003, about 1 percentage point less than the growth of total domestic nonfinancial debt (table 1 ). ${ }^{3}$ With low mortgage rates and a strong housing market, mortgagebacked securities and residential real estate loans were among the major drivers supporting asset growth. The advances in those components more than compensated for the continued runoff in commercial and industrial loans, which declined for the

ing companies that file report FR Y-9C/FR Y-9LP. Publication of these reports started in the winter 2004 issue of the Federal Reserve Bulletin.

3. The adoption of FASB Interpretation No. 46, or FIN 46, boosted asset growth last year, but the effect was likely less than 1 percentage point (see box "The Effects of FASB FIN 46 on Banks' Balance Sheets")

1. Annual rates of growth of balance sheet items, 1994-2003

Percent

\begin{tabular}{|c|c|c|c|c|c|c|c|c|c|c|c|}
\hline Item & 1994 & 1995 & 1996 & 1997 & 1998 & 1999 & 2000 & 2001 & 2002 & 2003 & $\begin{array}{c}\text { MEMO: } \\
\text { Dec. } \\
2003 \\
\text { (billions } \\
\text { of } \\
\text { dollars) }\end{array}$ \\
\hline Assets $\ldots \ldots \ldots \ldots \ldots$ & 8.06 & 7.57 & 6.10 & 9.23 & 8.26 & 5.44 & 8.75 & 5.12 & 7.20 & 7.20 & 7,456 \\
\hline Interest-earning assets ... & 5.28 & 7.80 & 5.79 & 8.67 & 8.28 & 5.84 & 8.65 & 3.96 & 7.54 & 7.29 & 6,432 \\
\hline Loans and leases (net) $\ldots \ldots \ldots$ & 9.82 & 10.58 & 8.12 & $\begin{array}{l}0.31 \\
5.34\end{array}$ & $\begin{array}{l}0.20 \\
8.89\end{array}$ & 8.04 & $\begin{array}{l}9.03 \\
9.24\end{array}$ & 1.82 & 5.90 & 6.53 & 4,259 \\
\hline Commercial and industrial & 9.34 & 12.25 & 7.24 & 12.02 & 12.94 & 7.88 & 8.54 & -6.73 & -7.29 & -4.56 & 863 \\
\hline Real estate $\ldots \ldots \ldots \ldots \ldots$ & 7.94 & 8.28 & 5.45 & 9.30 & 7.99 & 12.22 & 10.74 & 7.94 & 14.43 & 9.77 & 2,249 \\
\hline Booked in domestic offices & 7.68 & 8.43 & 5.51 & 9.53 & 7.97 & 12.36 & 11.02 & 8.02 & 14.85 & 9.68 & 2,214 \\
\hline $\begin{array}{l}\text { One- to four-family } \\
\text { residential }\end{array}$ & 10.14 & 10.01 & 466 & 967 & 6.36 & 970 & 928 & 570 & 1985 & 10.04 & 1267 \\
\hline $\begin{array}{l}\text { residential ..... } \\
\text { Other ................ }\end{array}$ & $\begin{array}{r}10.14 \\
4.38\end{array}$ & $\begin{array}{r}10.01 \\
6.21\end{array}$ & $\begin{array}{l}4.00 \\
6.75\end{array}$ & $\begin{array}{l}.01 \\
9.32\end{array}$ & $\begin{array}{r}0.30 \\
10.29\end{array}$ & $\begin{array}{r}9.10 \\
16.06\end{array}$ & 13.30 & 10.96 & $\begin{array}{r}19.85 \\
8.81\end{array}$ & $\begin{array}{r}10.04 \\
9.21\end{array}$ & $\begin{array}{l}1,201 \\
946\end{array}$ \\
\hline Booked in foreign offices & 18.35 & 2.81 & 3.18 & .34 & 8.79 & 6.28 & -1.62 & 3.97 & -7.41 & 15.52 & 36 \\
\hline Consumer $\ldots \ldots \ldots \ldots \ldots$ & 15.89 & 9.86 & 4.90 & -2.19 & .99 & -1.47 & 8.05 & 4.17 & 6.58 & 9.33 & 710 \\
\hline Other loans and leases & 5.29 & 14.22 & 22.28 & -7.91 & 13.95 & 6.71 & 6.99 & -2.00 & -.26 & 8.35 & 513 \\
\hline $\begin{array}{l}\text { Loan-loss reserves and } \\
\text { unearned income }\end{array}$ & $-2,27$ & 38 & -06 & -50 & 3.47 & 235 & 7.97 & 13.17 & 574 & -272 & 77 \\
\hline Securities .................. & -4.14 & .56 & -.00 & 8.85 & $\begin{array}{l}3.41 \\
8.40\end{array}$ & 5.11 & 6.33 & $\begin{array}{r}10.17 \\
7.25\end{array}$ & $\begin{array}{r}5.14 \\
16.20\end{array}$ & 9.43 & 1,662 \\
\hline Investment account & -1.73 & -1.58 & -1.10 & 8.66 & 12.06 & 6.68 & 2.82 & 8.91 & 13.54 & 8.70 & 1,422 \\
\hline U.S. Treasury …........... & n.a. & -19.21 & -14.28 & -8.85 & -25.17 & -1.89 & -32.74 & -40.25 & 41.92 & 14.18 & 72 \\
\hline $\begin{array}{l}\text { U.S. government agency and } \\
\text { corporation obligations }\end{array}$ & na & 642 & & & & & & & & & 903 \\
\hline Other .... & $\begin{array}{l}\text { n..a. } \\
\text { n.a. }\end{array}$ & $\begin{array}{l}6.42 \\
4.19\end{array}$ & $\begin{array}{l}3.63 \\
1.83\end{array}$ & $\begin{array}{l}14.18 \\
11.20\end{array}$ & $\begin{array}{l}1.00 \\
26.99\end{array}$ & $\begin{array}{r}1.83 \\
20.90\end{array}$ & $\begin{array}{r}3 . / 1 \\
13.38\end{array}$ & $\begin{array}{l}12.89 \\
12.18\end{array}$ & $\begin{array}{r}18.10 \\
272\end{array}$ & $\begin{array}{l}9.66 \\
5.99\end{array}$ & $\begin{array}{l}903 \\
447\end{array}$ \\
\hline Trading account & -20.46 & 18.51 & 14.44 & 10.00 & -13.32 & -6.93 & 37.16 & -3.72 & 36.02 & 14.03 & 240 \\
\hline Other $\ldots \ldots \ldots \ldots \ldots$ & 3.30 & 8.61 & 1.04 & 38.55 & 3.80 & -8.37 & 10.29 & 13.00 & -2.91 & 6.93 & 511 \\
\hline Non-interest-earning assets .. & 31.62 & 6.05 & 8.28 & 13.03 & 8.12 & 2.90 & 9.44 & 12.81 & 5.11 & 6.60 & 1,024 \\
\hline Liabilities . & 8.31 & 7.20 & 5.96 & 9.12 & 8.14 & 5.58 & 8.58 & 4.46 & 7.13 & 7.25 & 6,781 \\
\hline 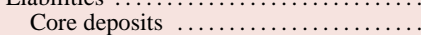 & $\begin{array}{l}0.01 \\
-.15\end{array}$ & 3.94 & 4.13 & 4.52 & $\begin{array}{l}0.14 \\
7.04\end{array}$ & & & 10.55 & 7.58 & 7.12 & 3,666 \\
\hline Transaction deposits $\ldots \ldots \ldots$ & -.31 & -3.11 & -3.44 & -4.55 & -1.41 & -8.98 & -1.31 & 10.20 & -5.12 & 2.19 & 716 \\
\hline Savings and small time deposits & -.06 & 8.35 & 8.35 & 9.04 & 10.73 & 3.80 & 10.54 & 10.66 & 11.42 & 8.39 & 2,949 \\
\hline Managed liabilities ${ }^{1} \ldots \ldots \ldots \ldots$ & 17.53 & 10.56 & 9.66 & 13.84 & 9.64 & 15.54 & 8.77 & -2.71 & 5.36 & 7.24 & 2,605 \\
\hline Deposits booked in foreign & & & & & & & & & & & \\
\hline offic & 30.89 & 5.13 & 4.27 & 11.13 & 8.71 & 14.60 & 7.79 & -10.92 & 4.49 & 12.63 & 741 \\
\hline Large time ................. & 8.73 & 19.60 & 21.17 & 20.15 & 9.09 & 14.19 & 19.37 & -3.65 & 5.05 & 1.43 & 579 \\
\hline Subordinated notes and & & & & & & & & & & & \\
\hline $\begin{array}{r}\text { deben } \\
\text { Other man: }\end{array}$ & $\begin{array}{r}9.23 \\
12.80\end{array}$ & $\begin{array}{r}6.61 \\
11.52\end{array}$ & $\begin{array}{r}17.74 \\
8.21\end{array}$ & $\begin{array}{l}21.05 \\
12.23\end{array}$ & $\begin{array}{r}17.00 \\
9.97\end{array}$ & $\begin{array}{r}5.07 \\
17.76\end{array}$ & $\begin{array}{r}13.98 \\
3.89\end{array}$ & $\begin{array}{l}9.56 \\
2.48\end{array}$ & $\begin{array}{l}-.59 \\
6.59\end{array}$ & $\begin{array}{l}5.84 \\
7.15\end{array}$ & $\begin{array}{r}100 \\
1.186\end{array}$ \\
\hline Other ............ & 79.17 & 20.48 & 2.60 & 23.79 & 8.59 & -6.37 & 15.39 & 3.11 & 13.55 & 8.30 & 511 \\
\hline Equity capital & 5.23 & 12.04 & 7.74 & 10.45 & 9.58 & 3.92 & 10.65 & 12.32 & 7.84 & 6.63 & 674 \\
\hline Мемо & & & & & & & & & & & \\
\hline Commercial real estate loans & 4.02 & 6.32 & 7.67 & 10.13 & 11.37 & 15.42 & 12.15 & 13.10 & $\begin{array}{r}6.82 \\
1566\end{array}$ & 9.01 & 944 \\
\hline Mortgage-backed securities & n.a. & .66 & 2.06 & 14.16 & 22.12 & -3.34 & 3.28 & 29.06 & 15.56 & 10.09 & 761 \\
\hline
\end{tabular}

Note. Data are from year-end to year-end.

2. Measured as the sum of construction and land development loans secured

1. Measured as the sum of deposits in foreign offices, large time deposits in domestic offices, federal funds purchased and securities sold under repurchase agreements, demand notes issued to the U.S. Treasury, subordinated notes and debentures, and other borrowed money. by real estate; real estate loans secured by nonfarm nonresidential properties; real estate loans secured by multifamily residential properties; and loans to finance commercial real estate, construction, and land development activities not secured by real estate. 
third straight year as nonfinancial firms relied heavily on capital markets and internal funds to finance their activities. Overall, total loans and leases increased 6.5 percent, and securities expanded 9.4 percent.

On the liability side of the balance sheet, banks were again able to attract strong inflows of core deposits, especially into savings and money market deposit accounts, because banks reduced deposit rates less than money market yields declined; consequently, the opportunity costs for households of holding liquid deposits fell further. Nonetheless, banks also had to increase their managed liabilities to finance asset growth.

Banks continued to add to their capital in 2003, and their overall capital positions remained robust. While equity capital increased somewhat more slowly than assets did, risk-based regulatory capital ratios still edged up a bit, an uptick driven both by a shift in asset composition toward assets with low risk weights—such as government and agency-related mortgage-backed securities and residential real estate loans - and by the brisk expansion of tier 1 capital.

\section{Loans to Businesses}

Commercial and industrial (C\&I) loans declined 4.6 percent in 2003, a fair bit less than in 2001 and $2002 .{ }^{4}$ Issuance of bonds, particularly those rated below investment grade, was strong last year, as low interest rates and declining risk spreads offered corporations the opportunity to lock in low-cost longterm financing. The proceeds were used, in part, to pay down short-term obligations, including $\mathrm{C} \& \mathrm{I}$ loans. Because the customers of large banks are more likely to be large corporations with access to bond markets, the erosion in C\&I lending was concentrated at large banks (those ranked in the top 100 in terms of assets, which account for about three-fourths of total C\&I loans). At smaller banks, on a mergeradjusted basis, commercial loan portfolios actually expanded, although their growth was about flat before adjustment.

The improved profitability of nonfinancial firms also damped loan demand, as substantial gains in profits outpaced the growth of firms' capital expenditures; consequently, the financing gap-the difference between investment outlays and internally generated funds-fell and became negative in 2003 (chart 4). A boost in inventory spending by nonfinan-

4. For a more detailed analysis of recent trends in C\&I lending, see William Bassett and Egon Zakrajšek, "Recent Developments in Business Lending by Commercial Banks," Federal Reserve Bulletin, vol. 89 (December 2003), pp. 477-92.
4. Financing gap at nonfarm nonfinancial corporations, 1991-2003

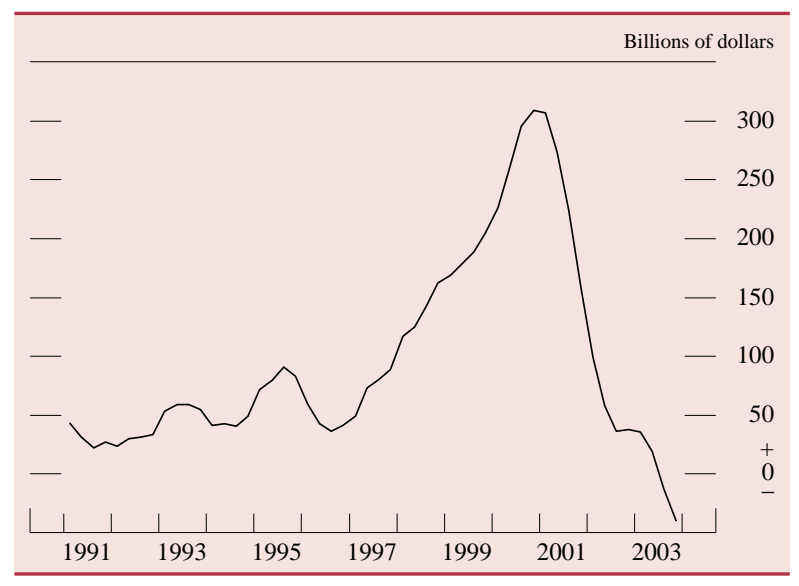

NOTE. The data are four-quarter moving averages. The financing gap is the difference between capital expenditures and internally generated funds.

SourCE. Federal Reserve Board, Statistical Release Z.1, "Flow of Funds Accounts of the United States," table F. 102 (www.federalreserve.gov/ releases/z1).

cial firms late last year, however, likely helped limit the contraction in business loans.

Responses to the Senior Loan Officer Opinion Survey on Bank Lending Practices (BLPS) also suggest that the drop in aggregate business loans resulted primarily from decreased demand. Survey responses, especially early in the year, often pointed to weak investment and inventory spending by businesses and to the shift to other forms of financing as factors explaining the drop in C\&I loans. However, the margin by which respondent banks reporting decreases in demand exceeded those reporting increases in demand diminished over 2003, and a small net fraction reported stronger demand in the January 2004 BLPS (chart 5, top panel). According to respondent banks, the strengthening of demand was spurred by spending on plant and equipment and by increased funding needs to finance accounts receivable and inventories.

Supply conditions apparently played only a secondary role in the weakness of C\&I loans. In the first part of 2003, banks reported tightening both standards and terms somewhat; but by the end of the year, a substantial net fraction of respondents had begun easing terms, and in the January 2004 BLPS a significant net fraction reported easier standards (chart 5, bottom panel). The reasons cited most often for the increased willingness to lend were more-aggressive competition from other banks and nonbanks and an improved economic outlook. According to the Survey of Terms of Business Lending (STBL), banks also appeared to perceive a reduction in the risk of their C\&I borrowers for most of the year, a pos- 
5. Supply and demand conditions for C\&I loans at selected banks, large and medium-sized borrowers, 1999:Q1-2004:Q1

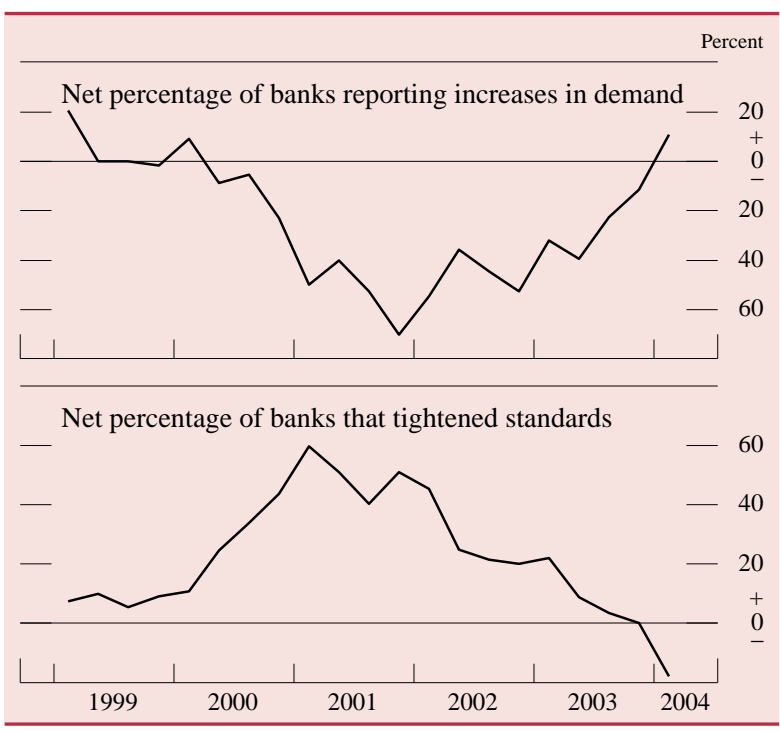

Note. Data are quarterly. Net percentage is the percentage of banks reporting an increase in demand or a tightening of standards less, in each case, the percentage reporting the opposite. The definition for firm size suggested for, and generally used by, survey respondents is that large and medium-sized firms have sales greater than $\$ 50$ million.

SourCE. Federal Reserve Board, "Senior Loan Officer Opinion Survey on Bank Lending Practices."

sible sign of banks' increasingly positive assessment of economic prospects. The shift may also have reflected banks' reduced willingness to lend to riskier customers. Supporting this interpretation, the trend toward lower loan risk ratings was partially reversed in the February 2004 STBL as some banks were easing lending standards.

Unlike C\&I loans, commercial real estate (CRE) loans continued to expand solidly in 2003. Growth in loans secured by nonfarm nonresidential properties was only slightly lower than in 2002. Despite persistent high vacancy rates and declining rates in the market for office rentals, growth of loans for construction and land development nearly doubled last year. Growth in the other components of CRE lending-including loans secured by multifamily properties and by farmland-remained brisk at about the same pace as that of the previous year. As has been the pattern for the past several years, CRE loans grew much faster at smaller banks: At the top 100 banks, such loans grew only 2.6 percent; at banks ranked outside the top 100, they expanded more than 16 percent. At the end of 2003, as a result, smaller banks held more total CRE loans in aggregate than did larger banks.

According to responses to the BLPS, which surveys mainly large banks, changes in both the demand
6. Supply and demand conditions for commercial real estate loans at selected banks, 1999:Q1-2004:Q1

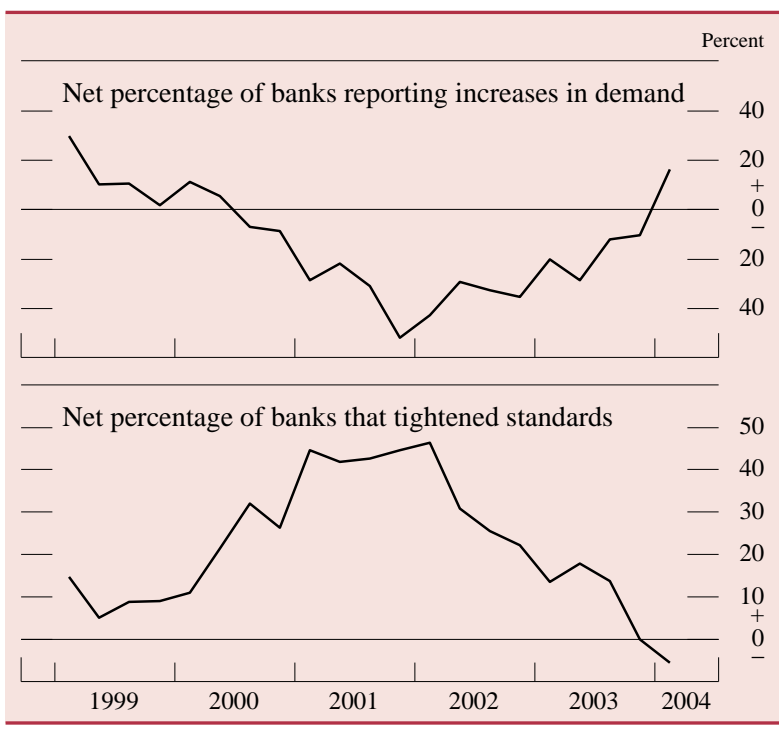

NotE. See notes to chart 5 .

Source. Federal Reserve Board, "Senior Loan Officer Opinion Survey on Bank Lending Practices."

for and the supply of CRE loans improved in 2003. In a pattern similar to that for C\&I loans, the net percentages of banks reporting an increase in demand and an easing of lending standards on CRE loans turned positive in the January 2004 BLPS (chart 6). Also, some banks-about 20 percent of the respondents, on net-increased the maximum size of the CRE loans that they were willing to extend during 2003, according to responses to a special question in the January 2004 BLPS. A similar percentage indicated that they became willing to provide CRE loans with longer maturities. As was the case for $\mathrm{C} \& \mathrm{I}$ loans, the most frequently cited reasons for easing terms were more-aggressive competition from other commercial banks or nonbank lenders and improved conditions in, and outlook for, the commercial real estate market.

\section{Loans to Households}

Lending to households grew rapidly in 2003; the strong pace reflected robust consumer spending, the high level of housing activity, and a surge of mortgage refinancing that occurred in the first half of the year caused by a drop in long-term interest rates. Indeed, the Mortgage Bankers Association's index of refinancing activity rose at midyear to levels even higher than the peaks seen in 2001 and 2002 (chart 7). In this environment, banks continued to briskly expand both their revolving home equity and 
7. Index of home mortgage refinancing activity, 1991-2003

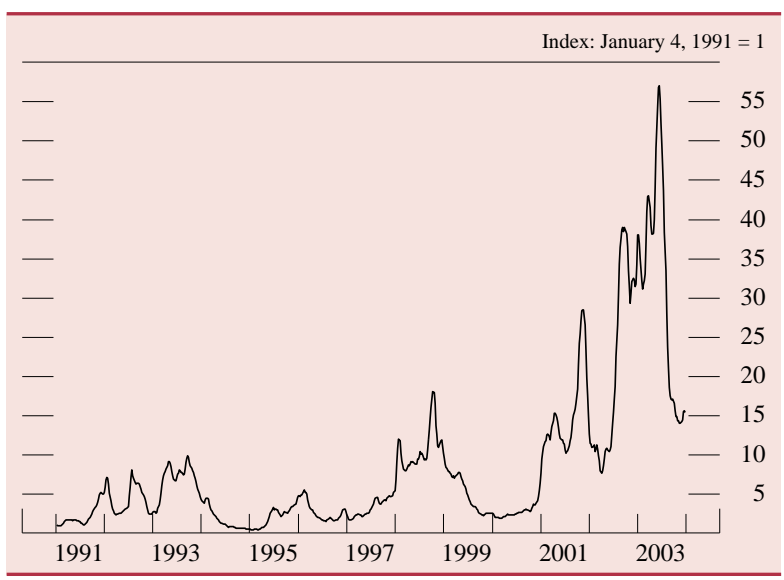

Note. Data are weekly.

SourCE. Mortgage Bankers Association.

their other one- to four-family mortgage lending in the first two quarters of 2003.

As bond yields and mortgage rates rebounded sharply starting in mid-June, however, the demand for one- to four-family mortgages appeared to decline, consistent with responses to the October 2003 and January 2004 BLPSs (chart 8). Given the continued brisk pace of home sales, however, much of the fall in reported demand presumably reflected the drop-off in refinancing rather than a decline in the demand for mortgages to purchase homes. But because of the decline of mortgage originations from their previous record pace and the resulting reduction in mortgage loans temporarily held for later sale in

8. Net percentage of selected banks reporting stronger demand for residential mortgages, 1990:Q4-2004:Q1

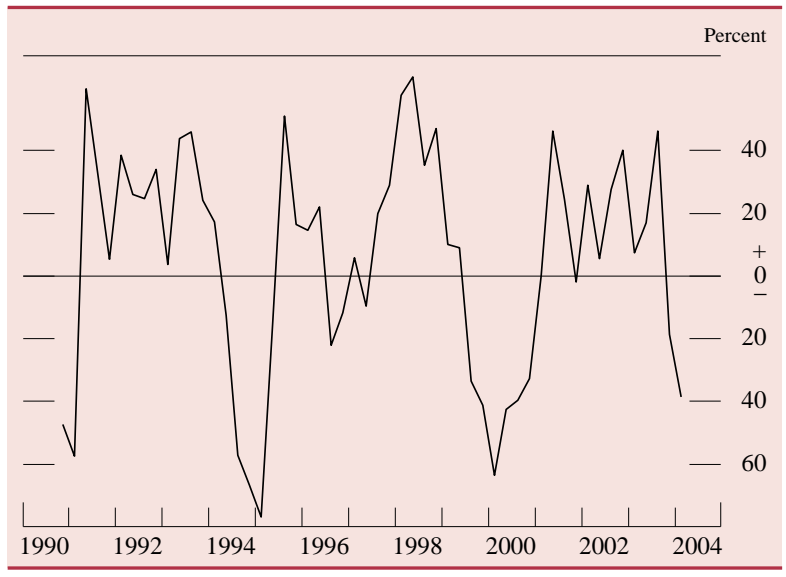

Note. Data are quarterly. Net percentage is the percentage of banks that reported stronger demand less the percentage that reported weaker demand.

Source. Federal Reserve Board, "Senior Loan Officer Opinion Survey on Bank Lending Practices." the secondary market, residential mortgage loans on banks' balance sheets actually contracted in the fourth quarter. Revolving home equity loans, however, continued to grow swiftly. One reason for their rapid growth was the sustained increase in residential real estate values. Another possible reason is that most home equity loans carry variable interest ratestied to short-term rates - that remained very low last year and even declined a bit in the second half after the easing of monetary policy in June. On net, total residential mortgage loans on banks' books expanded 10 percent in 2003. As in 2002, the expansion was accompanied by a reduction of close to 19 percent in the volume of residential mortgages securitized or sold, but for which banks retained servicing rights or provided credit enhancements. Because banks do not report securitized loans for which they provide neither servicing rights nor credit enhancements, a portion of the decline in reported securitizations may simply reflect a relative increase in loans securitized without recourse.

9. Net percentage of selected banks tightening standards for consumer lending, 1996:Q1-2004:Q1

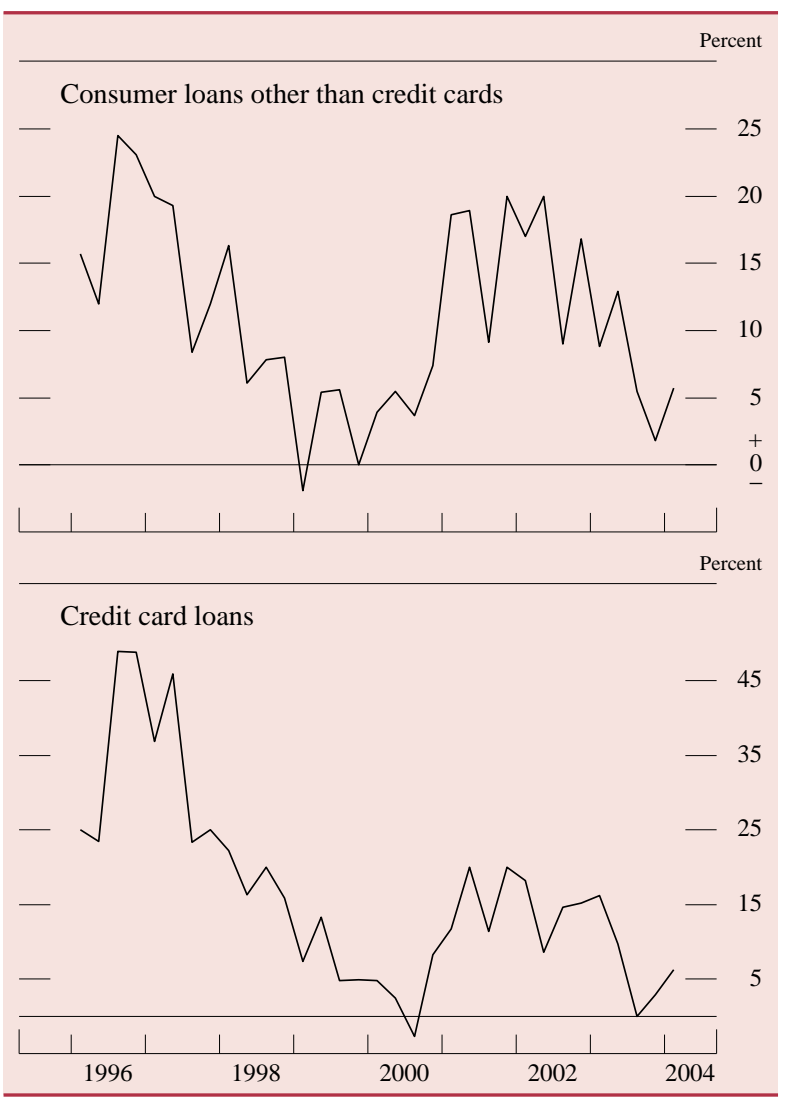

NoTE. Data are quarterly. Net percentage is the percentage of banks that reported tighter standards less the percentage that reported easier standards.

Source. Federal Reserve Board, "Senior Loan Officer Opinion Survey on Bank Lending Practices." 
Many households that refinanced mortgages reportedly cashed out some of the equity in their homes. The proceeds were likely used, at least in part, to pay down higher-cost consumer debt and to fund purchases of durable goods. Consumer loans rose 9.3 percent for the year; however, that aggretate rate was boosted significantly by a large bank's purchase of a sizable credit card portfolio from a nonbank financial institution. Excluding that transaction, the expansion in consumer loans on banks' books, at about 5 percent, was fairly modest given the robust pace of consumer spending last year. Besides paydowns from cash-out refinancing, the brisk expansion in consumer loans that were securitized-mostly credit card receivables - and for which banks retained servicing rights or provided credit enhancements may have restrained the growth rate.

As with businesses, banks maintained a cautious lending posture toward households in 2003. Responses to the BLPS showed that the net percentage of banks that reported tightening standards for all types of consumer loans was never negative during the year (chart 9). This increased watchfulness likely contributed to the restrained growth in consumer loans last year and probably to the drop in consumer loan delinquency rates. Although banks eased consumer loan terms in the first part of the year, the October 2003 and January 2004 BLPS indicated that they subsequently tightened them.

\section{Other Loans and Leases}

Other loans and leases reported on banks' balance sheets grew 8.4 percent in 2003. Much of the increase, however, was apparently attributable to the new reporting requirements under FIN 46, as many of the assets previously held off balance sheet in variable-interest entities that were consolidated onto banks balance sheets during 2003 were classified in the "other loans" category (see box "The Effects of FASB FIN 46 on Banks' Balance Sheets").

\section{The Effects of FASB FIN 46 on Banks' Balance Sheets}

In January 2003, the U.S. Financial Accounting Standards Board (FASB) issued Interpretation No. 46, "Consolidation of Variable Interest Entities," or FIN 46. Under this interpretation, business enterprises, including banks, must consolidate onto their balance sheets the assets and liabilities of certain variable-interest entities (VIEs). VIEs are legal entities that are usually created for a specific purpose, such as securitizing assets. For example, banks commonly sponsor asset-backed commercial paper conduits, which purchase assets from several corporations and then issue to investors commercial paper backed by those assets.

Under the rules in effect before FIN 46, consolidation was generally determined by majority voting control. It is possible, however, for the sponsor to be exposed to the risk and return associated with a VIE without having majority voting control. In an effort to remedy the perceived deficiency in reporting such exposures, FIN 46 requires a company to consolidate the assets and liabilities of any VIE of which it is deemed to be the "primary beneficiary." The primary beneficiary of a VIE is the one that absorbs a majority of the entity's expected losses, if they occur; receives a majority of the expected residual returns, if they occur; or both. The primary beneficiary need not have majority voting control of the VIE. Also, a company must disclose, although not consolidate, VIEs in which it has a significant variable interest. For the purposes of FIN 46, a variable interest is defined as an interest that is subject to and fluctuates with the VIE's net asset value. Examples include equity as well as various types of derivatives, senior beneficial interests, variable service contracts, and leases.
When first released, FIN 46 was scheduled to take effect for most U.S. companies no later than the beginning of the first interim or annual reporting period that started after June 15, 2003. The rule was later amended, and its required adoption was pushed to the close of the first reporting period ending after December 15, 2003. ${ }^{1}$ Most large U.S. banks implemented the new rule by the end of 2003. Most small banks are not affected because they do not commonly have interests in VIEs.

The effects of FIN 46 on banks' balance sheets can be estimated from the weekly bank credit data collected by the Federal Reserve and the remarks provided by individual banks on unusual weekly changes in bank credit components. These estimates suggest that, by year-end 2003, U.S. banks had consolidated roughly $\$ 67$ billion in assets-less than 1 percent of total assets-that previously had not been reported on balance sheet. The majority of that amountabout $\$ 42$ billion-was included in the "other loans" category and provided a noticeable boost to that balance sheet component. Another $\$ 17$ billion was included in the "securities" category, an amount that equaled about 1 percent of investment and trading account securities on banks' books. Assets were also consolidated under the "C\&I loans" category (about $\$ 7$ billion, less than 1 percent of total C\&I loans) and a small amount under "consumer loans." On the liability side, the vast majority of consolidation was in the "other borrowing" category.

1. On December 23, 2003, FASB issued interpretation FIN 46-R, a revision of FIN 46, that clarified some of its provisions, exempted certain entities from its requirements, and reduced the value of VIE assets and liabilities to be consolidated. 
While loans to other depository institutions and to states and other political subdivisions increased, lease financing receivables declined for the second straight year. Since many leases are made to businesses, the weak performance was likely attributable, in part, to some of the same factors that depressed C\&I loans.

\section{Securities}

Securities held on banks' balance sheets expanded strongly in 2003. At 9.4 percent, the growth rate was less than the extraordinary 16.2 percent of 2002 , but it was still the second-highest in the past ten years. Securities in both investment accounts and trading accounts expanded briskly. As a share of total bank assets, securities continued to increase; the rise is an extension of a trend initiated in 2001 (chart 10).

Mortgage-backed securities (MBS) held in investment accounts posted a solid advance-in excess of 10 percent-for the third consecutive year, and Treasury and non-mortgage-backed agency securities grew even faster. Banks accumulated MBS at a particularly rapid rate in the first half of the year, as interest rates declined and refinancing picked up. When long-term rates rose sharply in the summer, however, and the pace of refinancing slowed, banks responded by paring back their MBS positions considerably, and securities reported on their balance sheets actually contracted for the first time since the first quarter of 2001. Growth in banks' securities holdings resumed, however, as rates stabilized in the fall.

10. Bank holdings of securities as a share of total bank assets, 1991-2003

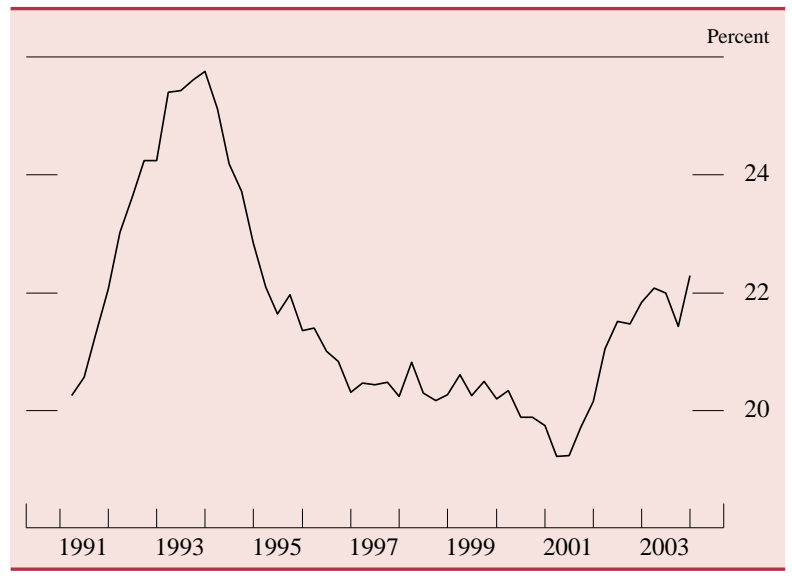

Note. Data are quarterly.

\section{Liabilities}

Core deposits increased 7.1 percent in 2003. Banks reduced the rates they paid on savings and money market deposit accounts by less than the decline in money market yields. As a result, those liquid deposits grew substantially, rising to more than 38 percent of total domestic liabilities by the end of the year (chart 11). By contrast, yields on small time deposits dropped more sharply than those on liquid deposits last year, a possible factor in the slight acceleration of their ongoing declining trend. Moreover, with market interest rates already low and the stock market recovering from its 2002 trough, some households may have chosen to invest in long-term mutual funds, which experienced strong net inflows last year, rather than locking in the low rates offered by time deposits. Transaction deposits grew a good bit in the first half of the year but then fell in the third quarter as the flows associated with mortgage refinancing slowed substantially; on net, such deposits rose only a bit during the year.

Even with the growth in core deposits, banks expanded their managed liabilities 7.2 percent last year. This increase was especially notable for banks outside the top 100, which experienced stronger growth in assets. Across all banks, deposits booked in foreign offices rose 12.6 percent, while the growth of subordinated notes and debentures, which had been briefly interrupted by a slight contraction the previous year, resumed. Large time deposits edged higher.

11. Selected domestic liabilities at banks as a share of their total domestic liabilities, 1996-2003

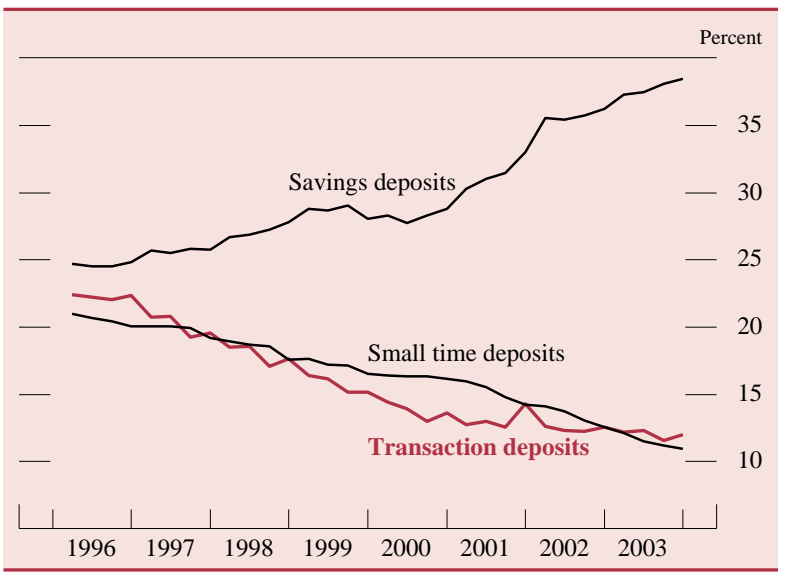

Note. Data are quarterly. Savings deposits include money market deposit accounts. 


\section{Capital}

Banks' capital positions strengthened further in 2003. Equity capital increased 6.6 percent, slightly less than assets. Paid-in capital rose a good bit, in part as a result of mergers; retained earnings grew notably faster in 2003 than in the previous year, a reflection of banks' higher profitability and relatively stable dividend payout ratio. By contrast, accumulated other comprehensive income slumped; the decrease was due to the sharp decline in unrealized gains on available-for-sale securities, which occurred in the second half of the year and was likely induced by the turnaround in long-term interest rates.

Tier 1 capital increased 7.6 percent for the year, while tier 2 capital increased 2.8 percent. Riskweighted assets grew more slowly than total assets, as the growth of assets with low risk weights, such as agency-related MBS, Treasury securities, and residential mortgages, outpaced that of assets with higher risk weights. The tier 1 ratio moved up to just above 10 percent, and the total ratio also rose a bit. The leverage ratio changed little (chart 12). ${ }^{5}$ The share of

5. Tier 1 and tier 2 capital are regulatory measures. Tier 1 capital consists primarily of common equity (excluding intangible assets such as goodwill and excluding net unrealized gains on investment account securities classified as available for sale) and certain perpetual preferred stock. Tier 2 capital consists primarily of subordinated debt, preferred stock not included in tier 1 capital, and loan-loss reserves up to a cap of 1.25 percent of risk-weighted assets. Risk-weighted assets are calculated by multiplying the amount of assets and the credit-equivalent amount of off-balance-sheet items (an estimate of the potential credit exposure posed by the items) by the risk weight for each category. The risk weights rise from 0 to 1 as the credit risk of the assets increases. The tier 1 ratio is the ratio of tier 1 capital to risk-weighted assets; the total ratio is the ratio of the sum of tier 1 and tier 2 capital to risk-weighted assets. The leverage ratio is the ratio of tier 1 capital to average tangible assets. Tangible assets are equal to total assets less assets excluded from common equity in the calculation of tier 1 capital.

\section{Regulatory capital ratios, 1991-2003}

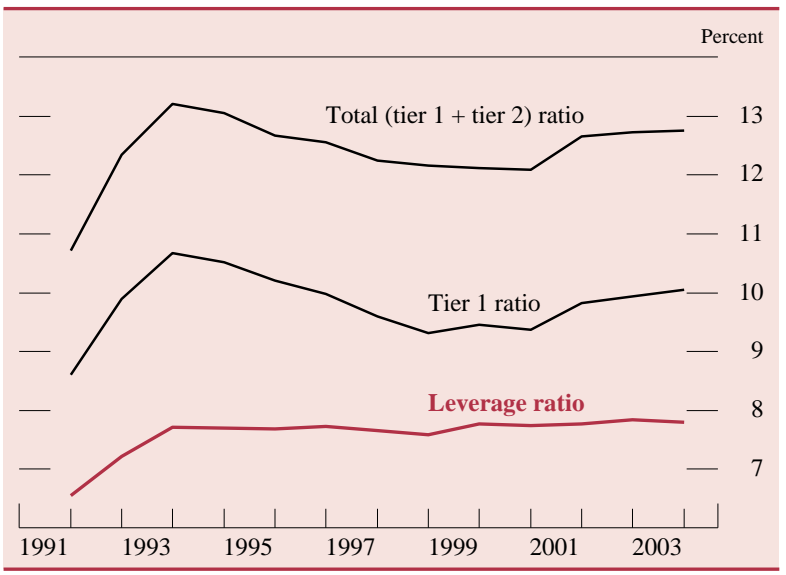

Note. For the components of capital ratios, see text note 5.
13. Assets and regulatory capital at well-capitalized banks, 1991-2003

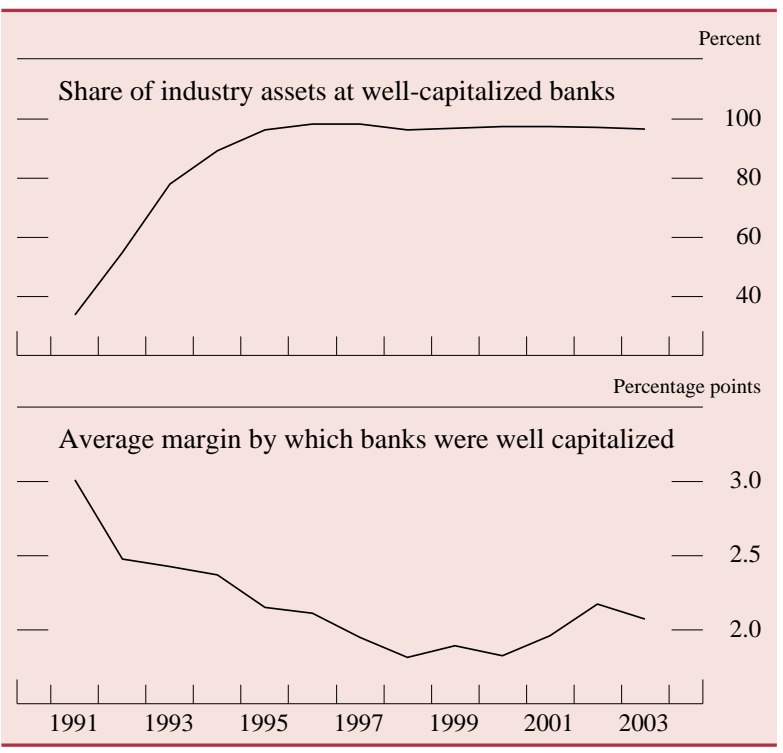

NoTE. For the definitions of "well capitalized" and of the margin by which banks remain well capitalized, see text note 6 .

industry assets held by banks that were considered well capitalized for regulatory purposes was about unchanged and remained near its very high levels of the previous several years. The average margin by which banks were considered well capitalized was substantial, although it edged down a bit from 2002 (chart 13). ${ }^{6}$

\section{Derivatives}

The notional principal amount of derivatives contracts held by banks surged nearly 27 percent in 2003 , to about $\$ 71$ trillion. The market value of a derivatives contract, however, is typically much

6. Well-capitalized banks are those with a total risk-based capital ratio of 10 percent or greater, a tier 1 risk-based ratio of 6 percent or greater, and a leverage ratio of 5 percent or greater. In addition, supervisors can, when appropriate based on safety and soundness considerations, downgrade a bank's capital category from well capitalized. To take account of this possibility, we assume that wellcapitalized banks must have CAMELS ratings of 1 or 2. Each letter in CAMELS stands for a key element of bank financial conditionCapital adequacy, Asset quality, Management, Earnings, Liquidity, and Sensitivity to market risks. The average margin by which banks remained well capitalized was computed as follows. Among the leverage, tier 1, and total capital ratios of each well-capitalized bank, the institution's tightest capital ratio is defined as the one closest to the regulatory standard for being well capitalized. The bank's margin is then defined as the percentage point difference between its tightest capital ratio and the corresponding regulatory standard. The average margin among all well-capitalized banks - the measure referred to in chart 13-is the weighted average of all the individual margins, with the weights being each bank's share of the total assets of wellcapitalized banks. 
smaller than its notional value. Banks enter into derivatives contracts both for their own account (to manage their own market and credit risks) and in their role as dealers. When acting in the second role, banks often enter into at least partially offsetting contracts with different counterparties. Such offsetting transactions appear to constitute a substantial fraction of banks' activities in derivatives. At the end of 2003, the fair market value of contracts with positive value was $\$ 1.173$ trillion, about unchanged from the previous year, and the fair market value of contracts with negative market value was $\$ 1.150$ trillion, slightly more than in 2002. The net fair value was thus $\$ 23$ billion, down about $\$ 4$ billion from the year before. Consistent with previous years, large banks held the bulk of derivatives contracts, with the top ten banks by assets accounting for 96 percent of the total.

Interest rate swaps-agreements in which two parties agree to exchange a stream of floating-interestrate payments for a stream of fixed-interest-rate payments based on a notional principal amount - are the most common derivatives held by banks. The share of interest rate contracts in the total notional principal amount of all bank derivatives contracts climbed to 59 percent in 2003, up more than 4 percentage points from the previous year. Investors often use interest rate swaps to hedge interest rate risk. The growing presence of interest-sensitive assets, particularly MBS and mortgages, in investors' portfolios, along with the volatility of long-term interest rates last summer, may have boosted investor demand for interest rate swaps last year, thereby increasing banks' holdings of those contracts in their role as dealers in that market. Interest rate futures, forwards, and options; foreign exchange derivatives; and equity derivatives accounted for almost 40 percent of the total notional amount of banks' derivatives contracts at the end of 2003.

The remaining derivatives contracts that banks held were credit derivatives-agreements in which the risk of default of a certain reference entity is transferred from one party (the beneficiary) to another (the guarantor). Use of credit derivatives has grown rapidly in recent years, and the notional amount held by banks surged more than 56 percent in 2003, to slightly more than $\$ 1$ trillion. As is the case for other derivatives, however, banks are both buyers and sellers of these contracts. At the end of last year, the notional quantity of banks' positions as beneficiaries amounted to about $\$ 530$ billion, and their positions as guarantors totaled about $\$ 471$ billion. On net, therefore, banks were recipients of credit protection, as they have typically been in the past. Like other derivatives, the market for credit derivatives is dominated by the largest institutions, with the top ten banks by assets holding almost 96 percent of the total notional amount outstanding. However, the share held by banks outside the top ten, while still quite small, nearly doubled in 2003; on balance, those banks are also net receivers of credit protection.

\section{TRENDS IN PROFITABILITY}

The banking industry continued to be very profitable in 2003. Bank's return on assets rose to 1.40 percent, surpassing last year's record. Return on equity (ROE) increased to 15.3 percent, up about 90 basis points from the previous year. Profitability was especially strong at the ten largest banks, where ROE jumped 2.8 percentage points, to 16 percent, the highest level since 1993. While the largest banks stood out, banks of all sizes posted high returns. The proportion of banks with negative net income declined for the second consecutive year, to 6 percent, and these banks held only 0.7 percent of industry assets, the lowest share since 1997.

The improvement in profitability last year reflected a reduction in expenses and an increase in some income items. Better credit quality-which was due in part to low interest rates, the strengthening economy, and improved corporate profitability—allowed banks to substantially reduce loss provisioning. The reduction in loss provisioning was most pronounced at the ten largest banks, where it had increased the most in recent years, and contributed significantly to their exceptional performance last year. Non-interest expense grew at a moderate pace as banks held down the growth of non-salary-related expenses. Non-interest income rose at its fastest rate since 1999 because of increased earnings from the sale and securitization of loans as well as from fees for fiduciary and investment banking services. Realized gains on securities continued to boost income, particularly as medium-term and long-term interest rates fell in the first half of the year. Profitability was restrained, however, by a further narrowing of net interest margins.

Bank profitability was notably affected in 2003 by the wave of debt refinancing by households and businesses that resulted from the decline in long-term interest rates. Fees associated with the origination, sale, and servicing of refinanced residential mortgages bolstered banks' non-interest income. Underwriting income increased as businesses issued bonds to lock in long-term financing at favorable rates and to pay down C\&I loans and other short-term debt. 
14. Indexes of bank stock prices and the S\&P 500, 2001-March 2004

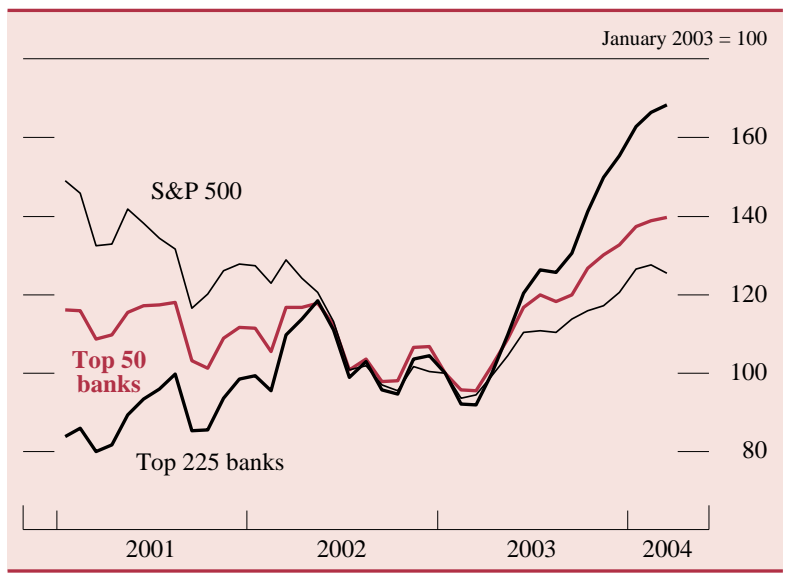

NoTE. Data are monthly. Banks are ranked by market value, and stock prices are weighted by market value.

Source. Standard \& Poor's and American Banker.

The resultant strengthening of household and business balance sheets contributed to marked declines in delinquency and charge-off rates and loan-loss provisioning. At the same time, however, the lowered interest payments on residential mortgages and lost earnings on paid-off C\&I loans held down banks' interest income and contributed to the narrowing of net interest margins.

Robust earnings allowed dividend payments, made primarily to parent holding companies, to grow at double-digit rates for the second consecutive year even as dividends were little changed as a share of net income. As noted earlier, however, retained earnings also grew rapidly and boosted equity capital.

15. Average subordinated debt spread at selected bank holding companies, 1999:Q1-2004:Q1

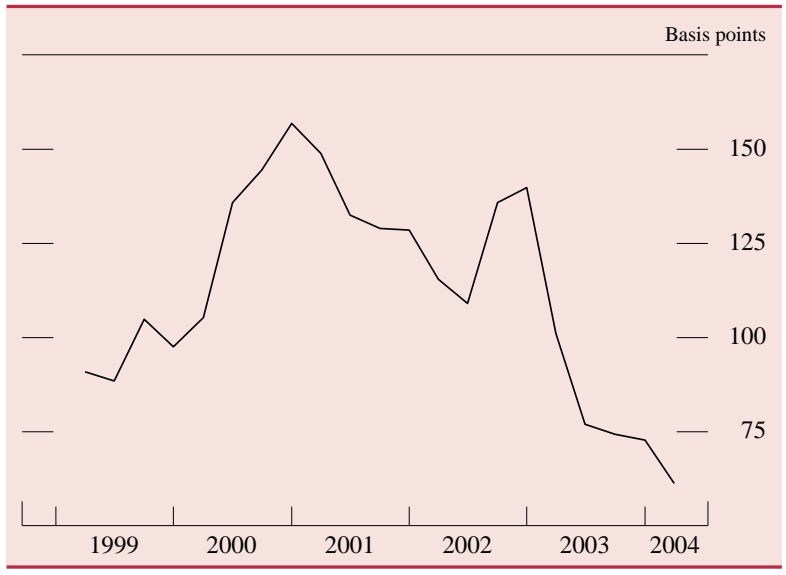

Note. Data are quarterly. Spreads are for twelve large bank holding companies and are weighted by 2003:Q4 assets. Spreads are over comparable Treasury securities.

SOURCE. Merrill Lynch bond data.
With the strong profitability, bank holding company stocks considerably outperformed the S\&P 500 during 2003 (chart 14). Subordinated debt spreads of the largest banks, which had risen in 2002 because of concerns about large banks' exposure to major corporate bankruptcies, narrowed markedly in 2003 and ended the year at quite low levels (chart 15).

\section{Interest Income and Expense}

The fall in the average rate earned on banks' assets exceeded the decline in the average rate paid on their liabilities last year, and net interest margins narrowed further. At about 3.8 percent, the industry net interest margin-defined as net interest income as a percentage of interest-earning assets-reached its lowest level in more than a decade (chart 16). However, the downward slide in net interest margins, which began in the first quarter of 2002, reversed a little during the final quarter of 2003 with the rise in market interest rates.

The declines in rates earned by banks were most pronounced for household assets, a reflection of the heightened pace of mortgage refinancing. Besides depressing yields on residential mortgages and on MBS, cash-out refinancing and home equity borrowing enabled households to pay down some higheryielding consumer loans. Rates earned on credit card loans moved down less than those on other consumer loans, possibly as contractual interest-rate floors on these loans became binding. As a result, banks that specialized in credit card loans had smaller declines in their net interest margins than did other banks during 2003, and their profitability increased by more than that of the industry as a whole. Credit card

\section{Net interest margin, for all banks, 1985-2003}

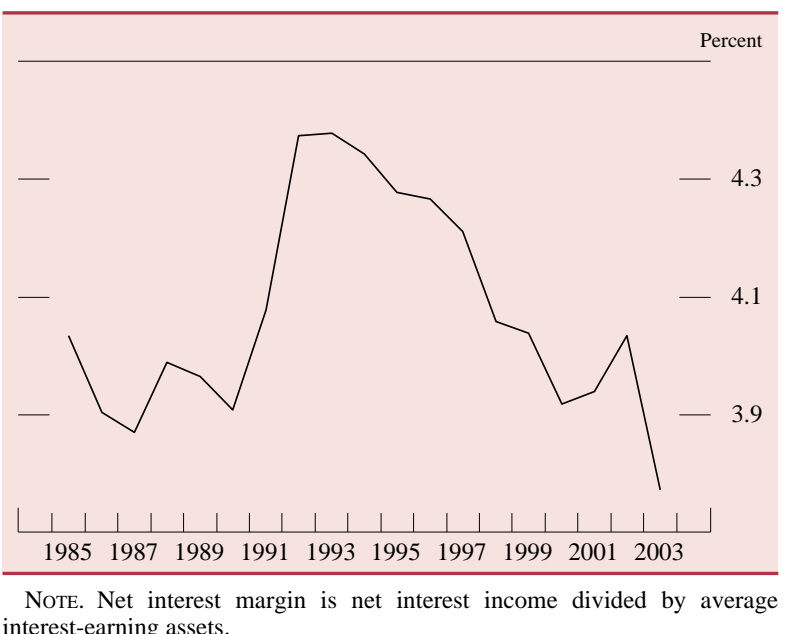




\section{The Role of Non-Interest-Bearing Instruments in the Net Interest Margin}

For most of the past fifteen years, the net interest margin has moved fairly closely with the slope of the yield curve (chart A), a relationship that reflects banks' intermediation across maturities. The recent decline in the net interest margin while the yield curve has remained steep represents a substantial divergence from this pattern.

To help understand this development, we decompose the net interest margin into two parts (figure). One component is the spread between the average return on bank assets and the average rate paid on interest-bearing liabilities times the share of interest-earning assets funded by these liabilities. The second component is the average rate on assets times the share of assets funded with non-interest-bearing liabilities and capital (calculated as 1 minus the share of interestearning assets funded by interest-bearing liabilities). The second component depends on the level of the return on bank assets rather than the spread between the average rate on assets and the average rate on liabilities since noninterest-bearing instruments, by definition, have no explicit interest expense. Last year, about 15 percent of interestearning assets were funded with non-interest-bearing instruments. ${ }^{1}$

The sharp decline in interest rates to historically low levels over the past few years reduced the contribution of the second component to the net interest margin (chart B). This decrease accounted for slightly less than half of the reduction in the net interest margin in 2003 and has accounted for a somewhat larger fraction of the decline since the end of 2001. Although the first component decreased between 2002 and 2003, it remained above its level in the late 1990s, when the yield curve was significantly flatter. Thus, the recent decline in the net interest margin reflected importantly the decline in the level of interest rates, whereas the steep yield curve continued to support the net interest margin.

1. While the separation of the net interest margin into these two components provides some useful insights about the importance of the level of interest rates and banks' funding mix, it describes only one facet of a bank's overall interest rate sensitivity. Perhaps especially when interest rates are very low, banks' earnings can be affected by balance sheet shifts, including shifts in the composition of funding.
A. Net interest margin and the slope of the yield curve, 1989-2003

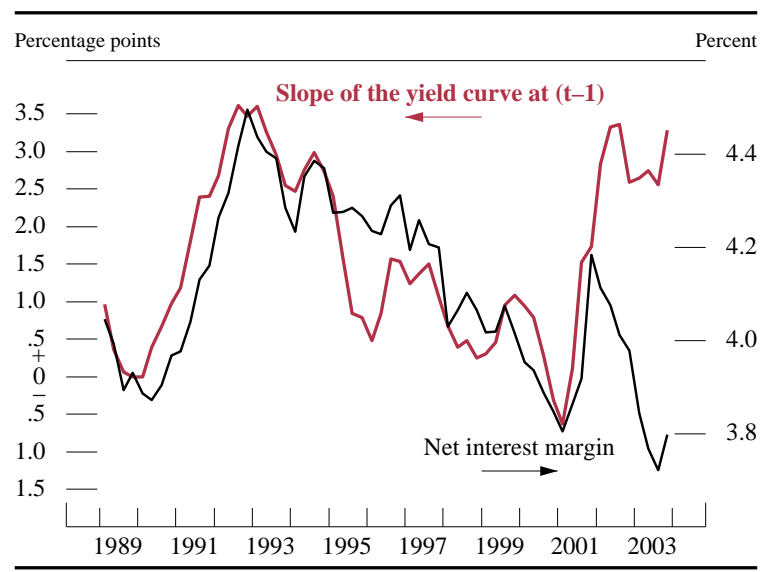

NoTE. Data are quarterly. The net interest margin is net interest income as a share of average interest-earning assets. The slope of the yield curve is the difference between the average ten-year Treasury yield and the three-month bill yield. The slope of the yield curve is lagged one quarter.

Source. Call Report and Federal Reserve Board, Statistical Release H.15, "Selected Interest Rates" (www.federalreserve.gov/releases/h15).

B. Components of net interest margin, 1997-2003

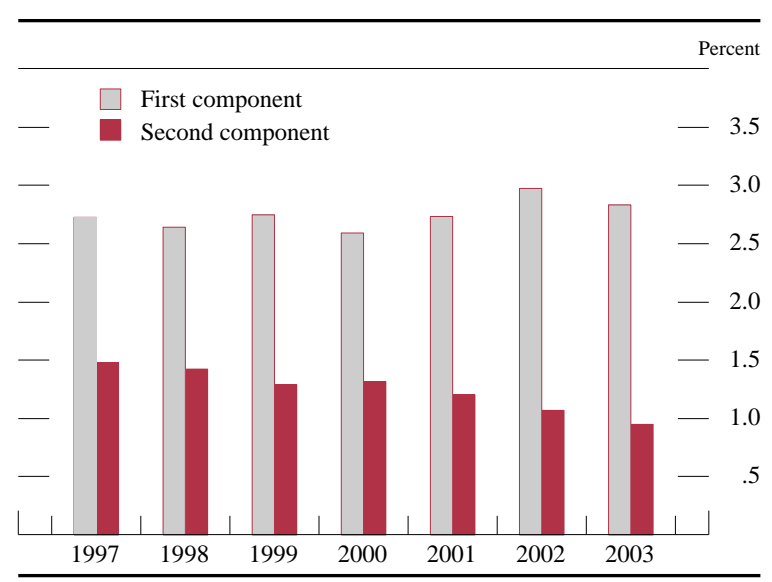

Note. Data are annual. The sum of the two components is the net interest margin.

\section{Decomposition of the net interest margin}

$$
\begin{aligned}
\text { Net interest margin }= & \frac{\text { net interest income }}{\text { interest-earning assets }} \\
= & (\text { rate earned }- \text { rate paid }) \times\left[\frac{\text { interest-bearing liabilities }}{\text { interest-earning assets }}\right] \\
& + \text { First component } \\
& + \text { (rate earned }) \times\left[1-\frac{\text { interest-bearing liabilities }}{\text { interest-earning assets }]}\right. \\
& \text { Second component }
\end{aligned}
$$


lending also played a role in raising net interest margins for the industry during the fourth quarter. Not only did the rate of return on these loans pick up, but also the share of bank assets accounted for by these loans rose, an increase that was due largely to the purchase of a nonbank's credit card portfolio. Also helping to boost net interest margins during the fourth quarter was some recovery in the yield on MBS, which reflected the rise in mortgage rates and the reduced pace of refinancing. ${ }^{7}$

Banks were asked on the August BLPS what policies with respect to their C\&I loans they had adopted in response to the pressure on their net interest margins. More than 60 percent of the survey panel indicated that they had increased fees for these loans, a factor that may have contributed to the rise in non-interest income last year. Another 45 percent of respondents indicated that they had made increased use of interest rate floors, which would restrain the decline in rates earned on variable rate loans. Nevertheless, the effect of such floors appears to have been limited. About 90 percent of respondents indicated that fewer than 15 percent of their C\&I loans had interest rate floors. Furthermore, almost 70 percent of banks reported that, despite the low level of interest rates, the floors were binding for less than 20 percent of the loans having them.

The smaller reduction in average rates paid on liabilities relative to the average rate earned on assets last year reflected in part the sluggish adjustment of rates paid on interest-bearing liquid deposits, which includes interest-bearing checkable deposits, savings deposits, and money market deposit accounts. With rates on these deposits already quite low, banks may have been hesitant to push them further toward zero, especially at a time when assets were growing briskly. Partly countering this tendency for average deposit rates to decline slowly was a substitution of liquid deposits, which expanded rapidly, for higherrate small time deposits, which ran off. Net interest margins were also held down because low interest rates reduced the funding advantage offered by noninterest-bearing funding instruments (See box "The Role of Non-Interest-Bearing Instruments in Net Interest Margins.")

7. The increase in the rate of return on MBS in the fourth quarter in response to the rise in interest rates reflects in part the way in which banks record income related to their securities. Banks are required to amortize premiums paid for MBS over the expected life of the securities and deduct this amount from interest income. The rise in mortgage rates during the latter part of the year increased the expected life of these securities, which lengthened the amortization period and reduced the amount to be deducted.

\section{Non-interest Income and Expense}

Non-interest income increased to a record 44 percent of total revenue in 2003, up from 42 percent during the preceding year (chart 17). Important contributors were gains from the sales of loans, especially during the third quarter, and a rise in securitization activity, both of which were likely related to new residential mortgages created by the surge in refinancing last summer. Non-interest income also benefited from investment banking activities as fees and commissions from underwriting securities grew smartly in 2003, presumably in part because of strong corporate bond issuance. Fiduciary income expanded during the year, although not as fast as total revenue. Fiduciary income advanced mainly during the second and fourth quarters, periods coinciding with large gains in equity prices that likely boosted the value of assets held in bank trusts. Trading income also increased in 2003, a rise that probably reflected in part banks' burgeoning derivatives activities. Deposit fee income continued to grow in 2003, but the rate of expansion was a bit slower than during previous years despite the rapid growth of deposits. Indeed, the ratio of fees to deposits, which had previously risen or held about

\section{Income items as a share of revenue, 1985-2003}

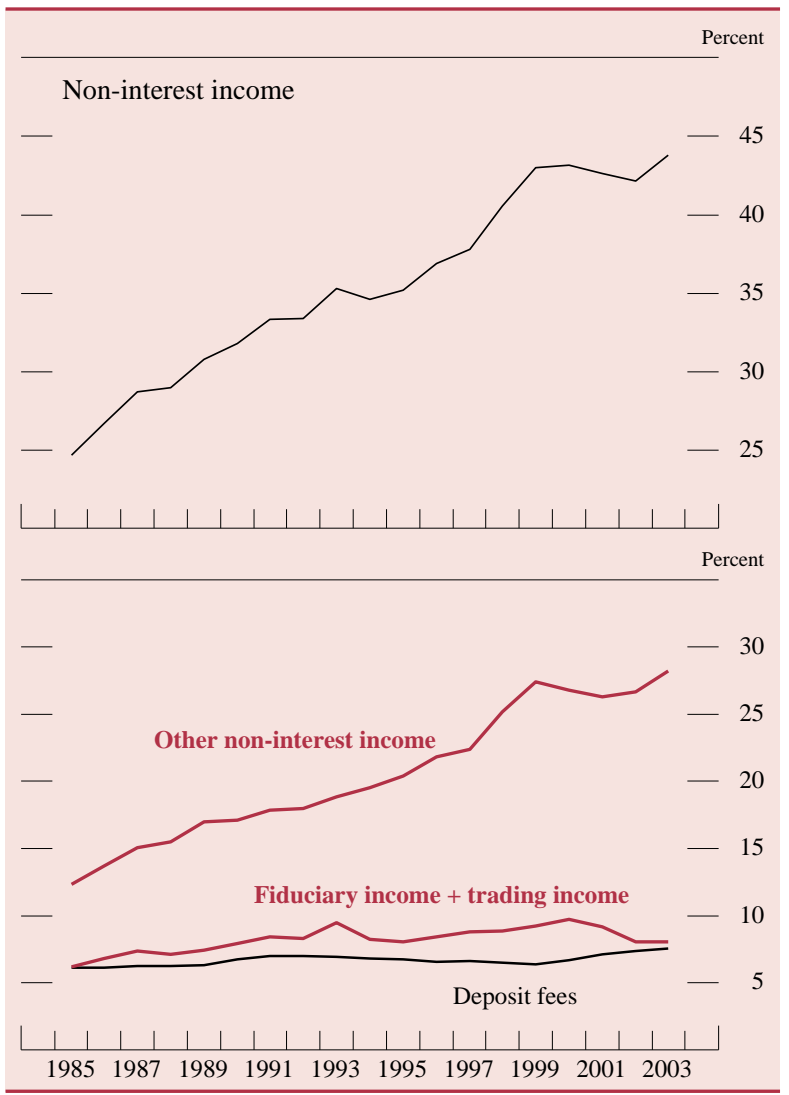


18. Ratio of deposit fee income to total domestic deposits, 1985-2003

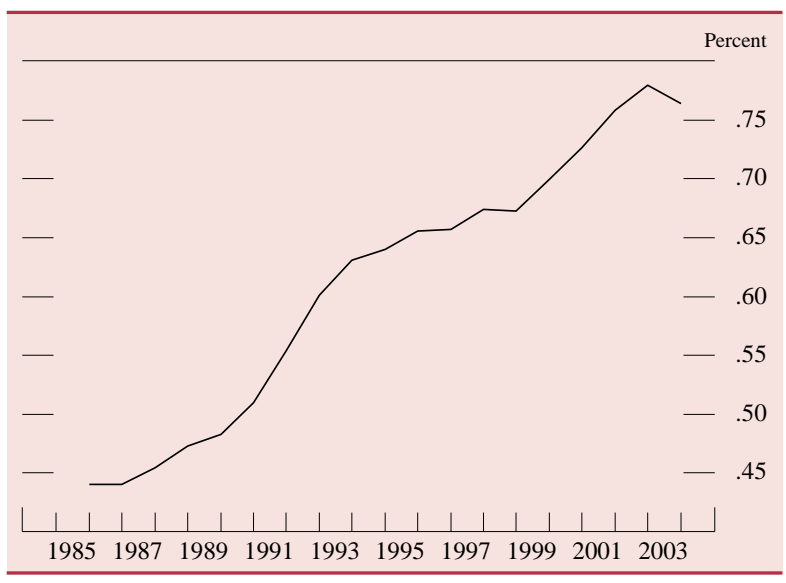

steady in every year during the past two decades, dropped back somewhat in 2003 (chart 18).

Non-interest expense grew moderately during 2003 and ticked up slightly relative to total revenue, a partial reversal of the sharp decline of the previous year (chart 19). The growth in non-interest expense was due mainly to higher pay per employee, which advanced at its fastest pace since 1996. The number

19. Non-interest expense as a proportion of revenue, 1985-2003

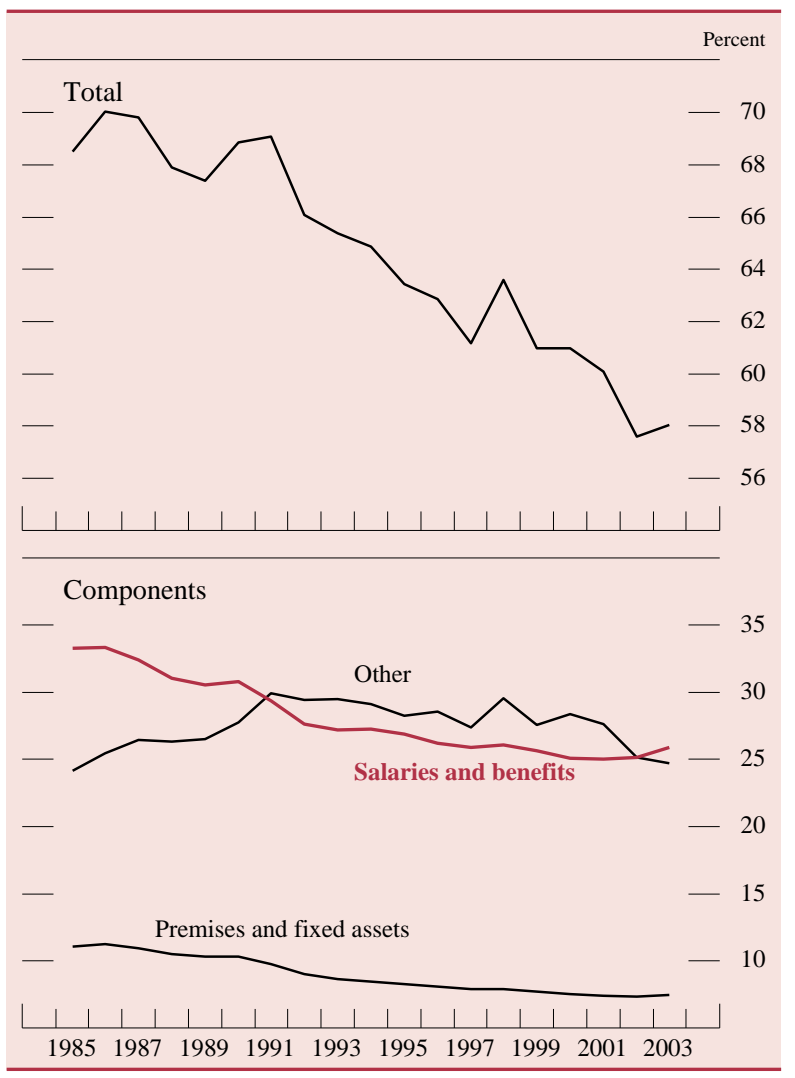

of bank employees rose at about the average rate of the past five years. The ratio of expenses for banks' premises to total revenue continued to be little changed. Other components of non-interest expense grew, but at a slower pace than total revenue.

\section{Loan Performance and Loss Provisioning}

With interest rates low and the economic expansion gaining traction during the year, credit quality improved considerably in 2003. Delinquency rates for nearly all types of loans and leases fell, and by year-end the delinquency rate for all loans and leases was near the low levels of the late 1990s. C\&I loans showed the largest improvement, with much of the deterioration posted in the previous few years being reversed. Overall, charge-off rates also moved down significantly but remained above the average level of the middle and late 1990s.

\section{C\&I Loans}

The delinquency rate on C\&I loans fell 1 full percentage point during 2003, to 2.9 percent in the fourth quarter, the lowest level since the first quarter of 2001 (chart 20). The improvement was particularly notable at the largest 100 banks, where delinquency rates had risen the most. Charge-off rates on these loans also moved down sharply throughout the year.

Respondents to the April 2003 BLPS pointed to lower debt-service burdens as the most important reason for the stabilization in C\&I loan quality. Firms' restructuring of balance sheets to take advantage of low interest rates, as well as the rebound in corporate profits, resulted in a notable decline in business debt-service burdens (chart 21). Banks also cited their own aggressive tightening of lending standards and terms during previous years as a reason for a reduced incidence of problem loans. Indeed, banks first reported tightening C\&I loan standards in 1998, before delinquency rates had begun to rise, and they had tightened standards further, on net, until recently.

Sales by banks of their adversely rated loans to nonbanks was also a likely factor holding down delinquency rates, but charge-offs may have been boosted as banks booked losses on the loans being sold. ${ }^{8}$ Of the largest banks that responded to the October 2003 BLPS, more than 90 percent stated that they had sold at least some adversely rated credits in the secondary

8. Adversely rated loans are loans rated as special mention or classified as substandard, doubtful, or loss. When a bank sells a problem asset, it must charge off the difference between the book value and the selling price. 
20. Delinquency and charge-off rates for loans to businesses, by type of loan, 1991-2003

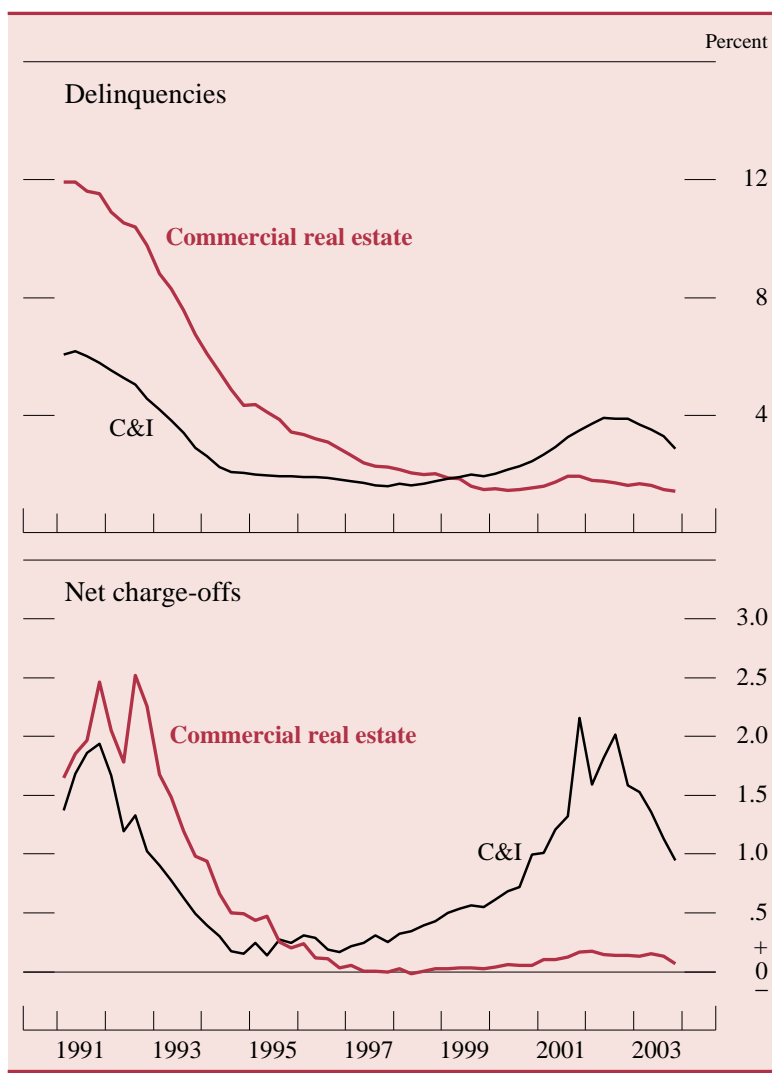

Note. Data are quarterly and seasonally adjusted. Delinquent loans are loans that are not accruing interest and those that are accruing interest but are more than thirty days past due. The delinquency rate is the end-of-period level of delinquent loans divided by the end-of-period level of outstanding loans. The net charge-off rate is the annualized amount of charge-offs over the period, net of recoveries, divided by the average level of outstanding loans over the period.

loan market during the previous two years, and 17 percent reported having sold at least 10 percent of such loans. BLPS respondents reported that many of these loans had been sold to investment banks and other nonbank financial institutions. Consistent with this report, the Shared National Credit Survey shows a substantial increase in the share of adversely rated loan commitments held by nonbank lenders in recent years.

\section{Commercial Real Estate Loans}

Both delinquency and charge-off rates on commercial real estate loans moved down during 2003, although rents on office buildings declined further and vacancy rates remained elevated. Banks reported on the April 2003 BLPS that the high credit quality of commercial real estate loans reflected the reduction in borrowers' debt-service burdens through refinancing and the
21. Debt burdens and financial obligations for businesses and households, 1985-2003

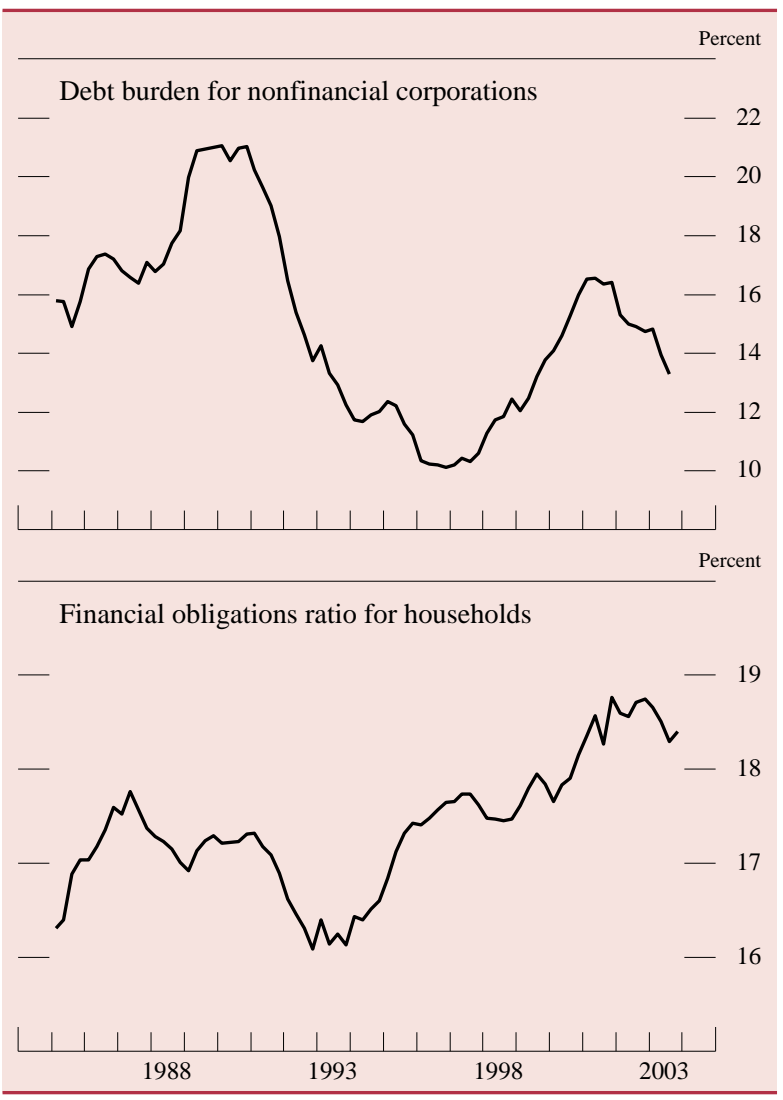

Note. Data are quarterly. The debt burden for nonfinancial corporations is calculated as interest payments as a percentage of cash flow. The financial obligations ratio for households is an estimate of the rate of debt payments and recurring obligations of households to disposable personal income; debt payments and recurring obligations consist of required payments on outstanding mortgage and consumer debt, as well as rent, auto leases, and property taxes.

SouRCE. National income and product accounts and the Federal Reserve System.

tightening of lending terms, including a lowering of loan-to-value ratios. (See box "Quality of Commercial Real Estate Loans" for a more detailed discussion.)

\section{Loans to Households}

Household credit quality also improved last year (chart 22). The delinquency rate on residential mortgage loans reached its lowest level of the past decade, and the delinquency rates on banks' credit card loans and on other consumer loans both moved lower. The improvement in the quality of credit card loans is particularly noteworthy since the household bankruptcy rate, which has generally been correlated with the credit card loan delinquency rate, continued to increase until the middle of 2003 (chart 23). (After 


\section{Quality of Commercial Real Estate Loans}

Conditions in the commercial real estate market have deteriorated during the past few years. Vacancy rates for office buildings began to increase in 2001 and remained near historical highs in 2003 (chart A). Rents on office buildings began to fall in 2001 and tumbled a total of 20 percent through 2003, a larger decline than the one during the downturn in the early 1990s (chart B). Rents on retail properties also declined, though by considerably less.

Despite the deterioration in market conditions, the delinquency rate on commercial mortgages held by banks dropped last year to about 1.5 percent. This rate is well below the nearly 12 percent levels of the early 1990s and is also below the levels of the mid-1990s, when vacancy rates were low and rents were increasing.

A. Vacancy rates on office real estate, 1987:Q4-2003:Q4

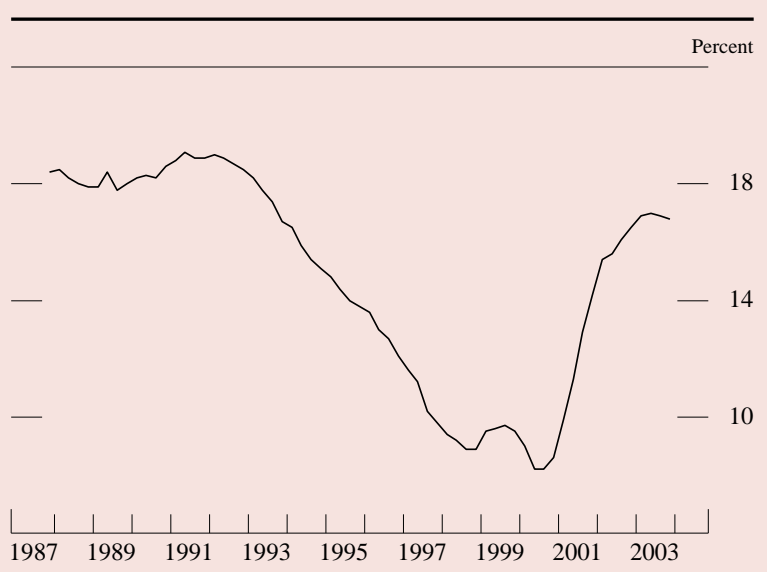

NotE. Data are quarterly.

SOURCE. Torto Wheaton Research.
The delinquency rate has remained low for two possible reasons. First, many borrowers have been able to refinance or roll over their previous mortgages at lower interest rates. Yields on commercial mortgages, in general, have trended down since early 2000 (chart C), so refinancing would have helped borrowers meet their payment obligations. Although still low, the delinquency rate on commercial real estate loans used to back commercial-mortgage-backed securities has risen since 2001. On the January 2004 BLPS, banks reported that the greater difficulty in refinancing such loans, which tend to feature larger prepayment penalties and other prepayment restrictions, was an important reason for the increase in the delinquency rate on securitized loans relative to that on the loans held on banks' books.

B. Change in rent for office and retail space, 1988-2003

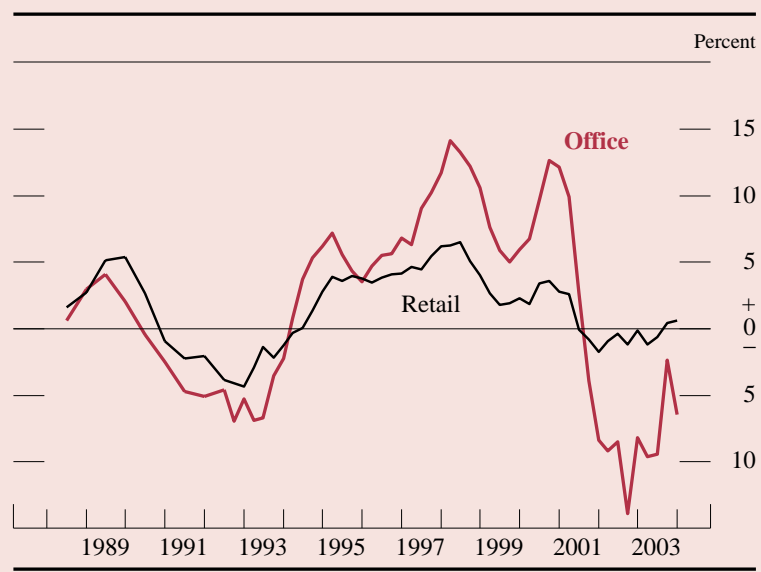

NoTE. The data are four-quarter rates of change. Data before 1991:Q2 are plotted at their available biannual frequency.

SouRCE. National Real Estate Index: Market Monitor. six quarters of decline, the delinquency rate on credit card loans held by banks rose in the fourth quarter of last year, apparently the result of a large bank's acquisition from a nonbank finance company of a sizable portfolio of credit card receivables with a delinquency rate higher than that of the banking system as a whole.) Household balance sheets improved last year as homeowners refinanced their mortgages at lower interest rates, with many extracting equity from their homes through cash-out refinancing or home equity loans and using part of those funds to pay down other, more-expensive debt.

\section{Loss Provisioning}

With the improvement in overall credit quality, banks cut back their loan-loss provisioning in 2003, both in dollar terms and in relation to total revenue (chart 24). The decline was most pronounced at the largest banks, where the ratio had been highest and where credit quality was most improved last year. As loans continued to expand, the ratio of provisioning to loans also declined.

With provisioning just outpacing charge-offs, loan-loss reserves grew 2 percent in 2003-the slowest pace since 1997. The significant improvement in credit quality, however, caused the ratio of loan-loss reserves to delinquent loans to rise 6 percentage points, to 75 percent (chart 25). The ratio of reserves to charge-offs also rose last year, but it remained near the low end of its range over the past decade. With bank balance sheets expanding moderately, reserves as a proportion of total loans slipped to 1.8 percent from 1.9 percent the previous year. 


\section{Quality of Commercial Real Estate Loans-Continued}

The second possible reason for the generally low delinquency rate on commercial real estate loans held by banks is tighter loan standards and terms. After the severe problems in the commercial real estate market during the early 1990s, market participants reportedly reformed industry practices and tightened standards for commercial real estate projects. Also, banks started tightening their lending standards on these loans in 1998, well before the decline in rents and the increase in vacancy rates began. As a result, banks may have avoided riskier projects. According to the January 2002 BLPS and the April 2003 BLPS, banks also tightened their lending terms for commercial real estate

\section{Commercial mortgage yields, 1994-January 2004}

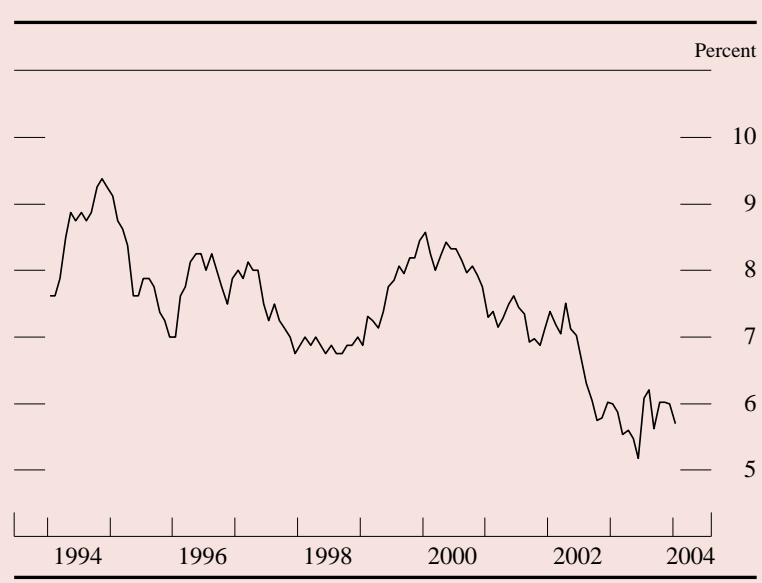

Note. Data are monthly.

SouRCE. Barron's/John B. Levy \& Company. loans. One way that banks did so was by limiting borrowers' leverage. Borrowers with more equity in their properties have a stronger incentive to keep loans current and have a larger cushion if conditions deteriorate. These effects may have been especially important in the recent period because the price of office space has been fairly stable, on net, and the price of retail space has trended higher, possibly because of strong retail sales (chart D). By contrast, in the early 1990s the price of office space dropped markedly and the price of retail space declined, factors that likely increased pressure on borrowers.

D. Prices for commercial property, 1991:Q2-2003:Q4

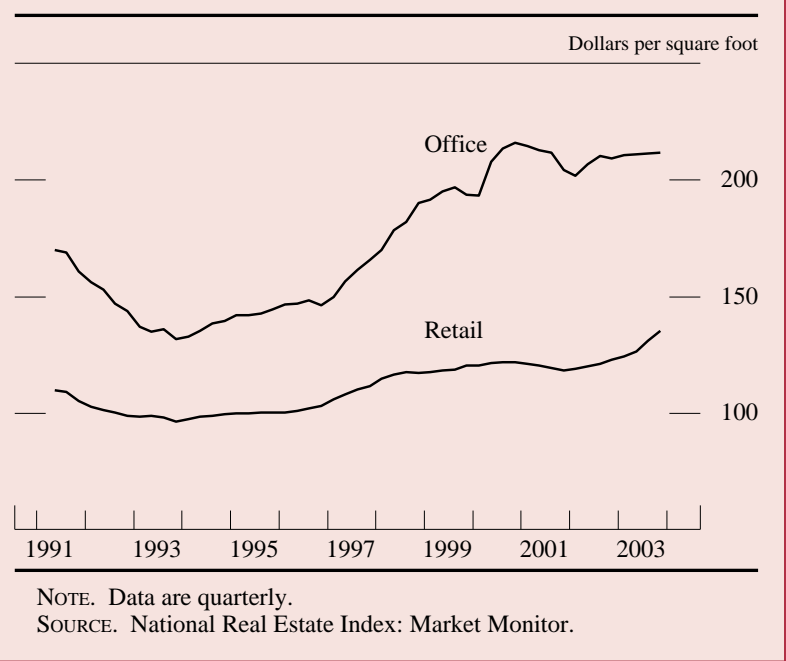

With the rise in the share of bank assets booked in foreign offices, the share of bank income derived from foreign operations moved up slightly in 2003, to 7 percent, although it remained below the levels posted in the mid-1990s. The growth in income occurred during the first half of the year. Earnings from foreign operations dropped off in the latter part of the year, partly because of an increase in loss provisioning for foreign loans.

\section{RECENT DEVELOPMENTS}

Information drawn from the Federal Reserve's weekly H.8 statistical release indicates that banks' asset growth picked up in the first quarter of 2004 . Holdings of securities, especially mortgage-backed securities, increased sharply. Although C\&I loans continued to decine, overall loan growth was strong because of robost real estate and consumer lending. 
22. Delinquency and charge-off rates for loans to households, by type of loan, 1991-2003

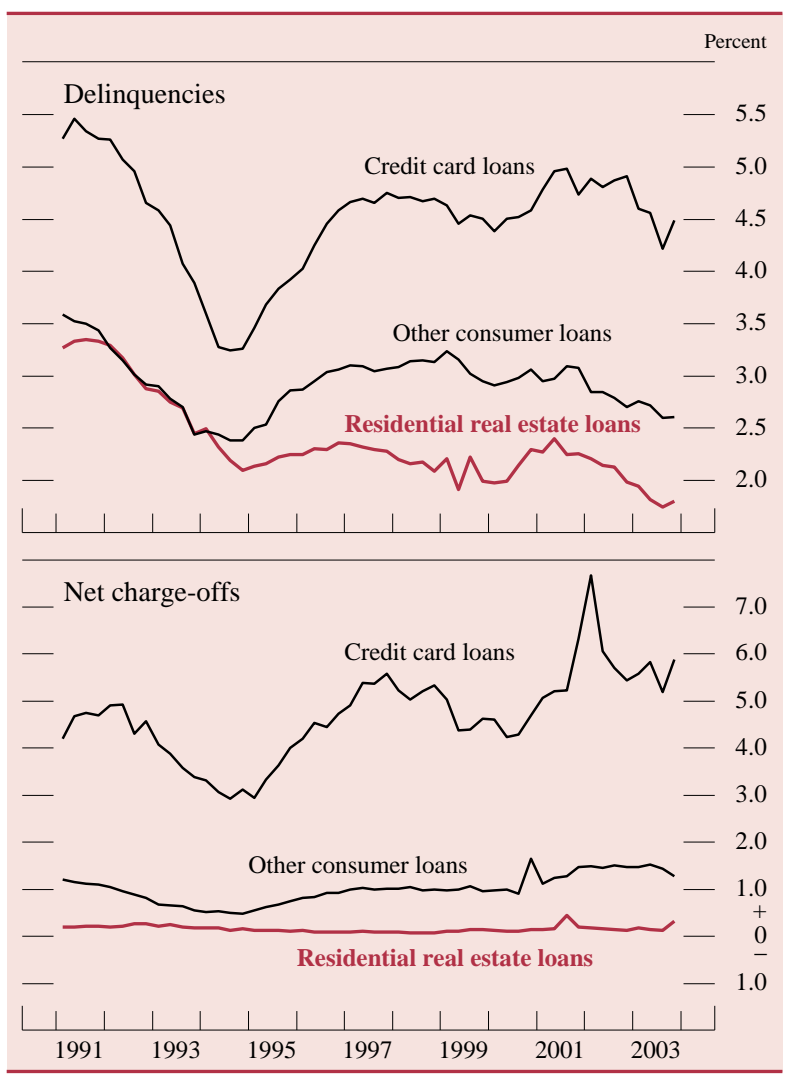

Note. See note to chart 20.

First-quarter earnings statements of several large bank holding companies suggest that bank profitability remained strong in early 2004 . These institutions indicated that the trends of the previous year continued. Improvements in credit quality allowed

23. Credit card delinquency rate and household bankruptcy filings, 1995-2003

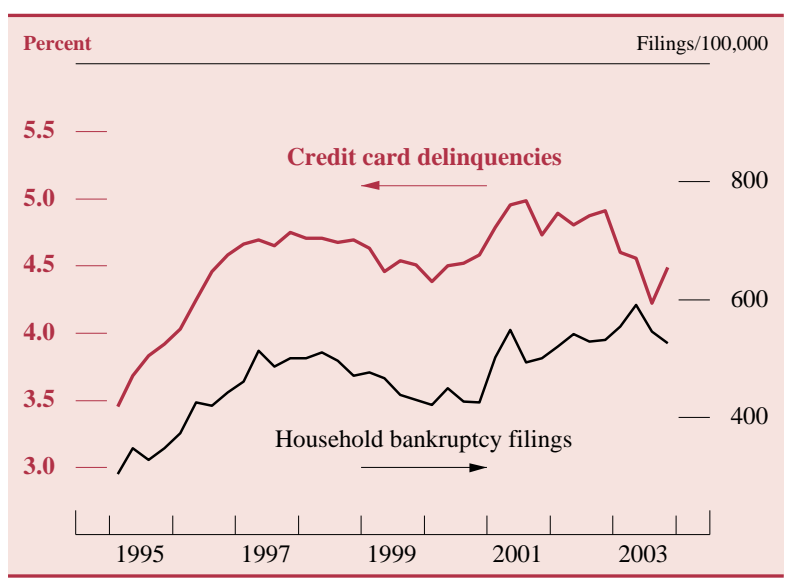

Note. Data are quarterly.

SourCE. Call Report and Visa Bankruptcy Notification Service.
24. Provisioning for loan and lease losses as a percentage of total revenue, 1991-2003

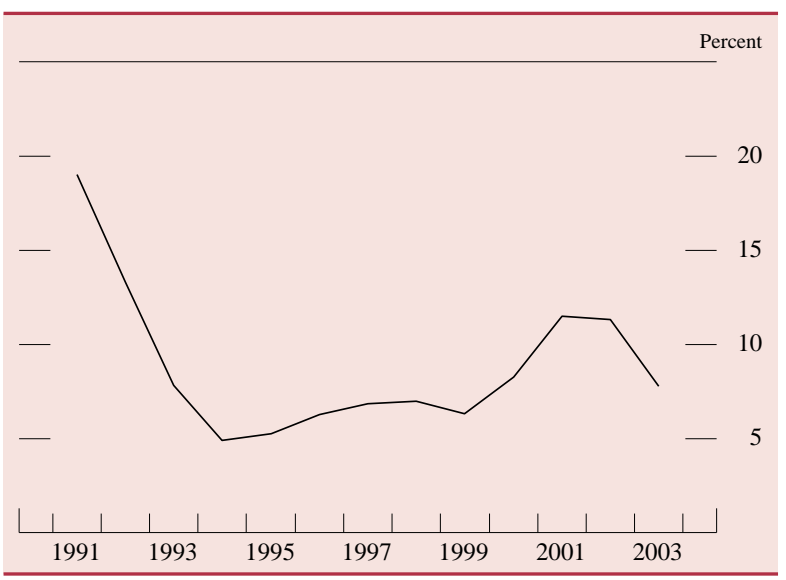

for further reductions in loss provisioning. Noninterest income benefited from increased fees from trust and investment services. With net interest margins still under pressure, growth in net interest income remained sluggish. Stock prices of bank holding companies generally moved with the Wilshire 5000 during the first quarter before falling

\section{Reserves for loan and lease losses, 1985-2003}

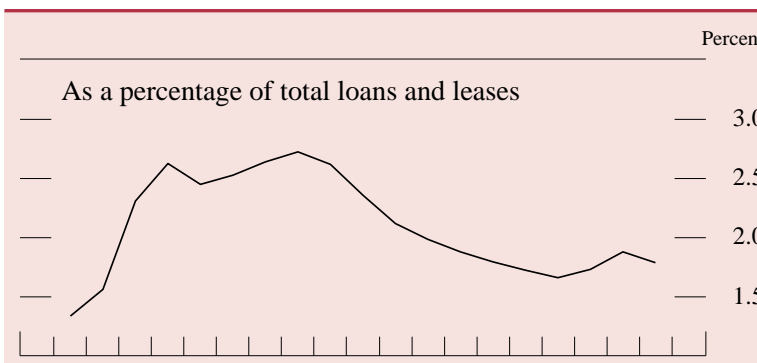

As a percentage of delinquent loans
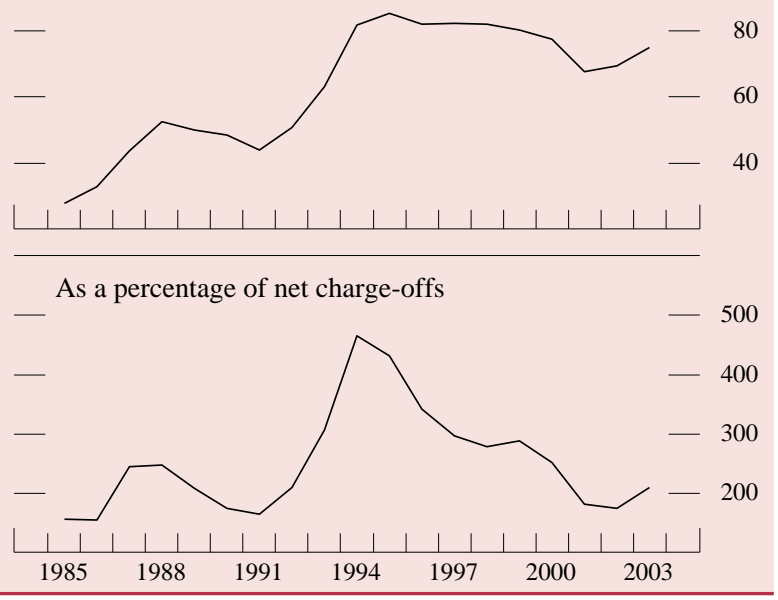

Note. For definitions of delinquencies and net charge-offs, see note to chart 20. 
2. Exposure of banks to selected economies at year-end relative to tier 1 capital, by bank size, 1998-2003 Percent

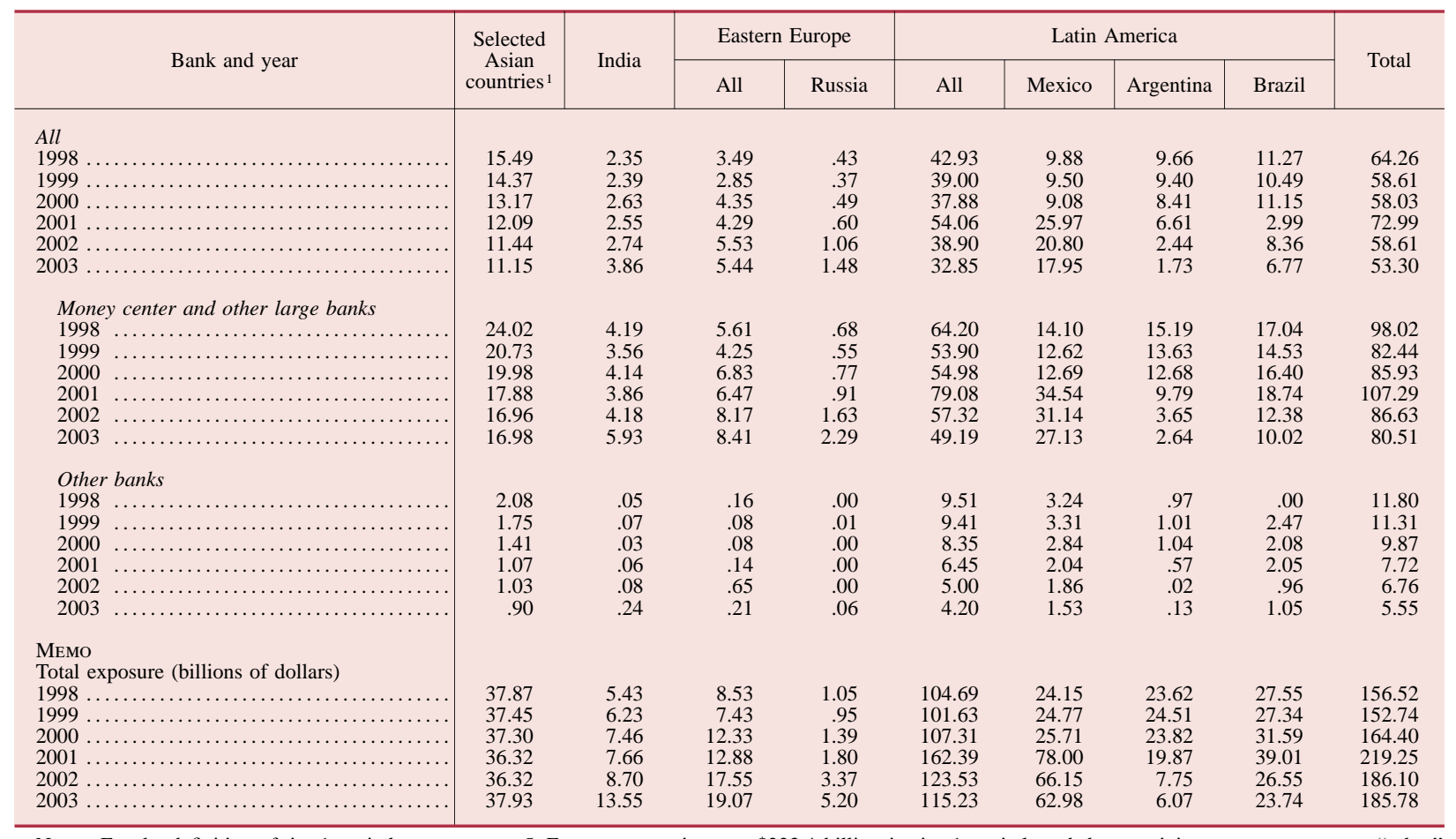

Note. For the definition of tier 1 capital, see text note 5. Exposures consist of lending and derivatives exposures for cross-border and local-office operations. Respondents may file information on one bank or on the bank holding company as a whole.

At year-end 2003, "all reporting" banks consisted of seventy-two institutions with a total of $\$ 350.8$ billion in tier 1 capital; of these institutions, ten were "large" banks (five money center banks and five other large banks) with

in mid-April as market participants reportedly became concerned about the possible effects of rising interest rates on bank profitability. With the
$\$ 223.4$ billion in tier 1 capital, and the remaining seventy-two were "other" banks with $\$ 127.5$ billion in tier 1 capital. The average "other" bank at yearend 2003 had $\$ 26$ billion in assets.

1. Indonesia, Korea, Malaysia, Philippines, and Thailand.

Source. Federal Financial Institutions Examination Council Statistical Release E.16, "Country Exposure Survey," available at www.ffiec.gov/E16.htm.

announcements of several large mergers in early 2004, industry consolidation, which had been relatively subdued in 2003 , appeared to be picking up. 
A.1. Report of income, all U.S. banks, 1994-2003 Millions of dollars

\begin{tabular}{|c|c|c|c|c|c|c|c|c|c|c|}
\hline Item & 1994 & 1995 & 1996 & 1997 & 1998 & 1999 & 2000 & 2001 & 2002 & 2003 \\
\hline Gross interest income & 256,854 & 302,202 & 313,240 & 338,216 & 359,138 & 366,123 & 423,823 & 404,564 & 350,217 & 329,765 \\
\hline Taxable equivalent & 259,610 & 304,838 & 315,700 & 340,648 & 361,601 & 368,750 & 426,459 & 407,246 & 352,965 & 332,548 \\
\hline Loans $\ldots \ldots \ldots \ldots$ & 189,567 & 227,049 & 239,395 & 255,492 & 270,904 & 278,524 & 326,789 & 311,858 & 270,070 & 258,160 \\
\hline Securities $\ldots \ldots \ldots \ldots \ldots \ldots$ & 48,286 & 51,029 & 50,631 & 52,659 & 56,596 & 62,115 & 67,659 & 63,064 & 59,316 & 53,310 \\
\hline $\begin{array}{l}\text { Gross federal funds sold and reverse } \\
\text { repurchase agreements } \ldots \ldots \ldots \ldots\end{array}$ & 6,415 & 9,744 & 9,272 & 13,658 & 14,999 & 12,327 & 13,546 & 12,647 & 6,222 & 5,122 \\
\hline Other $\ldots \ldots \ldots \ldots \ldots \ldots \ldots \ldots \ldots \ldots \ldots$ & 12,587 & 14,382 & 13,944 & 16,406 & 16,637 & 13,155 & 15,829 & 16,994 & 14,610 & 13,176 \\
\hline Gross interest expense .. & 110,785 & 147,909 & 150,097 & 164,511 & 178,021 & 174,939 & 222,146 & 188,793 & 118,915 & 94,419 \\
\hline Deposits . ...................... & 79,086 & 105,326 & 107,512 & 117,350 & 125,217 & 119,665 & 151,138 & 132,368 & 81,894 & 62,705 \\
\hline $\begin{array}{l}\text { Gross federal funds purchased and } \\
\text { repurchase agreements } \ldots \ldots \ldots\end{array}$ & 12,474 & 18,424 & 16,780 & 20,439 & 22,182 & 21,130 & 26,859 & 19,583 & 9,919 & 7,590 \\
\hline Other $\ldots \ldots \ldots \ldots \ldots \ldots \ldots$ & 19,224 & 24,158 & 25,806 & 26,721 & 30,620 & 34,143 & 44,151 & 36,841 & 27,101 & 24,125 \\
\hline Net interest income .... & 146,069 & 154,293 & 163,143 & 173,705 & 181,117 & 191,184 & 201,677 & 215,771 & 231,302 & 235,346 \\
\hline Taxable equivalent & 148,825 & 156,929 & 165,603 & 176,137 & 183,580 & 193,811 & 204,313 & 218,453 & 234,050 & 238,129 \\
\hline Loss provisioning & 10,930 & 12,570 & 16,211 & 19,176 & 21,249 & 21,182 & 29,381 & 43,236 & 45,297 & 32,682 \\
\hline Non-interest income $\ldots \ldots \ldots$ & 77,231 & 83,846 & 95,305 & 105,628 & 123,516 & 144,400 & 153,154 & 160,297 & 168,540 & 183,520 \\
\hline Service charges on deposits & 15,279 & 16,056 & 17,050 & 18,558 & 19,769 & 21,497 & 23,719 & 26,873 & 29,631 & 31,692 \\
\hline Fiduciary activities ......... & 12,148 & 12,889 & 14,296 & 16,584 & 19,268 & 20,502 & 22,220 & 21,989 & 21,637 & 22,306 \\
\hline Trading revenue $\ldots \ldots \ldots$ & 6,249 & 6,337 & 7,525 & 8,018 & 7,693 & 10,429 & 12,235 & 12,547 & 10,734 & 11,444 \\
\hline Other $\ldots \ldots \ldots \ldots$ & 43,556 & 48,563 & 56,433 & 62,468 & 76,786 & 91,972 & 94,980 & 98,886 & 106,536 & 118,077 \\
\hline Non-interest expense $\ldots \ldots \ldots \ldots \ldots \ldots$ & 144,837 & 151,077 & 162,450 & 170,880 & 193,701 & 204,625 & 216,423 & 226,025 & 230,331 & 243,184 \\
\hline Salaries, wages, and employee benefits & 60,884 & 63,996 & 67,796 & 72,310 & 79,503 & 86,150 & 89,034 & 94,234 & 100,483 & 108,437 \\
\hline Occupancy $\ldots \ldots \ldots \ldots \ldots \ldots \ldots \ldots \ldots$ & 18,972 & 19,758 & 20,888 & 22,074 & 24,160 & 25,865 & 26,764 & 27,940 & 29,317 & 31,313 \\
\hline Other ...... & 64,982 & 67,323 & 73,765 & 76,495 & 90,038 & 92,610 & 100,626 & 103,852 & 100,529 & 103,433 \\
\hline Net non-interest expense & 67,606 & 67,231 & 67,145 & 65,252 & 70,185 & 60,225 & 63,269 & 65,728 & 61,791 & 59,664 \\
\hline $\begin{array}{r}\text { Gains on investment account } \\
\text { securities } \ldots \ldots \ldots \ldots \ldots\end{array}$ & -573 & 481 & 1,123 & 1,825 & 3,090 & 250 & $-2,280$ & 4,624 & 6,415 & 5,639 \\
\hline Income before taxes & 66,959 & 74,974 & 80,907 & 91,101 & 92,774 & 110,028 & 106,746 & 111,427 & 130,502 & 148,537 \\
\hline Taxes $\ldots \ldots \ldots \ldots \ldots \ldots \ldots \ldots \ldots$ & 22,427 & 26,221 & 28,448 & 31,973 & 31,872 & 39,202 & 37,250 & 37,112 & 42,973 & 48,446 \\
\hline Extraordinary items, net of income taxes & -17 & 28 & 88 & 56 & 506 & 169 & -31 & -324 & -78 & 428 \\
\hline Net income & 44,515 & 48,780 & 52,550 & 59,184 & 61,408 & 70,996 & 69,464 & 73,992 & 87,451 & 100,520 \\
\hline Cash dividends declared & 28,167 & 31,106 & 39,419 & 42,752 & 41,205 & 51,955 & 52,547 & 54,821 & 67,218 & 77,750 \\
\hline Retained income ....... & 16,347 & 17,676 & 13,131 & 16,433 & 20,202 & 19,042 & 16,917 & 19,171 & 20,233 & 22,770 \\
\hline
\end{tabular}


A.2. Portfolio composition, interest rates, and income and expense, all U.S. banks, 1994-2003 A. All banks

\begin{tabular}{|c|c|c|c|c|c|c|c|c|c|c|}
\hline Item & 1994 & 1995 & 1996 & 1997 & 1998 & 1999 & 2000 & 2001 & 2002 & 2003 \\
\hline & \multicolumn{10}{|c|}{ Balance sheet items as a percentage of average net consolidated assets } \\
\hline Interest-earning assets & 87.10 & 86.97 & 87.38 & 87.15 & 86.76 & 87.03 & 87.13 & 86.48 & 86.42 & 86.06 \\
\hline Loans and leases, net $\ldots \ldots$ & 56.05 & 58.37 & 59.89 & 58.69 & 58.31 & 59.34 & 60.48 & 58.95 & 57.83 & 56.87 \\
\hline Commercial and industrial & 14.52 & 15.20 & 15.60 & 15.78 & 16.37 & 17.07 & 17.16 & 16.08 & 14.08 & 12.20 \\
\hline U.S. addressees ......... & 12.36 & 12.87 & 13.07 & 13.18 & 13.62 & 14.43 & 14.67 & 13.69 & 12.04 & 10.49 \\
\hline Foreign addressees $\ldots$. & 2.16 & 2.33 & 2.53 & 2.60 & 2.75 & 2.64 & 2.49 & 2.39 & 2.04 & 1.70 \\
\hline Consumer...$\ldots \ldots \ldots$ & 11.40 & 12.08 & 12.21 & 11.44 & 10.36 & 9.71 & 9.38 & 9.23 & 9.35 & 9.06 \\
\hline Credit card $\ldots \ldots \ldots \ldots$ & 4.19 & 4.68 & 4.87 & 4.55 & 3.96 & 3.51 & 3.52 & 3.63 & 3.78 & 3.55 \\
\hline Installment and other & 7.22 & 7.39 & 7.34 & 6.89 & 6.39 & 6.20 & 5.87 & 5.60 & 5.57 & 5.51 \\
\hline Real estate.....$\ldots \ldots$ & 24.44 & 25.02 & 25.06 & 25.02 & 24.86 & 25.44 & 27.04 & 27.10 & 28.39 & 29.91 \\
\hline In domestic offices $\ldots \ldots \ldots \ldots \ldots \ldots$ & 23.81 & 24.37 & 24.43 & 24.41 & 24.29 & 24.87 & 26.49 & 26.60 & 27.91 & 29.46 \\
\hline Construction and land development & 1.65 & 1.59 & 1.63 & 1.73 & 1.86 & 2.18 & 2.51 & 2.85 & 2.98 & 2.99 \\
\hline Farmland..$\ldots \ldots \ldots \ldots \ldots \ldots$ & .57 & .56 & .56 & .55 & .55 & .56 & .56 & .55 & .56 & .54 \\
\hline One- to four-family residential & 13.74 & 14.42 & 14.43 & 14.42 & 14.26 & 14.10 & 14.96 & 14.67 & 15.40 & 16.96 \\
\hline Home equity $\ldots \ldots \ldots \ldots \ldots$ & 1.90 & 1.88 & 1.85 & 1.94 & 1.89 & 1.76 & 1.96 & 2.18 & 2.80 & 3.40 \\
\hline Other...... & 11.84 & 12.54 & 12.57 & 12.48 & 12.37 & 12.34 & 13.00 & 12.49 & 12.60 & 13.56 \\
\hline Multifamily residential & .79 & .81 & .85 & .83 & .82 & .88 & .99 & .97 & 1.02 & 1.05 \\
\hline Nonfarm nonresidential & 7.07 & 6.97 & 6.96 & 6.88 & 6.81 & 7.15 & 7.48 & 7.56 & 7.95 & 7.91 \\
\hline In foreign offices $\ldots \ldots \ldots \ldots \ldots \ldots \ldots$ & .63 & .65 & .63 & .61 & .57 & .57 & .54 & .50 & .48 & .46 \\
\hline \multicolumn{11}{|l|}{ To depository institutions and acceptances } \\
\hline of other banks $\ldots \ldots \ldots \ldots \ldots \ldots \ldots$ & 1.47 & 1.92 & 2.33 & 1.93 & 1.91 & 1.96 & 1.87 & 1.83 & 1.87 & 1.97 \\
\hline Foreign governments . & .41 & .30 & .26 & .18 & .15 & .16 & .12 & .10 & .09 & .08 \\
\hline Agricultural production & 1.00 & .96 & .92 & .90 & .89 & .83 & .78 & .75 & .70 & .63 \\
\hline Other loans ............... & 3.29 & 3.11 & 3.32 & 2.80 & 2.78 & 2.75 & 2.58 & 2.34 & 2.06 & 1.98 \\
\hline Lease-financing receivables $\ldots .$. & 1.03 & 1.19 & 1.51 & 1.87 & 2.13 & 2.52 & 2.63 & 2.58 & 2.44 & 2.12 \\
\hline LEss: Unearned income on loans & -.16 & -.14 & -.12 & -.09 & -.07 & -.06 & -.05 & -.04 & -.05 & -.04 \\
\hline LESS: Loss reserves ${ }^{1} \ldots \ldots \ldots \ldots$ & -1.35 & -1.26 & -1.21 & -1.13 & -1.07 & -1.04 & -1.02 & -1.04 & -1.11 & -1.04 \\
\hline Securities $\ldots \ldots \ldots \ldots \ldots \ldots \ldots$ & 24.32 & 21.94 & 21.01 & 20.41 & 20.38 & 20.40 & 20.01 & 19.53 & 21.27 & 21.89 \\
\hline Investment account & 21.61 & 19.39 & 18.20 & 17.25 & 17.49 & 18.33 & 17.59 & 16.82 & 18.30 & 18.96 \\
\hline Debt $\ldots \ldots \ldots \ldots$ & 21.22 & 18.98 & 17.75 & 16.75 & 16.94 & 17.73 & 16.93 & 16.48 & 17.99 & 18.72 \\
\hline U.S. Treasury $\ldots \ldots \ldots \ldots$ & 6.72 & 5.25 & 4.20 & 3.38 & 2.71 & 2.14 & 1.66 & .85 & .78 & .90 \\
\hline \multicolumn{11}{|l|}{ U.S. government agency and } \\
\hline corporation obligations $\ldots \ldots \ldots$ & 10.26 & 9.81 & 9.75 & 9.74 & 10.28 & 10.85 & 10.31 & 10.08 & 11.46 & 12.26 \\
\hline Government-backed mortgage pools & 4.70 & 4.47 & 4.80 & 4.94 & 5.17 & 5.24 & 4.75 & 5.13 & 6.09 & 6.75 \\
\hline Collateralized mortgage obligations . & 3.19 & 2.67 & 2.11 & 1.94 & 2.12 & 2.15 & 1.92 & 1.95 & 2.35 & 2.34 \\
\hline Other $\ldots \ldots \ldots \ldots \ldots \ldots \ldots \ldots$ & 2.36 & 2.68 & 2.83 & 2.86 & 2.99 & 3.46 & 3.63 & 2.99 & 3.02 & 3.17 \\
\hline 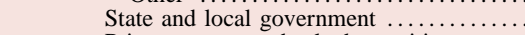 & 2.01 & 1.80 & 1.68 & 1.59 & 1.57 & 1.62 & 1.52 & 1.49 & 1.49 & 1.48 \\
\hline Private mortgage-backed securities & .64 & .62 & .61 & .50 & .67 & .88 & .95 & 1.09 & 1.25 & 1.30 \\
\hline Other $\ldots \ldots \ldots \ldots \ldots \ldots \ldots \ldots \ldots$ & 1.56 & 1.49 & 1.51 & 1.54 & 1.71 & 2.24 & 2.48 & 2.98 & 3.01 & 2.78 \\
\hline Equity $^{2} \ldots \ldots$ & .39 & .41 & .45 & .50 & .55 & .61 & .66 & .34 & .31 & .25 \\
\hline Trading account $\ldots \ldots \ldots \ldots \ldots \ldots \ldots \ldots$ & 2.71 & 2.55 & 2.81 & 3.16 & 2.90 & 2.06 & 2.43 & 2.72 & 2.97 & 2.93 \\
\hline Gross federal funds sold and reverse RPs & 3.83 & 3.93 & 3.82 & 5.18 & 5.37 & 4.61 & 4.12 & 5.11 & 4.81 & 4.85 \\
\hline Interest-bearing balances at depositories .... & 2.90 & 2.73 & 2.66 & 2.86 & 2.69 & 2.68 & 2.52 & 2.89 & 2.51 & 2.45 \\
\hline Non-interest-earning assets $\ldots \ldots \ldots \ldots \ldots \ldots$ & 12.90 & 13.03 & 12.62 & 12.85 & 13.24 & 12.97 & 12.87 & 13.52 & 13.58 & 13.94 \\
\hline Revaluation gains held in trading accounts 3 & 2.95 & 2.90 & 2.25 & 2.59 & 2.95 & 2.57 & 2.28 & 2.37 & 2.42 & 2.70 \\
\hline Other $\ldots \ldots \ldots \ldots \ldots \ldots \ldots \ldots \ldots \ldots \ldots \ldots \ldots \ldots \ldots \ldots \ldots$ & 9.95 & 10.12 & 10.38 & 10.26 & 10.29 & 10.40 & 10.58 & 11.15 & 11.16 & 11.23 \\
\hline Liabilities $\ldots \ldots \ldots \ldots \ldots \ldots$. & 92.12 & 91.99 & 91.73 & 91.57 & 91.51 & 91.52 & 91.58 & 91.25 & 90.85 & 90.96 \\
\hline Interest-bearing liabilities & 71.85 & 71.86 & 71.62 & 71.36 & 71.33 & 72.52 & 73.30 & 72.47 & 71.20 & 70.50 \\
\hline 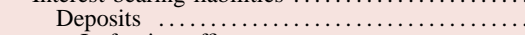 & 57.36 & 56.31 & 55.87 & 55.01 & 54.65 & 54.79 & 54.66 & 54.59 & 53.87 & 53.31 \\
\hline In foreign offices $\ldots \ldots \ldots \ldots \ldots \ldots$ & 9.39 & 10.28 & 10.01 & 10.02 & 10.15 & 10.46 & 10.92 & 10.17 & 8.92 & 8.90 \\
\hline In domestic offices $\ldots \ldots \ldots$ & 47.97 & 46.03 & 45.86 & 44.99 & 44.50 & 44.33 & 43.74 & 44.42 & 44.95 & 44.40 \\
\hline Other checkable deposits .... & 7.80 & 6.63 & 4.75 & 3.62 & 3.11 & 2.81 & 2.46 & 2.36 & 2.39 & 2.47 \\
\hline Savings (including MMDAs) $\ldots . .$. & 19.60 & 17.48 & 18.71 & 19.12 & 19.91 & 21.00 & 20.64 & 22.28 & 24.92 & 26.10 \\
\hline Small-denomination time deposits $\ldots$ & 15.33 & 16.15 & 15.97 & 15.17 & 14.15 & 13.10 & 12.49 & 11.59 & 10.13 & 8.65 \\
\hline Large-denomination time deposits $\ldots$ & 5.23 & 5.77 & 6.42 & 7.08 & 7.33 & 7.42 & 8.16 & 8.18 & 7.51 & 7.18 \\
\hline Gross federal funds purchased and RPs ... & 7.60 & 7.71 & 7.18 & 8.13 & 7.99 & 7.97 & 7.83 & 7.95 & 7.77 & 7.75 \\
\hline 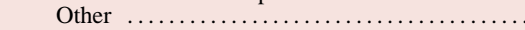 & 6.89 & 7.85 & 8.56 & 8.21 & 8.69 & 9.76 & 10.81 & 9.92 & 9.56 & 9.45 \\
\hline Non-interest-bearing liabilities ........ & 20.27 & 20.13 & 20.11 & 20.21 & 20.18 & 19.00 & 18.28 & 18.78 & 19.65 & 20.46 \\
\hline Demand deposits in domestic offices .............. & 13.49 & 12.68 & 12.82 & 12.16 & 11.00 & 9.78 & 8.61 & 8.00 & 7.67 & 7.22 \\
\hline Revaluation losses held in trading accounts ${ }^{3}$ & 2.69 & 2.88 & 2.14 & 2.64 & 2.97 & 2.52 & 2.29 & 2.21 & 2.09 & 2.30 \\
\hline 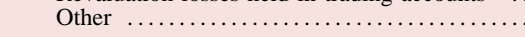 & 4.56 & 4.57 & 5.14 & 5.42 & 6.21 & 6.70 & 7.37 & 8.57 & 9.90 & 10.94 \\
\hline Capital account & 7.88 & 8.01 & 8.27 & 8.43 & 8.49 & 8.48 & 8.42 & 8.75 & 9.15 & 9.04 \\
\hline \multicolumn{11}{|l|}{ Мемо } \\
\hline Commercial real estate loans & 9.94 & 9.83 & 9.92 & 9.99 & 10.12 & 10.87 & 11.58 & 12.09 & 12.57 & 12.48 \\
\hline Other real estate owned .......... & .36 & .19 & .14 & .11 & .08 & .06 & .05 & .05 & .06 & .06 \\
\hline Managed liabilities ................ & 29.60 & 32.08 & 32.73 & 34.09 & 34.94 & 36.58 & 38.83 & 37.42 & 35.05 & 34.66 \\
\hline \multicolumn{3}{|l|}{ Average net consolidated assets } & 4,376 & 4,733 & 5,145 & 5,439 & 5,906 & 6,334 & 6,635 & 7,249 \\
\hline
\end{tabular}


A.2.-Continued

A. All banks

\begin{tabular}{|c|c|c|c|c|c|c|c|c|c|c|}
\hline Item & 1994 & 1995 & 1996 & 1997 & 1998 & 1999 & 2000 & 2001 & 2002 & 2003 \\
\hline & \multicolumn{10}{|c|}{ Effective interest rate (percent) ${ }^{4}$} \\
\hline \multicolumn{11}{|l|}{ Rates earned } \\
\hline Interest-earning assets .. & 7.61 & 8.33 & 8.14 & 8.15 & 7.99 & 7.70 & 8.22 & 7.36 & 6.08 & 5.27 \\
\hline Taxable equivalent ... & 7.69 & 8.40 & 8.22 & 8.22 & 8.06 & 7.76 & 8.26 & 7.44 & 6.17 & 5.35 \\
\hline Loans and leases, gross ... & 8.62 & 9.24 & 9.00 & 9.01 & 8.85 & 8.47 & 9.00 & 8.16 & 6.91 & 6.16 \\
\hline Net of loss provisions & 8.32 & 8.92 & 8.56 & 8.50 & 8.30 & 7.97 & 8.33 & 7.15 & 5.86 & 5.48 \\
\hline Securities.$\ldots \ldots \ldots \ldots \ldots$ & 5.97 & 6.51 & 6.46 & 6.54 & 6.45 & 6.27 & 6.47 & 6.08 & 4.98 & 3.99 \\
\hline Taxable equivalent & 6.20 & 6.73 & 6.66 & 6.73 & 6.63 & 6.46 & 6.65 & 6.26 & 5.14 & 4.13 \\
\hline Investment account $\ldots \ldots \ldots \ldots \ldots \ldots$ & 5.80 & 6.35 & 6.39 & 6.50 & 6.38 & 6.25 & 6.45 & 6.05 & 5.04 & 4.00 \\
\hline \multicolumn{9}{|l|}{ U.S. Treasury securities and U.S. } & 4.42 & 3.29 \\
\hline Mortgage-backed securities $\ldots \ldots \ldots$ & $\begin{array}{l}\text { I1.a. } \\
\text { n.a. }\end{array}$ & $\begin{array}{l}\text { In.a. } \\
\text { n.a. }\end{array}$ & $\begin{array}{l}\text { n.a. } \\
\text { n.a. }\end{array}$ & $\begin{array}{l}\text { n.a. } \\
\text { n.a. }\end{array}$ & $\begin{array}{l}\text { 11.a. } \\
\text { n.a. }\end{array}$ & $\begin{array}{l}\text { n.a. } \\
\text { n.a. }\end{array}$ & $\begin{array}{l}\text { n.a. } \\
\text { n.a. }\end{array}$ & $\begin{array}{l}5.76 \\
6.45\end{array}$ & $\begin{array}{l}4.42 \\
5.44\end{array}$ & $\begin{array}{l}3.29 \\
4.24\end{array}$ \\
\hline Other $\ldots \ldots \ldots \ldots \ldots \ldots \ldots$ & n.a. & n.a. & $\begin{array}{l}\text { II.a. } \\
\text { n.a. }\end{array}$ & n.a. & n.a. & $\begin{array}{l}\text { II.a. } \\
\text { n.a. }\end{array}$ & n.a. & 5.60 & 4.74 & 4.08 \\
\hline Trading account $\ldots \ldots \ldots \ldots \ldots \ldots \ldots \ldots$ & 7.41 & 7.73 & 6.86 & 6.75 & 6.85 & 6.47 & 6.63 & 6.34 & 4.59 & 3.94 \\
\hline Gross federal funds sold and reverse RPs & 4.26 & 5.63 & 5.21 & 5.45 & 5.29 & 4.78 & 5.56 & 3.86 & 1.93 & 1.43 \\
\hline Interest-bearing balances at depositories .. & 5.71 & 6.84 & 6.20 & 6.23 & 6.32 & 5.95 & 6.48 & 4.01 & 2.79 & 2.09 \\
\hline \multicolumn{11}{|l|}{ Rates paid } \\
\hline Interest-bearing liabilities. & 4.01 & 4.99 & 4.82 & 4.92 & 4.88 & 4.47 & 5.17 & 4.15 & 2.54 & 1.87 \\
\hline Interest-bearing deposits & 3.53 & 4.47 & 4.34 & 4.39 & 4.31 & 3.87 & 4.45 & 3.61 & 2.12 & 1.48 \\
\hline In foreign offices .... & 5.59 & 6.12 & 5.54 & 5.44 & 5.66 & 4.91 & 5.61 & 3.94 & 2.38 & 1.64 \\
\hline In domestic offices ......... & 3.14 & 4.11 & 4.07 & 4.16 & 4.01 & 3.63 & 4.17 & 3.54 & 2.07 & 1.45 \\
\hline Other checkable deposits & 1.85 & 2.06 & 2.04 & 2.25 & 2.29 & 2.08 & 2.34 & 1.96 & 1.06 & .77 \\
\hline Savings (including MMDAs) . & 2.58 & 3.19 & 3.00 & 2.93 & 2.79 & 2.49 & 2.86 & 2.19 & 1.13 & .74 \\
\hline Large time deposits 5 ........ & 4.09 & 5.47 & 5.39 & 5.45 & 5.22 & 4.92 & 5.78 & 5.04 & 3.38 & 2.58 \\
\hline Other time deposits ${ }^{5} \quad \ldots \ldots \ldots \ldots$ & 4.17 & 5.44 & 5.40 & 5.54 & 5.48 & 5.09 & 5.69 & 5.43 & 3.73 & 2.91 \\
\hline Gross federal funds purchased and RPs .. & 4.18 & 5.65 & 5.12 & 5.17 & 5.19 & 4.73 & 5.77 & 3.83 & 1.88 & 1.30 \\
\hline \multirow[t]{2}{*}{ Other interest-bearing liabilities ........... } & 7.25 & 7.46 & 6.93 & 6.94 & 6.89 & 6.48 & 6.97 & 5.92 & 4.32 & 3.57 \\
\hline & \multicolumn{10}{|c|}{ Income and expense as a percentage of average net consolidated assets } \\
\hline Gross interest income . & 6.65 & 7.29 & 7.16 & 7.15 & 6.98 & 6.73 & 7.18 & 6.39 & 5.28 & 4.55 \\
\hline Taxable equivalent & 6.72 & 7.35 & 7.21 & 7.20 & 7.03 & 6.78 & 7.22 & 6.43 & 5.32 & 4.59 \\
\hline Loans $. . . \ldots \ldots \ldots . . .$. & 4.91 & 5.47 & 5.47 & 5.40 & 5.27 & 5.12 & 5.53 & 4.92 & 4.07 & 3.56 \\
\hline Securities $\ldots \ldots \ldots \ldots \ldots \ldots \ldots \ldots \ldots$ & 1.25 & 1.23 & 1.16 & 1.11 & 1.10 & 1.14 & 1.15 & 1.00 & .89 & .74 \\
\hline Gross federal funds sold and reverse RPs & .17 & .23 & .21 & .29 & .29 & .23 & .23 & .20 & .09 & .07 \\
\hline Other $\ldots \ldots \ldots \ldots \ldots \ldots \ldots \ldots \ldots$ & .33 & .35 & .32 & .35 & .32 & .24 & .27 & .24 & .18 & .15 \\
\hline Gross interest expense & 2.87 & 3.57 & 3.43 & 3.48 & 3.46 & 3.22 & 3.76 & 2.98 & 1.79 & 1.30 \\
\hline Deposits ........... & 2.05 & 2.54 & 2.46 & 2.48 & 2.43 & 2.20 & 2.56 & 2.09 & 1.23 & .86 \\
\hline Gross federal funds purchased and RPs & .32 & .44 & .38 & .43 & .43 & .39 & .45 & .31 & .15 & .10 \\
\hline Other $\ldots \ldots \ldots \ldots \ldots \ldots \ldots \ldots \ldots \ldots \ldots$ & .50 & .58 & $\begin{array}{l}.50 \\
.59\end{array}$ & .56 & .60 & .63 & .75 & .58 & .41 & .33 \\
\hline Net interest income .... & 3.78 & 3.72 & 3.73 & 3.67 & 3.52 & 3.51 & 3.41 & 3.41 & 3.49 & 3.25 \\
\hline Taxable equivalent & 3.85 & 3.78 & 3.78 & 3.72 & 3.57 & 3.56 & 3.46 & 3.45 & 3.53 & 3.28 \\
\hline Loss provisioning 6 & .28 & .30 & .37 & .41 & .41 & .39 & .50 & 68 & .68 & .45 \\
\hline Non-interest income ......... & 2.00 & 2.02 & 2.18 & 2.23 & 2.40 & 2.65 & 2.59 & 2.53 & 2.54 & 2.53 \\
\hline Service charges on deposits & .40 & .39 & .39 & .39 & .38 & .40 & .40 & .42 & .45 & .44 \\
\hline Fiduciary activities $\ldots \ldots \ldots \ldots$. & .31 & .31 & .33 & .35 & .37 & .38 & .38 & .35 & .33 & .31 \\
\hline Trading revenue $\ldots \ldots \ldots \ldots$ & .16 & .15 & .17 & .17 & .15 & .19 & .21 & .20 & .16 & .16 \\
\hline Interest rate exposures $\ldots \ldots \ldots \ldots \ldots$ & n.a. & n.a. & .09 & .08 & .05 & .07 & .08 & .10 & .08 & .06 \\
\hline Foreign exchange rate exposures $\ldots \ldots$ & n.a. & n.a. & .06 & .08 & .09 & .09 & .08 & .07 & .07 & .07 \\
\hline Other commodity and equity exposures & n.a. & n.a. & .02 & $*$ & .01 & .03 & .04 & .03 & .01 & .02 \\
\hline 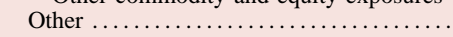 & 1.13 & 1.17 & 1.29 & 1.32 & 1.49 & 1.69 & 1.61 & 1.56 & 1.61 & 1.63 \\
\hline Non-interest expense $\ldots \ldots \ldots \ldots \ldots \ldots$ & 3.75 & 3.64 & 3.71 & 3.61 & 3.77 & 3.76 & 3.66 & 3.57 & 3.47 & 3.35 \\
\hline Salaries, wages, and employee benefits & 1.58 & 1.54 & 1.55 & 1.53 & 1.55 & 1.58 & 1.51 & 1.49 & 1.51 & 1.50 \\
\hline 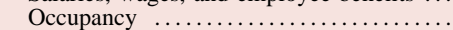 & .49 & .48 & .48 & .47 & .47 & .48 & .45 & .44 & .44 & .43 \\
\hline 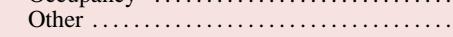 & 1.68 & 1.62 & 1.69 & 1.62 & 1.75 & 1.70 & 1.70 & 1.64 & 1.52 & 1.43 \\
\hline Net non-interest expense...$\ldots \ldots \ldots$. & 1.75 & 1.62 & 1.53 & 1.38 & 1.36 & 1.11 & 1.07 & 1.04 & .93 & .82 \\
\hline Gains on investment account securities $\ldots$ & -.01 & .01 & .03 & .04 & .06 & $*$ & -.04 & .07 & .10 & .08 \\
\hline Income before taxes and extraordinary items & 1.73 & 1.81 & 1.85 & 1.92 & 1.80 & 2.02 & 1.81 & 1.76 & 1.97 & 2.05 \\
\hline Taxes $\ldots \ldots \ldots$ & .58 & .63 & .65 & .68 & .62 & .72 & $\begin{array}{r}1.01 \\
.63\end{array}$ & .59 & .65 & .67 \\
\hline Extraordinary items, net of income taxes & $*$ & $*$ & * & $*$ & .01 & $*$ & $*$ & -.01 & $*$ & .01 \\
\hline Net income $\ldots \ldots \ldots \ldots .$. & 1.15 & 1.18 & 1.20 & 1.25 & 1.19 & 1.31 & 1.18 & 1.17 & 1.32 & 1.39 \\
\hline Cash dividends declared & .73 & .75 & .90 & .90 & .80 & .96 & .89 & .87 & 1.01 & 1.07 \\
\hline Retained income ....... & .42 & .43 & .30 & .35 & $\begin{array}{l}.00 \\
.39\end{array}$ & .35 & $\begin{array}{l}.07 \\
.29\end{array}$ & $\begin{array}{l}.01 \\
.30\end{array}$ & .30 & .31 \\
\hline Mемо: Return on equity . & 14.63 & 14.69 & 14.53 & 14.84 & 14.05 & 15.39 & 13.97 & 13.35 & 14.41 & 15.34 \\
\hline
\end{tabular}

* In absolute value, less than 0.005 percent.

n.a. Not available. MMDA Money market deposit account. RP Repurchase agreement. CD Certificate of deposit.

1. Includes allocated transfer risk reserves.

2. As in the Call Report, equity securities were combined with "other debt securities" before 1989.

3. Before 1994, the netted value of revaluation gains and losses appeared in "trading account securities"

if it was a gain and in "other non-interest-bearing liabilities" if it was a loss.

4. When possible, based on the average of quarterly balance sheet data reported on schedule RC-K of the quarterly Call Reports.

5. Before 1997, large time open accounts included in other time deposits.

6. Includes provisions for allocated transfer risk. 
A.2. Portfolio composition, interest rates, and income and expense, all U.S. banks, 1994-2003 B. Ten largest banks by assets

\begin{tabular}{|c|c|c|c|c|c|c|c|c|c|c|}
\hline Item & 1994 & 1995 & 1996 & 1997 & 1998 & 1999 & 2000 & 2001 & 2002 & 2003 \\
\hline & \multicolumn{10}{|c|}{ Balance sheet items as a percentage of average net consolidated assets } \\
\hline Interest-earning assets . & 77.26 & 77.12 & 80.12 & 81.84 & 81.25 & 81.49 & 82.23 & 81.74 & 81.68 & 81.35 \\
\hline Loans and leases, net $\ldots \ldots$ & 49.91 & 50.05 & 53.51 & 50.91 & 50.76 & 53.37 & 55.22 & 53.86 & 53.60 & 52.17 \\
\hline Commercial and industrial & 16.43 & 16.16 & 17.17 & 16.90 & 18.07 & 19.20 & 19.87 & 18.82 & 16.16 & 13.01 \\
\hline U.S. addressees ......... & 9.16 & 8.66 & 9.59 & 10.24 & 11.76 & 13.14 & 13.95 & 13.42 & 11.69 & 9.43 \\
\hline Foreign addressees $\ldots . .$. & 7.27 & 7.50 & 7.59 & 6.66 & 6.31 & 6.06 & 5.92 & 5.41 & 4.47 & 3.59 \\
\hline Consumer $\ldots \ldots \ldots \ldots$ & 6.59 & 6.60 & 6.22 & 6.40 & 6.04 & 5.94 & 5.43 & 6.17 & 7.82 & 7.96 \\
\hline Credit card . & 2.28 & 1.96 & 1.23 & 1.34 & 1.30 & 1.36 & 1.34 & 1.64 & 2.90 & 2.81 \\
\hline Installment and other & 4.31 & 4.65 & 4.99 & 5.06 & 4.74 & 4.58 & 4.09 & 4.53 & 4.92 & 5.15 \\
\hline Real estate ........... & 16.21 & 15.82 & 16.53 & 17.42 & 16.51 & 16.96 & 19.82 & 19.23 & 20.78 & 22.68 \\
\hline In domestic offices & 13.80 & 13.48 & 14.44 & 15.69 & 15.08 & 15.55 & 18.48 & 18.05 & 19.70 & 21.74 \\
\hline Construction and land development & .84 & .58 & .51 & .68 & .77 & .90 & .98 & 1.27 & 1.42 & 1.36 \\
\hline Farmland $\ldots \ldots \ldots \ldots \ldots \ldots \ldots \ldots$ & .06 & .06 & .06 & .09 & .09 & .10 & .11 & .11 & .12 & .10 \\
\hline One- to four-family residential ... & 9.69 & 9.62 & 10.43 & 11.02 & 10.33 & 10.77 & 13.37 & 12.41 & 13.51 & 16.03 \\
\hline Home equity $\ldots \ldots \ldots \ldots \ldots$ & 1.40 & 1.40 & 1.53 & 1.70 & 1.72 & 1.54 & 1.61 & 1.78 & 2.35 & 2.96 \\
\hline Other ........ & 8.29 & 8.22 & 8.90 & 9.31 & 8.61 & 9.22 & 11.76 & 10.63 & 11.17 & 13.07 \\
\hline Multifamily residential & .41 & .38 & .38 & .39 & .38 & .43 & .60 & .51 & .55 & .47 \\
\hline Nonfarm nonresidential & 2.79 & 2.83 & 3.05 & 3.52 & 3.51 & 3.35 & 3.42 & 3.76 & 4.09 & 3.78 \\
\hline In foreign offices $\ldots \ldots \ldots \ldots \ldots$ & 2.41 & 2.35 & 2.09 & 1.73 & 1.43 & 1.41 & 1.34 & 1.18 & 1.08 & .94 \\
\hline To depository institutions and acceptances & & & & & & & & & & \\
\hline 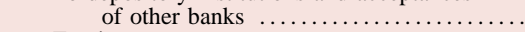 & 3.49 & 5.04 & 6.14 & 4.20 & 4.05 & 4.34 & 3.78 & 3.23 & 3.20 & 3.51 \\
\hline Foreign governments $\ldots \ldots \ldots \ldots$ & 1.27 & .90 & .69 & .45 & .35 & .38 & .28 & .20 & .20 & .17 \\
\hline Agricultural production & .25 & .21 & .23 & .31 & .28 & .26 & .23 & .28 & .23 & .19 \\
\hline Other loans .............. & 6.32 & 5.76 & 6.34 & 4.15 & 3.74 & 3.96 & 3.75 & 3.51 & 2.94 & 2.84 \\
\hline Lease-financing receivables ..... & 1.14 & 1.14 & 1.59 & 2.24 & 2.81 & 3.40 & 3.07 & 3.43 & 3.44 & 2.87 \\
\hline LESS: Unearned income on loans & -.16 & -.14 & -.11 & -.07 & -.06 & -.05 & -.04 & -.04 & -.08 & -.06 \\
\hline LESS: Loss reserves ${ }^{1} \ldots \ldots \ldots \ldots$ & -1.63 & -1.45 & -1.30 & -1.08 & -1.01 & -1.03 & -.97 & -.97 & -1.12 & -1.02 \\
\hline Securities ............ & 20.61 & 19.53 & 19.83 & 20.00 & 19.72 & 18.34 & 18.98 & 17.81 & 20.54 & 21.22 \\
\hline Investment account & 11.68 & 10.65 & 10.60 & 10.97 & 12.12 & 13.08 & 13.71 & 12.14 & 14.36 & 15.31 \\
\hline Debt .............. & 11.29 & 10.27 & 10.22 & 10.55 & 11.64 & 12.57 & 13.03 & 11.88 & 14.13 & 15.11 \\
\hline U.S. Treasury $\ldots \ldots \ldots \ldots \ldots$ & 2.06 & 2.03 & 1.93 & 1.56 & 1.70 & 1.98 & 1.96 & .68 & .59 & .82 \\
\hline U.S. government agency and & & & & & & & & & & \\
\hline corporation obligations $\ldots \ldots \ldots \ldots$ & 5.08 & 4.46 & 4.59 & 5.34 & 6.31 & 6.35 & 6.59 & 6.84 & 8.69 & 9.20 \\
\hline Government-backed mortgage pools & 2.79 & 2.89 & 3.58 & 4.26 & 5.13 & 5.03 & 4.88 & 4.99 & 6.38 & 7.59 \\
\hline Collateralized mortgage obligations . & 2.22 & 1.50 & .95 & .93 & .93 & .79 & .93 & 1.11 & 1.52 & .91 \\
\hline Other $\ldots \ldots \ldots \ldots \ldots \ldots \ldots \ldots \ldots \ldots$ & .06 & .08 & .06 & .15 & .26 & .52 & .78 & .74 & .79 & .70 \\
\hline State and local government $\ldots \ldots \ldots \ldots \ldots$ & .61 & .49 & .39 & .51 & .47 & .45 & .51 & .55 & .59 & .59 \\
\hline Private mortgage-backed securities ....... & .43 & .32 & .30 & .32 & .60 & .57 & .51 & .58 & .92 & 1.10 \\
\hline Other $\ldots \ldots \ldots \ldots \ldots \ldots \ldots \ldots \ldots \ldots$ & 3.03 & 2.97 & 3.01 & 2.81 & 2.57 & 3.22 & 3.47 & 3.22 & 3.34 & 3.40 \\
\hline Equity $^{2} \ldots \ldots$ & .39 & .38 & .38 & .42 & .47 & .51 & .68 & .26 & .22 & .20 \\
\hline Trading account $\ldots \ldots \ldots \ldots \ldots \ldots \ldots \ldots$ & 8.93 & 8.88 & 9.23 & 9.03 & 7.60 & 5.25 & 5.26 & 5.67 & 6.18 & 5.91 \\
\hline Gross federal funds sold and reverse RPs .. & 2.68 & 3.20 & 3.10 & 7.56 & 7.81 & 6.64 & 5.02 & 6.38 & 5.26 & 5.79 \\
\hline Interest-bearing balances at depositories .... & 4.05 & 4.34 & 3.68 & 3.37 & 2.96 & 3.14 & 3.01 & 3.69 & 2.28 & 2.18 \\
\hline Non-interest-earning assets $\ldots . . \ldots \ldots \ldots \ldots$ & 22.74 & 22.88 & 19.88 & 18.16 & 18.75 & 18.51 & 17.77 & 18.26 & 18.32 & 18.65 \\
\hline Revaluation gains held in trading accounts ${ }^{3}$ & 11.23 & 10.77 & 7.63 & 7.36 & 7.62 & 6.66 & 5.66 & 5.48 & 5.40 & 5.79 \\
\hline Other $\ldots \ldots \ldots \ldots \ldots \ldots \ldots \ldots \ldots \ldots \ldots \ldots \ldots \ldots \ldots \ldots \ldots$ & 11.51 & 12.11 & 12.25 & 10.80 & 11.13 & 11.85 & 12.11 & 12.78 & 12.93 & 12.86 \\
\hline Liabilities $\ldots \ldots \ldots \ldots \ldots \ldots$ & 93.42 & 93.59 & 93.04 & 92.61 & 92.58 & 92.28 & 92.36 & 92.14 & 91.53 & 91.94 \\
\hline Interest-bearing liabilities & 64.33 & 63.37 & 64.45 & 65.83 & 65.81 & 66.87 & 67.81 & 66.76 & 65.42 & 65.55 \\
\hline Deposits ................ & 48.20 & 47.49 & 47.87 & 47.36 & 47.65 & 48.79 & 49.27 & 49.09 & 48.96 & 49.01 \\
\hline In foreign offices .. & 26.10 & 28.36 & 26.41 & 22.18 & 20.17 & 21.04 & 21.62 & 19.22 & 16.27 & 15.68 \\
\hline In domestic offices $\ldots \ldots \ldots \ldots \ldots \ldots \ldots \ldots$ & 22.10 & 19.12 & 21.46 & 25.18 & 27.48 & 27.76 & 27.66 & 29.88 & 32.70 & 33.34 \\
\hline Other checkable deposits .... & 2.91 & 2.30 & 1.61 & 1.21 & .99 & .72 & .74 & .90 & .95 & 1.01 \\
\hline Savings (including MMDAs) & 12.70 & 10.56 & 12.31 & 14.26 & 15.83 & 16.84 & 16.73 & 19.23 & 22.81 & 24.22 \\
\hline Small-denomination time deposits $\ldots \ldots$ & 3.98 & 4.04 & 4.68 & 5.82 & 6.03 & 5.66 & 5.38 & 5.11 & 4.71 & 3.67 \\
\hline Large-denomination time deposits $\ldots \ldots$ & 2.51 & 2.23 & 2.86 & 3.89 & 4.62 & 4.54 & 4.80 & 4.63 & 4.22 & 4.43 \\
\hline Gross federal funds purchased and RPs $\ldots \ldots$ & 5.83 & 6.17 & 5.88 & 10.26 & 9.78 & 8.84 & 8.89 & 9.04 & 8.83 & 8.60 \\
\hline Other $\ldots \ldots \ldots \ldots \ldots \ldots \ldots \ldots \ldots$ & 10.29 & 9.71 & 10.69 & 8.20 & 8.37 & 9.24 & 9.65 & 8.62 & 7.64 & 7.93 \\
\hline Non-interest-bearing liabilities ........ & 29.09 & 30.22 & 28.59 & 26.78 & 26.77 & 25.41 & 24.56 & 25.38 & 26.10 & 26.40 \\
\hline Demand deposits in domestic offices .............. & 10.15 & 8.88 & 9.73 & 8.98 & 8.46 & 7.83 & 7.28 & 7.50 & 7.40 & 6.64 \\
\hline Revaluation losses held in trading accounts ${ }^{3}$ & 10.22 & 10.68 & 7.27 & 7.53 & 7.67 & 6.51 & 5.69 & 5.10 & 4.63 & 4.88 \\
\hline 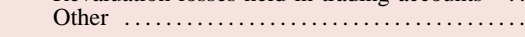 & 10.51 & 10.66 & 11.59 & 10.27 & 10.65 & 11.06 & 11.59 & 12.79 & 14.07 & 14.87 \\
\hline Capital account ... & 6.58 & 6.41 & 6.96 & 7.39 & 7.42 & 7.72 & 7.64 & 7.86 & 8.47 & 8.06 \\
\hline Мемо & & & & & & & & & & \\
\hline Commercial real estate loans & 4.65 & 4.40 & 4.65 & 5.45 & 5.61 & 5.69 & 5.87 & 6.68 & 6.92 & 6.31 \\
\hline Other real estate owned ................. & .58 & .27 & .18 & .13 & .09 & .06 & .04 & .04 & .03 & .03 \\
\hline Managed liabilities $\ldots \ldots \ldots \ldots \ldots \ldots \ldots$ & 46.21 & 47.94 & 47.39 & 46.02 & 44.42 & 45.49 & 46.84 & 43.41 & 38.90 & 38.69 \\
\hline $\begin{array}{l}\text { Average net consolidated assets } \\
\text { (billions of dollars) } \ldots \ldots \ldots\end{array}$ & 949 & 1,051 & 1,189 & 1,514 & 1,820 & 1,935 & 2,234 & 2,527 & 2,785 & 3,148 \\
\hline
\end{tabular}




\section{A.2.-Continued}

B. Ten largest banks by assets

\begin{tabular}{|c|c|c|c|c|c|c|c|c|c|c|}
\hline Item & 1994 & 1995 & 1996 & 1997 & 1998 & 1999 & 2000 & 2001 & 2002 & 2003 \\
\hline & \multicolumn{10}{|c|}{ Effective interest rate (percent) ${ }^{4}$} \\
\hline \multicolumn{11}{|l|}{ Rates earned } \\
\hline Interest-earning assets & 8.15 & 8.20 & 7.72 & 7.55 & 7.54 & 7.35 & 7.77 & 6.82 & 5.81 & 5.00 \\
\hline Taxable equivalent ... & 8.18 & 8.22 & 7.74 & 7.60 & 7.57 & 7.39 & 7.78 & 6.89 & 5.89 & 5.06 \\
\hline Loans and leases, gross $\ldots$ & 8.89 & 8.84 & 8.32 & 8.25 & 8.21 & 7.99 & 8.46 & 7.52 & 6.54 & 5.78 \\
\hline Net of loss provisions & 8.66 & 8.88 & 8.31 & 8.10 & 7.77 & 7.65 & 7.92 & 6.56 & 5.32 & 5.21 \\
\hline Securities .................. & 7.09 & 7.40 & 6.80 & 6.78 & 6.83 & 6.58 & 6.48 & 6.36 & 5.14 & 4.23 \\
\hline Taxable equivalent & 7.19 & 7.47 & 6.85 & 6.85 & $\begin{array}{l}6.03 \\
6.89\end{array}$ & 6.65 & 6.55 & 6.44 & 5.21 & 4.29 \\
\hline Investment account $\ldots \ldots \ldots \ldots \ldots \ldots$ & 6.57 & 7.04 & 6.70 & 6.76 & 6.78 & 6.59 & 6.40 & 6.23 & 5.30 & 4.26 \\
\hline \multicolumn{11}{|l|}{ U.S. Treasury securities and U.S. } \\
\hline (excluding MBS) …........... & n.a. & n.a. & n.a. & n.a. & n.a. & n.a. & n.a. & 5.01 & 3.74 & 2.62 \\
\hline Mortgage-backed securities & n.a. & n.a. & n.a. & n.a. & n.a. & n.a. & n.a. & 6.42 & 5.55 & 4.51 \\
\hline Other .................... & $\begin{array}{l}\text { n.a. } \\
\text { n.a. }\end{array}$ & 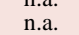 & $\begin{array}{l}\text { n.a. } \\
\text { n.a. }\end{array}$ & $\begin{array}{l}\text { n.a. } \\
\text { n.a. }\end{array}$ & $\begin{array}{l}\text { n.a. } \\
\text { n.a. }\end{array}$ & $\begin{array}{l}\text { n.a. } \\
\text { n.a. }\end{array}$ & $\begin{array}{l}\text { n.a. } \\
\text { n.a. }\end{array}$ & 6.34 & 5.30 & 4.28 \\
\hline Trading account $\ldots \ldots \ldots \ldots \ldots \ldots \ldots \ldots \ldots$ & 7.79 & 7.83 & 6.90 & 6.81 & 6.92 & 6.56 & 6.70 & 6.66 & 4.75 & 4.15 \\
\hline Gross federal funds sold and reverse RPs & 4.52 & 5.20 & 4.92 & 5.45 & 5.20 & 4.52 & 4.93 & 3.86 & 2.20 & 1.66 \\
\hline Interest-bearing balances at depositories & 7.27 & 7.15 & 6.71 & 6.91 & 7.16 & 7.22 & 7.43 & 3.73 & 3.40 & 2.49 \\
\hline \multicolumn{11}{|l|}{ Rates paid } \\
\hline Interest-bearing liabilities . & 5.43 & 5.88 & 5.44 & 5.41 & 5.29 & 4.79 & 5.37 & 4.09 & 2.55 & 1.86 \\
\hline Interest-bearing deposits & 4.32 & 4.99 & 4.57 & 4.54 & 4.40 & 3.82 & 4.40 & 3.27 & 1.95 & 1.36 \\
\hline In foreign offices ..... & 6.04 & 6.07 & 5.62 & 5.52 & 5.83 & 4.99 & 5.67 & 4.02 & 2.59 & 1.76 \\
\hline In domestic offices ........... & 2.35 & 3.42 & 3.32 & 3.69 & 3.39 & 3.04 & 3.51 & 2.85 & 1.68 & 1.20 \\
\hline Other checkable deposits ... & 1.10 & 1.29 & 1.32 & 1.97 & 1.67 & 1.44 & 1.61 & 1.67 & .93 & .87 \\
\hline Savings (including MMDAs) & 2.35 & 3.11 & 2.76 & 2.68 & 2.45 & 2.11 & 2.43 & 1.92 & 1.02 & .73 \\
\hline Large time deposits 5 ....... & 3.12 & 3.73 & 4.62 & 5.17 & 4.53 & 4.36 & 5.32 & 4.40 & 3.26 & 2.36 \\
\hline Other time deposits ${ }^{5} \ldots \ldots \ldots \ldots \ldots$ & 2.80 & 5.08 & 4.58 & 5.45 & 5.21 & 4.95 & 5.53 & 5.14 & 3.55 & 2.86 \\
\hline \multirow{3}{*}{$\begin{array}{l}\text { Gross federal funds purchased and RPs } \\
\text { Other interest-bearing liabilities ......... }\end{array}$} & 4.05 & 5.22 & 4.93 & 5.02 & 5.18 & 4.53 & 5.47 & 3.81 & 2.02 & 1.39 \\
\hline & 10.87 & 9.80 & 8.86 & 9.13 & 8.85 & 8.61 & 8.15 & $\begin{array}{l}3.01 \\
7.00\end{array}$ & 5.39 & 4.20 \\
\hline & \multicolumn{10}{|c|}{ Income and expense as a percentage of average net consolidated assets } \\
\hline Gross interest income. & 6.37 & 6.42 & 6.26 & 6.31 & 6.21 & 6.01 & 6.39 & 5.56 & 4.78 & 4.06 \\
\hline Taxable equivalent & 6.40 & 6.43 & 6.27 & 6.33 & 6.22 & 6.03 & 6.41 & 5.58 & 4.80 & 4.08 \\
\hline Loans $\ldots \ldots \ldots \ldots \ldots$ & 4.49 & 4.44 & 4.48 & 4.31 & 4.27 & 4.35 & 4.74 & 4.14 & 3.58 & 3.05 \\
\hline 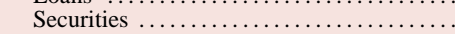 & .77 & .75 & .71 & .73 & .81 & .85 & .88 & .72 & .73 & .63 \\
\hline Gross federal funds sold and reverse RPs & .15 & .21 & .18 & .45 & .012 & .30 & .25 & .25 & .12 & .10 \\
\hline Other $\ldots \ldots \ldots \ldots \ldots \ldots \ldots \ldots \ldots \ldots \ldots$ & .97 & 1.00 & .88 & .82 & .70 & .51 & .51 & .43 & .34 & .27 \\
\hline Gross interest expense & 3.52 & 3.74 & 3.52 & 3.55 & 3.48 & 3.16 & 3.60 & 2.69 & 1.65 & 1.20 \\
\hline 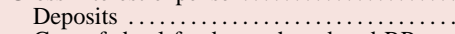 & 2.15 & 2.43 & 2.26 & 2.26 & 2.20 & 1.97 & 2.33 & 1.74 & 1.06 & .75 \\
\hline Gross federal funds purchased and RPs & .24 & .35 & .31 & .54 & .54 & .40 & .49 & .35 & .18 & .13 \\
\hline Other $\ldots \ldots \ldots \ldots \ldots \ldots \ldots \ldots \ldots \ldots$ & 1.13 & .95 & .95 & .75 & .74 & .79 & .78 & .59 & .41 & .33 \\
\hline $\begin{array}{l}\text { Net interest income ..... } \\
\text { Taxable equivalent }\end{array}$ & $\begin{array}{l}2.86 \\
2.88\end{array}$ & $\begin{array}{l}2.68 \\
2.70\end{array}$ & $\begin{array}{l}2.73 \\
2.75\end{array}$ & $\begin{array}{l}2.76 \\
2.79\end{array}$ & $\begin{array}{l}2.73 \\
2.75\end{array}$ & $\begin{array}{l}2.84 \\
2.86\end{array}$ & $\begin{array}{l}2.78 \\
2.80\end{array}$ & $\begin{array}{l}2.87 \\
2.89\end{array}$ & $\begin{array}{l}3.13 \\
3.15\end{array}$ & $\begin{array}{l}2.86 \\
2.88\end{array}$ \\
\hline Loss provisioning $6 \ldots$ & .26 & .11 & .11 & .16 & .31 & .26 & .38 & .59 & .73 & .35 \\
\hline Non-interest income & 2.33 & 2.16 & 2.34 & 2.12 & 2.15 & 2.55 & 2.54 & 2.23 & 2.32 & 2.31 \\
\hline Service charges on deposits & .26 & & & .32 & .33 & .37 & .40 & .44 & .48 & .46 \\
\hline $\begin{array}{l}\text { service charges on deposits } \\
\text { Fiduciary activities ........ }\end{array}$ & .20 & .30 & .31 & .34 & .32 & .31 & .27 & $\begin{array}{l}.44 \\
.29\end{array}$ & .26 & .27 \\
\hline Trading revenue $\ldots . . . . .$. & .53 & .46 & .52 & .43 & .33 & .46 & .48 & .43 & .32 & .30 \\
\hline Interest rate exposures & n.a. & n.a. & .30 & .23 & .10 & .17 & .20 & .21 & .15 & .12 \\
\hline 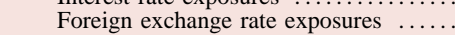 & n.a. & n.a. & .17 & .20 & .20 & .19 & .18 & .14 & .14 & .14 \\
\hline Other commodity and equity exposures. & $\begin{array}{l}\text { n.a. } \\
\text { n.a. }\end{array}$ & $\begin{array}{l}\text { n.a. } \\
\text { n.a. }\end{array}$ & .05 & $*$ & .03 & .09 & .11 & .08 & .03 & .04 \\
\hline Other $\ldots \ldots \ldots \ldots \ldots \ldots$ & 1.18 & 1.15 & 1.23 & 1.04 & 1.17 & 1.41 & 1.39 & 1.06 & 1.25 & 1.29 \\
\hline Non-interest expense $\ldots \ldots \ldots \ldots \ldots$ & 3.56 & 3.32 & 3.57 & 3.24 & 3.47 & 3.45 & 3.31 & 3.13 & 3.16 & 3.02 \\
\hline Salaries, wages, and employee benefits & 1.65 & 1.58 & 1.57 & 1.45 & 1.45 & 1.57 & 1.46 & 1.38 & 1.41 & 1.39 \\
\hline Occupancy $\ldots \ldots \ldots \ldots \ldots \ldots \ldots \ldots$ & .55 & .50 & .50 & .47 & .47 & .50 & .47 & .45 & .46 & .45 \\
\hline Other ....... & 1.36 & 1.24 & 1.50 & 1.33 & 1.54 & 1.38 & 1.39 & 1.30 & 1.28 & 1.18 \\
\hline Net non-interest expense & 1.23 & 1.16 & 1.23 & 1.12 & 1.32 & .90 & .77 & .90 & .84 & .71 \\
\hline Gains on investment account securities & .02 & .03 & .04 & .08 & .11 & .03 & -0.03 & .08 & .13 & .11 \\
\hline $\begin{array}{l}\text { Income before taxes and extraordinary items } \\
\text { Taxes }\end{array}$ & $\begin{array}{r}1.39 \\
48\end{array}$ & 1.44 & 1.44 & $\begin{array}{r}1.56 \\
58\end{array}$ & $\begin{array}{r}1.22 \\
44\end{array}$ & $\begin{array}{r}1.71 \\
66\end{array}$ & $\begin{array}{r}1.60 \\
60\end{array}$ & $\begin{array}{r}1.46 \\
48\end{array}$ & $\begin{array}{r}1.69 \\
57\end{array}$ & $\begin{array}{r}1.91 \\
62\end{array}$ \\
\hline Extraordinary items, net of income taxes & $\begin{array}{l}.48 \\
*\end{array}$ & $\begin{array}{l}.55 \\
*\end{array}$ & $\begin{array}{l}.52 \\
*\end{array}$ & $\begin{array}{l}.58 \\
*\end{array}$ & $\begin{array}{l}.44 \\
*\end{array}$ & ${ }^{.66}$ & .60 & $\begin{array}{r}.48 \\
-.01\end{array}$ & $* 3$ & $\begin{array}{l}.62 \\
*\end{array}$ \\
\hline Net income $\ldots \ldots \ldots \ldots \ldots \ldots \ldots \ldots \ldots \ldots \ldots \ldots \ldots$ & .91 & .88 & .92 & .98 & .78 & 1.05 & 1.00 & .97 & 1.12 & 1.29 \\
\hline Cash dividends declared & .58 & .57 & .70 & .82 & .53 & .79 & .86 & .66 & 1.05 & .99 \\
\hline Retained income ......... & .33 & .31 & .21 & .15 & .25 & .26 & .13 & .31 & .07 & .30 \\
\hline Мемо: Return on equity . & 13.86 & 13.78 & 13.21 & 13.22 & 10.53 & 13.58 & 13.04 & 12.34 & 13.24 & 16.01 \\
\hline
\end{tabular}

* In absolute value, less than 0.005 percent.

n.a. Not available. MMDA Money market deposit account. RP Repurchase agreement. CD Certificate of deposit.

1. Includes allocated transfer risk reserves.

2. As in the Call Report, equity securities were combined with "other debt securities" before 1989.

3. Before 1994, the netted value of revaluation gains and losses appeared in "trading account securities"

if it was a gain and in "other non-interest-bearing liabilities" if it was a loss.

4. When possible, based on the average of quarterly balance sheet data reported on schedule RC-K of the quarterly Call Reports.

5. Before 1997, large time open accounts included in other time deposits.

6. Includes provisions for allocated transfer risk. 
A.2. Portfolio composition, interest rates, and income and expense, all U.S. banks, 1994-2003 C. Banks ranked 11 through 100 by assets

\begin{tabular}{|c|c|c|c|c|c|c|c|c|c|c|}
\hline Item & 1994 & 1995 & 1996 & 1997 & 1998 & 1999 & 2000 & 2001 & 2002 & 2003 \\
\hline & \multicolumn{10}{|c|}{ Balance sheet items as a percentage of average net consolidated assets } \\
\hline Interest-earning assets . & 88.58 & 88.71 & 88.26 & 87.50 & 87.87 & 88.41 & 88.67 & 88.08 & 88.34 & 88.10 \\
\hline Loans and leases, net $\ldots \ldots$ & 58.56 & 62.68 & 64.24 & 63.89 & 64.38 & 64.23 & 64.88 & 62.14 & 60.00 & 59.48 \\
\hline Commercial and industrial & 18.04 & 19.26 & 18.95 & 19.01 & 18.92 & 19.40 & 18.19 & 15.84 & 13.27 & 11.96 \\
\hline U.S. addressees ......... & 16.99 & 18.10 & 17.71 & 17.78 & 17.59 & 18.18 & 17.64 & 15.36 & 12.94 & 11.66 \\
\hline Foreign addressees ... & 1.04 & 1.16 & 1.24 & 1.22 & 1.33 & 1.22 & .55 & .48 & .33 & .30 \\
\hline Consumer $\ldots \ldots \ldots \ldots$ & 12.62 & 14.23 & 15.67 & 15.62 & 14.52 & 13.57 & 13.79 & 13.20 & 12.79 & 12.57 \\
\hline Credit card . & 5.99 & 7.34 & 8.26 & 8.50 & 7.67 & 6.78 & 6.97 & 6.97 & 6.56 & 6.35 \\
\hline Installment and other & 6.63 & 6.89 & 7.40 & 7.12 & 6.86 & 6.79 & 6.82 & 6.23 & 6.22 & 6.21 \\
\hline Real estate ........... & 22.26 & 23.25 & 23.26 & 22.99 & 24.59 & 24.80 & 26.21 & 27.29 & 28.94 & 30.67 \\
\hline In domestic offices & 22.17 & 23.10 & 23.10 & 22.85 & 24.42 & 24.62 & 26.12 & 27.21 & 28.88 & 30.54 \\
\hline Construction and land development & 1.63 & 1.50 & 1.55 & 1.69 & 2.03 & 2.43 & 3.00 & 3.31 & 3.36 & 3.21 \\
\hline Farmland $\ldots \ldots \ldots \ldots \ldots \ldots \ldots \ldots$ & .14 & .13 & .13 & .14 & .17 & .19 & .22 & .23 & .22 & .20 \\
\hline One- to four-family residential ... & 12.98 & 14.16 & 14.15 & 13.88 & 14.86 & 14.15 & 14.51 & 15.51 & 17.05 & 18.79 \\
\hline Home equity $\ldots \ldots \ldots \ldots \ldots$ & 2.33 & 2.19 & 2.08 & 2.22 & 2.17 & 2.08 & 2.49 & 2.90 & 3.92 & 4.74 \\
\hline Other ........ & 10.65 & 11.97 & 12.07 & 11.65 & 12.69 & 12.07 & 12.02 & 12.60 & 13.13 & 14.04 \\
\hline Multifamily residential & .71 & .77 & .89 & .93 & 1.00 & 1.02 & 1.11 & 1.16 & 1.20 & 1.33 \\
\hline Nonfarm nonresidential & 6.72 & 6.54 & 6.37 & 6.21 & 6.36 & 6.82 & 7.28 & 6.99 & 7.05 & 7.01 \\
\hline In foreign offices $\ldots \ldots \ldots \ldots \ldots$ & .09 & .15 & .16 & .15 & .18 & .19 & .09 & .09 & .06 & .13 \\
\hline To depository institutions and acceptances & & & & & & & & & & \\
\hline 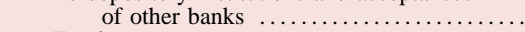 & 1.52 & 1.61 & 1.53 & 1.30 & 1.09 & .93 & 1.05 & 1.40 & 1.44 & 1.21 \\
\hline Foreign governments $\ldots \ldots \ldots \ldots \ldots$ & .28 & .20 & .20 & .09 & .06 & .06 & .03 & .03 & .02 & .02 \\
\hline Agricultural production & .29 & .26 & .28 & .29 & .33 & .33 & .37 & .32 & .27 & .23 \\
\hline Other loans .............. & 3.45 & 3.29 & 3.27 & 3.18 & 3.35 & 2.99 & 2.57 & 2.03 & 1.80 & 1.58 \\
\hline Lease-financing receivables ..... & 1.60 & 1.96 & 2.41 & 2.70 & 2.72 & 3.29 & 3.82 & 3.18 & 2.65 & 2.35 \\
\hline LESS: Unearned income on loans & -.07 & -.07 & -.06 & -.05 & -.04 & -.04 & -.03 & -.02 & -.02 & -.02 \\
\hline LESS: Loss reserves ${ }^{1} \ldots \ldots \ldots \ldots$ & -1.41 & -1.32 & -1.27 & -1.24 & -1.16 & -1.11 & -1.12 & -1.13 & -1.17 & -1.10 \\
\hline Securities ............ & 21.19 & 18.64 & 16.87 & 15.80 & 16.66 & 17.79 & 17.32 & 19.00 & 20.30 & 21.16 \\
\hline Investment account & 19.81 & 17.88 & 16.06 & 15.07 & 16.13 & 17.28 & 16.10 & 17.71 & 19.17 & 20.09 \\
\hline Debt .............. & 19.49 & 17.51 & 15.62 & 14.58 & 15.58 & 16.64 & 15.50 & 17.32 & 18.82 & 19.88 \\
\hline U.S. Treasury $\ldots \ldots \ldots \ldots \ldots$ & 6.86 & 4.82 & 3.34 & 2.81 & 2.25 & 1.70 & 1.12 & .67 & .74 & .95 \\
\hline \multicolumn{11}{|l|}{ U.S. government agency and } \\
\hline corporation obligations $\ldots \ldots \ldots \ldots$ & 9.37 & 9.40 & 9.12 & 8.98 & 9.93 & 10.57 & 9.70 & 10.09 & 11.45 & 12.99 \\
\hline Government-backed mortgage pools & 5.40 & 5.06 & 5.42 & 5.17 & 4.98 & 5.12 & 4.31 & 5.19 & 6.00 & 6.08 \\
\hline Collateralized mortgage obligations & 3.04 & 2.82 & 2.16 & 2.13 & 2.83 & 2.89 & 2.55 & 2.42 & 2.79 & 3.72 \\
\hline Other $\ldots \ldots \ldots \ldots \ldots \ldots \ldots \ldots \ldots \ldots \ldots$ & .94 & 1.51 & 1.54 & 1.68 & 2.12 & 2.56 & 2.84 & 2.48 & 2.65 & 3.19 \\
\hline State and local government $\ldots \ldots \ldots \ldots \ldots$ & 1.20 & 1.11 & .99 & .88 & .92 & .99 & .96 & .99 & .97 & .95 \\
\hline Private mortgage-backed securities ....... & .95 & 1.02 & 96 & .73 & .96 & 1.35 & 1.66 & 2.01 & 2.13 & 2.14 \\
\hline Other $\ldots \ldots \ldots \ldots \ldots \ldots \ldots \ldots \ldots \ldots$ & 1.22 & 1.16 & 1.21 & 1.18 & 1.53 & 2.02 & 2.06 & 3.56 & 3.53 & 2.85 \\
\hline Equity $^{2} \ldots \ldots$ & .32 & .37 & .44 & .49 & .55 & .65 & .60 & .39 & .34 & .21 \\
\hline Trading account & 1.38 & .76 & .80 & .73 & .54 & .51 & 1.22 & 1.29 & 1.13 & 1.07 \\
\hline Gross federal funds sold and reverse RPs .. & 5.11 & 4.52 & 4.26 & 4.38 & 3.57 & 3.34 & 3.76 & 4.06 & 4.71 & 4.21 \\
\hline Interest-bearing balances at depositories .... & 3.72 & 2.87 & 2.89 & 3.43 & 3.24 & 3.06 & 2.71 & 2.88 & 3.33 & 3.26 \\
\hline Non-interest-earning assets $\ldots \ldots \ldots \ldots \ldots \ldots \ldots$ & 11.42 & 11.29 & 11.74 & 12.50 & 12.13 & 11.59 & 11.33 & 11.92 & 11.66 & 11.90 \\
\hline Revaluation gains held in trading accounts ${ }^{3} \ldots \ldots$ & .60 & .50 & .51 & .69 & .75 & .56 & .40 & .55 & .47 & .60 \\
\hline Other $\ldots \ldots \ldots \ldots \ldots \ldots \ldots \ldots \ldots \ldots \ldots \ldots \ldots \ldots \ldots \ldots \ldots$ & 10.81 & 10.78 & 11.23 & 11.81 & 11.38 & 11.03 & 10.92 & 11.37 & 11.19 & 11.30 \\
\hline Liabilities $\ldots \ldots \ldots \ldots \ldots \ldots$ & 92.47 & 92.23 & 92.02 & 91.85 & 91.63 & 91.66 & 91.57 & 91.15 & 90.79 & 90.65 \\
\hline Interest-bearing liabilities & 72.85 & 74.05 & 73.14 & 72.60 & 73.40 & 74.97 & 76.46 & 75.98 & 74.70 & 73.22 \\
\hline Deposits ............... & 53.03 & 52.32 & 51.81 & 51.45 & 51.50 & 51.50 & 51.57 & 51.94 & 50.48 & 49.81 \\
\hline In foreign offices & 8.05 & 8.12 & 7.52 & 7.85 & 8.15 & 7.96 & 7.34 & 6.86 & 6.09 & 6.33 \\
\hline In domestic offices $\ldots \ldots \ldots$ & 44.98 & 44.20 & 44.30 & 43.60 & 43.35 & 43.53 & 44.23 & 45.08 & 44.39 & 43.48 \\
\hline Other checkable deposits .... & 6.91 & 5.62 & 3.06 & 1.95 & 1.75 & 1.60 & 1.32 & 1.20 & 1.17 & 1.33 \\
\hline Savings (including MMDAs) & 20.13 & 18.78 & 20.76 & 21.08 & 21.40 & 22.46 & 22.34 & 24.36 & 26.45 & 27.53 \\
\hline Small-denomination time deposits $\ldots \ldots$ & 13.26 & 14.24 & 14.09 & 13.43 & 12.84 & 11.85 & 11.80 & 10.66 & 8.78 & 7.47 \\
\hline Large-denomination time deposits $\ldots \ldots$ & 4.68 & 5.55 & 6.39 & 7.15 & 7.36 & 7.62 & 8.77 & 8.86 & 7.98 & 7.16 \\
\hline Gross federal funds purchased and RPs ... & 11.49 & 11.37 & 10.00 & 9.36 & 9.48 & 9.77 & 9.28 & 9.71 & 9.66 & 9.71 \\
\hline Other $\ldots \ldots \ldots \ldots \ldots \ldots \ldots \ldots \ldots$ & 8.34 & 10.36 & 11.32 & 11.79 & 12.43 & 13.70 & 15.61 & 14.32 & 14.55 & 13.70 \\
\hline Non-interest-bearing liabilities ........ & 19.62 & 18.18 & 18.89 & 19.24 & 18.23 & 16.70 & 15.12 & 15.17 & 16.09 & 17.43 \\
\hline Demand deposits in domestic offices .............. & 15.28 & 14.26 & 14.47 & 14.17 & 12.39 & 10.52 & 8.61 & 7.17 & 6.32 & 5.94 \\
\hline Revaluation losses held in trading accounts ${ }^{3}$ & .57 & .49 & .49 & .68 & .76 & .58 & .41 & .52 & .44 & .56 \\
\hline 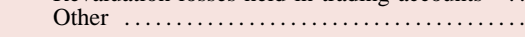 & 3.89 & 3.43 & 3.93 & 4.39 & 5.07 & 5.59 & 6.09 & 7.49 & 9.34 & 10.93 \\
\hline Capital account $\ldots$ & 7.53 & 7.77 & 7.98 & 8.15 & 8.37 & 8.34 & 8.43 & 8.85 & 9.21 & 9.35 \\
\hline Мемо & & & & & & & & & & \\
\hline Commercial real estate loans & 9.69 & 9.42 & 9.38 & 9.44 & 10.11 & 11.00 & 12.06 & 12.06 & 12.24 & 12.11 \\
\hline Other real estate owned ................. & .25 & .13 & .08 & .06 & .04 & .03 & .03 & .04 & .05 & .06 \\
\hline Managed liabilities...$\ldots \ldots \ldots \ldots \ldots \ldots$ & 32.89 & 35.68 & 35.60 & 36.60 & 38.11 & 39.83 & 41.98 & 40.81 & 39.48 & 38.15 \\
\hline $\begin{array}{l}\text { Average net consolidated assets } \\
\text { (billions of dollars) } \ldots \ldots \ldots\end{array}$ & 1,204 & 1,338 & 1,450 & 1,604 & 1,745 & 1,881 & 2,031 & 2,130 & 2,124 & 2,287 \\
\hline
\end{tabular}




\section{A.2.-Continued}

C. Banks ranked 11 through 100 by assets

\begin{tabular}{|c|c|c|c|c|c|c|c|c|c|c|}
\hline Item & 1994 & 1995 & 1996 & 1997 & 1998 & 1999 & 2000 & 2001 & 2002 & 2003 \\
\hline & \multicolumn{10}{|c|}{ Effective interest rate (percent) ${ }^{4}$} \\
\hline \multicolumn{11}{|l|}{ Rates earned } \\
\hline Interest-earning assets .. & 7.29 & 8.31 & 8.16 & 8.31 & 8.10 & 7.84 & 8.46 & 7.53 & 6.00 & 5.26 \\
\hline Taxable equivalent ... & 7.36 & 8.37 & 8.23 & 8.36 & 8.17 & 7.88 & 8.48 & 7.58 & 6.07 & 5.33 \\
\hline Loans and leases, gross ... & 8.22 & 9.10 & 8.88 & 9.03 & 8.82 & 8.50 & 9.14 & 8.26 & 6.80 & 6.11 \\
\hline Net of loss provisions & 7.87 & 8.67 & 8.21 & 8.27 & 8.15 & 7.80 & 8.25 & 6.96 & 5.59 & 5.11 \\
\hline Securities.$\ldots \ldots \ldots \ldots \ldots$ & 5.75 & 6.38 & 6.49 & 6.55 & 6.31 & 6.32 & 6.64 & 5.96 & 4.79 & 3.80 \\
\hline Taxable equivalent & 5.92 & 6.56 & 6.66 & 6.70 & 6.46 & 6.46 & 6.77 & 6.08 & 4.91 & 3.91 \\
\hline Investment account $\ldots \ldots \ldots \ldots \ldots \ldots$ & 5.75 & 6.35 & 6.49 & 6.57 & 6.33 & 6.34 & 6.66 & 6.04 & 4.86 & 3.87 \\
\hline \multicolumn{10}{|l|}{ U.S. Treasury securities and U.S. } & 3.17 \\
\hline Mortgage-backed securities $\ldots \ldots \ldots$ & $\begin{array}{l}\text { In.a. } \\
\text { n.a. }\end{array}$ & $\begin{array}{l}11 . \mathrm{a} . \\
\text { n.a. }\end{array}$ & $\begin{array}{l}\text { n.a. } \\
\text { n.a. }\end{array}$ & $\begin{array}{l}\text { n.a. } \\
\text { n.a. }\end{array}$ & $\begin{array}{l}\text { 11.a. } \\
\text { n.a. }\end{array}$ & $\begin{array}{l}\text { n.a. } \\
\text { n.a. }\end{array}$ & $\begin{array}{l}\text { n.a. } \\
\text { n.a. }\end{array}$ & $\begin{array}{l}5.83 \\
6.60\end{array}$ & $\begin{array}{l}4.28 \\
5.34\end{array}$ & $\begin{array}{l}3.17 \\
4.20\end{array}$ \\
\hline Other $\ldots \ldots \ldots \ldots \ldots$ & n.a. & n.a. & $\begin{array}{l}\text { II.a. } \\
\text { n.a. }\end{array}$ & $\begin{array}{l}\text { II.a. } \\
\text { n.a. }\end{array}$ & n.a. & $\begin{array}{l}\text { n.a. } \\
\text { n.a. }\end{array}$ & $\begin{array}{l}\text { II.a. } \\
\text { n.a. }\end{array}$ & 5.13 & 4.22 & 3.61 \\
\hline Trading account $\ldots \ldots \ldots \ldots \ldots \ldots \ldots \ldots$ & 5.75 & 7.27 & 6.53 & 6.05 & 5.86 & 5.58 & 6.25 & 4.83 & 3.59 & 2.62 \\
\hline Gross federal funds sold and reverse RPs & 4.31 & 5.91 & 5.31 & 5.45 & 5.46 & 5.12 & 6.06 & 3.86 & 1.68 & 1.14 \\
\hline Interest-bearing balances at depositories .. & 4.69 & 6.78 & 5.82 & 5.76 & 5.67 & 4.81 & 5.49 & 4.38 & 2.46 & 1.93 \\
\hline \multicolumn{11}{|l|}{ Rates paid } \\
\hline Interest-bearing liabilities. & 3.71 & 4.94 & 4.70 & 4.79 & 4.77 & 4.38 & 5.22 & 4.16 & 2.41 & 1.79 \\
\hline Interest-bearing deposits & 3.25 & 4.35 & 4.15 & 4.22 & 4.15 & 3.76 & 4.42 & 3.60 & 1.96 & 1.35 \\
\hline In foreign offices .... & 4.60 & 6.30 & 5.29 & 5.23 & 5.22 & 4.70 & 5.38 & 3.67 & 1.70 & 1.22 \\
\hline In domestic offices $. . . . \ldots . .$. & 3.03 & 4.01 & 3.96 & 4.04 & 3.96 & 3.60 & 4.26 & 3.60 & 1.99 & 1.37 \\
\hline Other checkable deposits & 1.61 & 1.89 & 1.78 & 2.01 & 2.41 & 2.03 & 2.57 & 2.32 & .94 & .67 \\
\hline Savings (including MMDAs) . & 2.46 & 3.10 & 2.91 & 2.84 & 2.76 & 2.49 & 2.94 & 2.30 & 1.08 & .66 \\
\hline Large time deposits 5 ........ & 4.21 & 5.70 & 5.50 & 5.47 & 5.32 & 4.96 & 5.88 & 5.11 & 3.36 & 2.70 \\
\hline Other time deposits ${ }^{5} \quad \ldots \ldots \ldots \ldots$ & 4.17 & 5.35 & 5.26 & 5.43 & 5.35 & 5.03 & 5.73 & 5.42 & 3.68 & 2.95 \\
\hline Gross federal funds purchased and RPs .. & 4.28 & 5.86 & 5.19 & 5.29 & 5.22 & 4.87 & 6.02 & 3.86 & 1.73 & 1.20 \\
\hline \multirow[t]{2}{*}{ Other interest-bearing liabilities ........... } & 5.24 & 6.43 & 5.95 & 5.85 & 5.81 & 5.41 & 6.36 & 5.30 & 3.54 & 3.01 \\
\hline & \multicolumn{10}{|c|}{ Income and expense as a percentage of average net consolidated assets } \\
\hline Gross interest income . & 6.46 & 7.40 & 7.24 & 7.26 & 7.16 & 6.98 & 7.54 & 6.70 & 5.31 & 4.67 \\
\hline Taxable equivalent & 6.51 & 7.45 & 7.28 & 7.30 & 7.19 & $\begin{array}{l}0.90 \\
7.02\end{array}$ & 7.57 & 6.73 & 5.34 & 4.70 \\
\hline Loans $. . . \ldots \ldots \ldots . . .$. & 4.91 & 5.79 & 5.80 & 5.87 & 5.79 & 5.56 & 6.05 & 5.28 & 4.15 & 3.72 \\
\hline 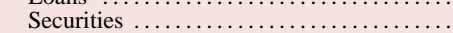 & 1.13 & 1.13 & 1.03 & .98 & 1.00 & 1.10 & 1.09 & 1.06 & .90 & .75 \\
\hline Gross federal funds sold and reverse RPs & .21 & .27 & .23 & .22 & .19 & .18 & .22 & .15 & .08 & .04 \\
\hline 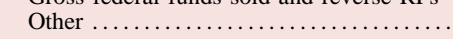 & .21 & .21 & .18 & .19 & .18 & .14 & .18 & .15 & .00 & .08 \\
\hline Gross interest expense & 2.67 & 3.62 & 3.39 & 3.41 & 3.45 & 3.26 & 3.96 & 3.14 & 1.77 & 1.30 \\
\hline Deposits ........... & 1.73 & 2.29 & 2.18 & 2.23 & 2.23 & 2.02 & 2.41 & 2.01 & 1.09 & .77 \\
\hline Gross federal funds purchased and RPs & .51 & .67 & .55 & .51 & .51 & .51 & .56 & .38 & .17 & .12 \\
\hline Other $\ldots \ldots \ldots \ldots \ldots \ldots \ldots \ldots \ldots \ldots \ldots$ & .43 & .66 & .66 & .68 & .71 & .74 & .99 & .75 & .51 & .41 \\
\hline Net interest income .... & 3.79 & 3.78 & 3.84 & 3.85 & 3.71 & 3.72 & 3.58 & 3.56 & 3.54 & 3.37 \\
\hline Taxable equivalent & 3.84 & 3.84 & 3.89 & 3.89 & 3.74 & 3.75 & 3.61 & 3.59 & 3.57 & 3.40 \\
\hline Loss provisioning 6 & .32 & .39 & .54 & .60 & .54 & .55 & 68 & .91 & .80 & 67 \\
\hline Non-interest income $\ldots \ldots \ldots \ldots$ & 2.25 & 2.38 & 2.61 & 2.76 & 3.07 & 3.36 & 3.18 & 3.36 & 3.30 & 3.28 \\
\hline Service charges on deposits & .45 & .44 & .44 & .44 & .42 & .41 & .42 & .42 & .42 & .42 \\
\hline Fiduciary activities $\ldots \ldots \ldots \ldots$. & .39 & .40 & .43 & .44 & .49 & .48 & .52 & .42 & .42 & .37 \\
\hline Trading income $\ldots \ldots \ldots \ldots$ & .08 & .09 & .08 & .08 & .09 & .08 & .07 & .08 & .08 & .09 \\
\hline Interest rate exposures $\ldots \ldots \ldots \ldots \ldots$ & n.a. & n.a. & .03 & .02 & .03 & .02 & .02 & .04 & .04 & .04 \\
\hline Foreign exchange rate exposures $\ldots \ldots$ & n.a. & n.a. & .04 & .05 & .06 & .05 & .04 & .03 & .04 & .04 \\
\hline Other commodity and equity exposures & n.a. & n.a. & .01 & $*$ & $*$ & $*$ & $*$ & $*$ & $* 4$ & .01 \\
\hline 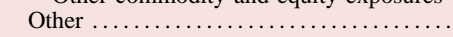 & 1.33 & 1.45 & 1.67 & 1.79 & 2.07 & 2.39 & 2.18 & 2.44 & 2.37 & 2.40 \\
\hline Non-interest expense $\ldots \ldots \ldots \ldots \ldots \ldots$ & 3.86 & 3.79 & 3.85 & 3.85 & 4.03 & 4.12 & 4.00 & 3.95 & 3.73 & 3.63 \\
\hline Salaries, wages, and employee benefits & 1.50 & 1.47 & 1.51 & 1.51 & 1.53 & 1.53 & 1.44 & 1.47 & 1.49 & 1.47 \\
\hline Occupancy $\ldots \ldots \ldots \ldots \ldots \ldots \ldots$ & .47 & .47 & .48 & .46 & .46 & .45 & .43 & .42 & .40 & .41 \\
\hline 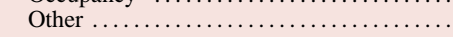 & 1.89 & 1.85 & 1.86 & 1.88 & 2.04 & 2.14 & 2.14 & 2.07 & 1.84 & 1.76 \\
\hline Net non-interest expense...$\ldots \ldots \ldots$. & 1.61 & 1.41 & 1.24 & 1.10 & .96 & .76 & .82 & .59 & .43 & .35 \\
\hline Gains on investment account securities ... & -.01 & .02 & .02 & .02 & .03 & -.01 & -.05 & .09 & .10 & .06 \\
\hline Income before taxes and extraordinary items & 1.85 & 2.01 & 2.09 & 2.18 & 2.24 & 2.40 & 2.02 & 2.15 & 2.41 & 2.41 \\
\hline Taxes $\ldots \ldots \ldots \ldots \ldots \ldots \ldots$ & .63 & $\begin{array}{r}2.01 \\
.70\end{array}$ & .75 & .77 & .78 & .86 & $\begin{array}{r}2.02 \\
.70\end{array}$ & .74 & .82 & $\begin{array}{r}2.41 \\
.82\end{array}$ \\
\hline Extraordinary items, net of income taxes & * & $*$ & $*$ & $*$ & $*$ & $*$ & $*$ & $*$ & * & * $* 2$ \\
\hline Net income $\ldots \ldots \ldots \ldots \ldots \ldots \ldots \ldots \ldots$ & 1.22 & 1.31 & 1.34 & 1.42 & 1.45 & 1.54 & 1.32 & 1.40 & 1.59 & 1.59 \\
\hline Cash dividends declared & .86 & .85 & 1.07 & .93 & .96 & 1.16 & .94 & .96 & .99 & 1.05 \\
\hline Retained income ....... & .36 & .46 & .26 & .48 & .50 & $\begin{array}{r}1.10 \\
.38\end{array}$ & .38 & .44 & .60 & .54 \\
\hline Mемо: Return on equity . & 16.27 & 16.84 & 16.78 & 17.36 & 17.38 & 18.46 & 15.72 & 15.79 & 17.26 & 17.01 \\
\hline
\end{tabular}

* In absolute value, less than 0.005 percent.

n.a. Not available. MMDA Money market deposit account. RP Repurchase agreement. CD Certificate of deposit.

1. Includes allocated transfer risk reserves.

2. As in the Call Report, equity securities were combined with "other debt securities" before 1989.

3. Before 1994, the netted value of revaluation gains and losses appeared in "trading account securities"

if it was a gain and in "other non-interest-bearing liabilities" if it was a loss.

4. When possible, based on the average of quarterly balance sheet data reported on schedule RC-K of the quarterly Call Reports.

5. Before 1997, large time open accounts included in other time deposits.

6. Includes provisions for allocated transfer risk. 
A.2. Portfolio composition, interest rates, and income and expense, all U.S. banks, 1994-2003 D. Banks ranked 101 through 1,000 by assets

\begin{tabular}{|c|c|c|c|c|c|c|c|c|c|c|}
\hline Item & 1994 & 1995 & 1996 & 1997 & 1998 & 1999 & 2000 & 2001 & 2002 & 2003 \\
\hline & \multicolumn{10}{|c|}{ Balance sheet items as a percentage of average net consolidated assets } \\
\hline Interest-earning assets . & 90.89 & 90.97 & 91.10 & 91.32 & 91.36 & 91.68 & 91.50 & 91.16 & 91.36 & 91.34 \\
\hline Loans and leases, net $\ldots \ldots$ & 59.71 & 62.18 & 62.63 & 62.22 & 61.13 & 61.49 & 62.15 & 62.46 & 61.46 & 61.33 \\
\hline Commercial and industrial & 12.08 & 12.70 & 12.79 & 12.43 & 12.48 & 12.64 & 12.95 & 13.03 & 12.38 & 11.52 \\
\hline U.S. addressees ......... & 11.92 & 12.54 & 12.61 & 12.19 & 12.16 & 12.32 & 12.60 & 12.65 & 12.06 & 11.21 \\
\hline Foreign addressees $\ldots . .$. & .16 & .16 & .18 & .23 & .32 & .32 & .35 & .38 & .31 & .31 \\
\hline Consumer $\ldots \ldots \ldots \ldots$ & 15.75 & 16.25 & 15.88 & 14.03 & 12.28 & 10.79 & 10.19 & 9.76 & 8.13 & 6.80 \\
\hline Credit card . & 5.95 & 6.30 & 6.66 & 5.52 & 4.48 & 3.37 & 3.27 & 3.61 & 2.64 & 1.82 \\
\hline Installment and other & 9.80 & 9.95 & 9.22 & 8.52 & 7.80 & 7.41 & 6.92 & 6.15 & 5.50 & 4.97 \\
\hline Real estate ........... & 29.45 & 30.82 & 31.37 & 33.23 & 33.94 & 35.90 & 36.94 & 37.64 & 38.92 & 40.96 \\
\hline In domestic offices & 29.43 & 30.80 & 31.34 & 33.21 & 33.92 & 35.88 & 36.91 & 37.62 & 38.90 & 40.91 \\
\hline Construction and land development & 2.08 & 2.21 & 2.38 & 2.69 & 2.88 & 3.49 & 4.15 & 4.90 & 5.40 & 5.90 \\
\hline Farmland $\ldots \ldots \ldots \ldots \ldots \ldots \ldots \ldots$ & .36 & .40 & .46 & .53 & .56 & .58 & .65 & .66 & .73 & .80 \\
\hline One- to four-family residential & 16.27 & 17.50 & 17.34 & 18.14 & 18.19 & 18.26 & 17.17 & 16.18 & 15.39 & 15.71 \\
\hline Home equity $\ldots \ldots \ldots \ldots \ldots$ & 2.33 & 2.37 & 2.30 & 2.30 & 2.15 & 1.99 & 2.10 & 2.21 & 2.51 & 2.92 \\
\hline Other ........ & 13.94 & 15.14 & 15.03 & 15.84 & 16.05 & 16.27 & 15.06 & 13.97 & 12.88 & 12.79 \\
\hline Multifamily residential & 1.13 & 1.21 & 1.29 & 1.29 & 1.26 & 1.44 & 1.58 & 1.69 & 1.83 & 2.00 \\
\hline Nonfarm nonresidential & 9.58 & 9.48 & 9.87 & 10.56 & 11.03 & 12.12 & 13.36 & 14.18 & 15.55 & 16.51 \\
\hline In foreign offices $\ldots \ldots \ldots \ldots \ldots \ldots \ldots$ & .03 & .02 & .02 & .02 & .02 & .02 & .02 & .02 & .03 & .05 \\
\hline To depository institutions and acceptances & & & & & & & & & & \\
\hline 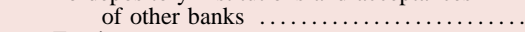 & .42 & .36 & .50 & .59 & .53 & .46 & .37 & .38 & .37 & .37 \\
\hline Foreign governments $\ldots \ldots \ldots \ldots \ldots$ & .02 & .02 & .02 & .02 & .03 & .03 & .03 & .03 & .02 & .02 \\
\hline Agricultural production & .62 & .69 & .71 & .74 & .80 & .78 & .82 & .85 & .86 & .83 \\
\hline Other loans .............. & 1.98 & 1.78 & 1.68 & 1.47 & 1.30 & 1.25 & 1.22 & 1.22 & 1.18 & 1.22 \\
\hline Lease-financing receivables ..... & .83 & .90 & 1.01 & .99 & .99 & .78 & .75 & .74 & .76 & .69 \\
\hline LESS: Unearned income on loans & -.15 & -.12 & -.10 & -.10 & -.09 & -.08 & -.08 & -.07 & -.06 & -.06 \\
\hline LESS: Loss reserves ${ }^{1} \ldots \ldots \ldots \ldots$ & -1.30 & -1.22 & -1.22 & -1.18 & -1.13 & -1.06 & -1.04 & -1.12 & -1.10 & -1.02 \\
\hline Securities ............ & 25.74 & 23.09 & 22.67 & 23.45 & 24.26 & 25.17 & 24.34 & 22.81 & 23.86 & 24.36 \\
\hline Investment account & 25.43 & 22.88 & 22.55 & 23.35 & 24.15 & 25.09 & 24.25 & 22.70 & 23.80 & 24.22 \\
\hline Debt .............. & 24.99 & 22.42 & 22.03 & 22.74 & 23.46 & 24.33 & 23.46 & 22.27 & 23.30 & 23.79 \\
\hline U.S. Treasury $\ldots \ldots \ldots \ldots \ldots$ & 8.18 & 6.48 & 5.61 & 4.96 & 3.92 & 2.53 & 1.80 & 1.32 & 1.22 & 1.00 \\
\hline U.S. government agency and & & & & & & & & & & \\
\hline corporation obligations $\ldots \ldots \ldots \ldots$ & 12.77 & 12.23 & 12.66 & 13.97 & 15.13 & 16.29 & 15.56 & 14.70 & 15.85 & 16.96 \\
\hline Government-backed mortgage pools & 5.64 & 5.42 & 5.69 & 6.22 & 6.46 & 6.72 & 6.22 & 6.27 & 6.55 & 7.03 \\
\hline Collateralized mortgage obligations . & 4.34 & 3.56 & 3.12 & 3.01 & 3.22 & 3.52 & 3.04 & 3.08 & 3.69 & 3.69 \\
\hline Other $\ldots \ldots \ldots \ldots \ldots \ldots \ldots \ldots \ldots \ldots \ldots$ & 2.79 & 3.25 & 3.85 & 4.73 & 5.44 & 6.05 & 6.30 & 5.35 & 5.60 & 6.24 \\
\hline State and local government $\ldots \ldots \ldots \ldots \ldots$ & 2.30 & 2.13 & 2.24 & 2.44 & 2.70 & 2.91 & 2.91 & 2.90 & 2.89 & 2.95 \\
\hline Private mortgage-backed securities ........ & .73 & .68 & .76 & .59 & .65 & 1.00 & .99 & .94 & .99 & .87 \\
\hline Other $\ldots \ldots \ldots \ldots \ldots \ldots \ldots \ldots \ldots \ldots$ & .99 & .89 & .76 & .78 & 1.06 & 1.60 & 2.19 & 2.42 & 2.34 & 2.01 \\
\hline Equity $^{2} \ldots \ldots$ & .43 & .47 & .52 & .61 & .69 & .77 & .80 & .43 & .50 & .43 \\
\hline 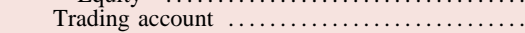 & .31 & .20 & .12 & .10 & .11 & .08 & .09 & .11 & .06 & .14 \\
\hline Gross federal funds sold and reverse RPs .. & 3.64 & 3.92 & 3.87 & 3.60 & 4.17 & 3.35 & 3.40 & 4.20 & 4.15 & 3.85 \\
\hline Interest-bearing balances at depositories ... & 1.79 & 1.78 & 1.93 & 2.05 & 1.80 & 1.68 & 1.60 & 1.68 & 1.89 & 1.81 \\
\hline Non-interest-earning assets $\ldots \ldots \ldots \ldots \ldots \ldots \ldots$ & 9.11 & 9.03 & 8.90 & 8.68 & 8.64 & 8.32 & 8.50 & 8.84 & 8.64 & 8.66 \\
\hline Revaluation gains held in trading accounts ${ }^{3}$ & .02 & .05 & .02 & * & * & .01 & .02 & .01 & .01 & $*$ \\
\hline 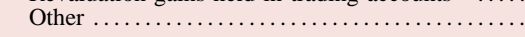 & 9.09 & 8.99 & 8.88 & 8.68 & 8.63 & 8.31 & 8.49 & 8.84 & 8.64 & 8.65 \\
\hline Liabilities $\ldots \ldots \ldots \ldots \ldots \ldots$ & 91.62 & 91.36 & 91.06 & 90.78 & 90.55 & 90.90 & 90.95 & 90.32 & 89.93 & 89.69 \\
\hline Interest-bearing liabilities & 74.76 & 75.00 & 75.06 & 75.19 & 75.42 & 76.76 & 77.43 & 77.01 & 76.35 & 75.79 \\
\hline Deposits ............... & 60.45 & 59.68 & 59.98 & 61.47 & 62.40 & 61.94 & 62.67 & 63.10 & 62.83 & 61.95 \\
\hline In foreign offices & 1.69 & 1.71 & 1.33 & 1.23 & 1.31 & 1.20 & 1.27 & 1.23 & .88 & .64 \\
\hline In domestic offices & 58.75 & 57.97 & 58.65 & 60.25 & 61.09 & 60.74 & 61.40 & 61.86 & 61.95 & 61.31 \\
\hline Other checkable deposits .... & 9.72 & 8.54 & 6.21 & 4.96 & 4.23 & 3.75 & 3.32 & 3.25 & 3.32 & 3.55 \\
\hline Savings (including MMDAs) & 22.94 & 20.75 & 22.49 & 23.59 & 25.65 & 27.35 & 27.03 & 27.67 & 30.17 & 31.42 \\
\hline Small-denomination time deposits $\ldots \ldots$ & 19.31 & 21.12 & 21.61 & 22.03 & 21.22 & 19.61 & 19.44 & 18.80 & 16.83 & 15.04 \\
\hline Large-denomination time deposits $\ldots \ldots$ & 6.79 & 7.56 & 8.34 & 9.66 & 9.99 & 10.03 & 11.61 & 12.14 & 11.63 & 11.29 \\
\hline Gross federal funds purchased and RPs ...... & 8.46 & 8.31 & 8.19 & 7.09 & 6.16 & 6.90 & 6.30 & 5.76 & 5.27 & 5.35 \\
\hline Other $\ldots \ldots \ldots \ldots \ldots \ldots \ldots \ldots \ldots$ & 5.86 & 7.00 & 6.88 & 6.62 & 6.86 & 7.92 & 8.45 & 8.15 & 8.25 & 8.49 \\
\hline Non-interest-bearing liabilities ........ & 16.86 & 16.36 & 16.00 & 15.60 & 15.13 & 14.15 & 13.52 & 13.31 & 13.58 & 13.90 \\
\hline Demand deposits in domestic offices .............. & 14.59 & 14.07 & 13.84 & 13.15 & 11.90 & 10.19 & 8.97 & 8.23 & 8.05 & 7.97 \\
\hline Revaluation losses held in trading accounts ${ }^{3}$ & .02 & .05 & .02 & .01 & .01 & .01 & $*$ & .01 & .01 & $*$ \\
\hline Other $\ldots \ldots \ldots \ldots \ldots \ldots \ldots \ldots \ldots \ldots \ldots \ldots \ldots \ldots$ & 2.26 & 2.24 & 2.14 & 2.44 & 3.22 & 3.95 & 4.55 & 5.08 & 5.52 & 5.93 \\
\hline Capital account $\ldots$ & 8.38 & 8.64 & 8.94 & 9.22 & 9.45 & 9.10 & 9.05 & 9.68 & 10.07 & 10.31 \\
\hline Мемо & & & & & & & & & & \\
\hline Commercial real estate loans & 13.06 & 13.19 & 13.83 & 14.77 & 15.38 & 17.28 & 19.32 & 21.03 & 23.05 & 24.62 \\
\hline Other real estate owned ................. & .28 & .17 & .13 & .11 & .09 & .08 & .07 & .08 & .10 & .11 \\
\hline Managed liabilities $\ldots \ldots \ldots \ldots \ldots \ldots \ldots$ & 22.83 & 24.61 & 24.78 & 24.66 & 24.46 & 26.32 & 28.01 & 27.75 & 26.57 & 26.40 \\
\hline $\begin{array}{l}\text { Average net consolidated assets } \\
\text { (billions of dollars) } \ldots \ldots \ldots\end{array}$ & 1,030 & 1,092 & 1,075 & 968 & 935 & 972 & 986 & 1,002 & 1,022 & 1,072 \\
\hline
\end{tabular}




\section{A.2.-Continued}

D. Banks ranked 101 through 1,000 by assets

\begin{tabular}{|c|c|c|c|c|c|c|c|c|c|c|}
\hline Item & 1994 & 1995 & 1996 & 1997 & 1998 & 1999 & 2000 & 2001 & 2002 & 2003 \\
\hline & \multicolumn{10}{|c|}{ Effective interest rate (percent) ${ }^{4}$} \\
\hline \multicolumn{11}{|l|}{ Rates earned } \\
\hline Interest-earning assets .. & 7.57 & 8.42 & 8.41 & 8.49 & 8.32 & 7.83 & 8.50 & 7.82 & 6.40 & 5.56 \\
\hline Taxable equivalent ... & 7.67 & 8.51 & 8.50 & 8.59 & 8.44 & 7.92 & 8.56 & 7.94 & 6.51 & 5.67 \\
\hline Loans and leases, gross ... & 8.63 & 9.43 & 9.38 & 9.48 & 9.37 & 8.74 & 9.42 & 8.76 & 7.33 & 6.56 \\
\hline Net of loss provisions & 8.28 & 8.93 & 8.76 & 8.76 & 8.76 & 8.26 & 8.75 & 7.87 & 6.57 & 6.02 \\
\hline Securities.$\ldots \ldots \ldots \ldots \ldots$ & 5.68 & 6.24 & 6.34 & 6.43 & 6.31 & 6.03 & 6.45 & 5.96 & 4.93 & 3.80 \\
\hline Taxable equivalent & 5.93 & 6.50 & 6.60 & 6.69 & 6.57 & 6.29 & 6.71 & 6.24 & 5.19 & 4.05 \\
\hline Investment account $\ldots \ldots \ldots \ldots \ldots \ldots$ & 5.68 & 6.24 & 6.34 & 6.43 & 6.30 & 6.03 & 6.45 & 5.96 & 4.93 & 3.82 \\
\hline \multicolumn{9}{|l|}{ U.S. Treasury securities and U.S. } & 4.54 & 3,42 \\
\hline Mortgage-backed securities $\ldots \ldots \ldots$ & $\begin{array}{l}\text { In.a. } \\
\text { n.a. }\end{array}$ & $\begin{array}{l}11 . \mathrm{a} . \\
\text { n.a. }\end{array}$ & $\begin{array}{l}\text { n.a. } \\
\text { n.a. }\end{array}$ & $\begin{array}{l}\text { n.a. } \\
\text { n.a. }\end{array}$ & $\begin{array}{l}\text { 11.a. } \\
\text { n.a. }\end{array}$ & $\begin{array}{l}\text { l..a. } \\
\text { n.a. }\end{array}$ & $\begin{array}{l}\text { n.a. } \\
\text { n.a. }\end{array}$ & $\begin{array}{l}5.85 \\
6.33\end{array}$ & $\begin{array}{l}4.54 \\
5.38\end{array}$ & $\begin{array}{l}3.42 \\
3.95\end{array}$ \\
\hline Other $\ldots \ldots \ldots \ldots \ldots \ldots$ & n.a. & n.a. & $\begin{array}{l}\text { II.a. } \\
\text { n.a. }\end{array}$ & $\begin{array}{l}\text { li.a. } \\
\text { n.a. }\end{array}$ & n.a. & $\begin{array}{l}\text { II.a. } \\
\text { n.a. }\end{array}$ & n.a. & 5.40 & 4.51 & 4.07 \\
\hline Trading account $\ldots \ldots \ldots \ldots \ldots \ldots \ldots \ldots$ & 5.29 & 5.55 & 5.94 & 6.37 & 6.84 & 7.33 & 9.30 & 6.60 & 3.82 & 1.67 \\
\hline Gross federal funds sold and reverse RPs & 4.05 & 5.45 & 5.29 & 5.42 & 5.31 & 4.98 & 6.15 & 3.91 & 1.73 & 1.27 \\
\hline Interest-bearing balances at depositories .. & 4.28 & 6.07 & 5.69 & 5.44 & 5.76 & 5.07 & 5.76 & 3.93 & 1.79 & 1.27 \\
\hline \multicolumn{11}{|l|}{ Rates paid } \\
\hline Interest-bearing liabilities. & 3.57 & 4.64 & 4.58 & 4.66 & 4.60 & 4.19 & 4.93 & 4.11 & 2.54 & 1.88 \\
\hline Interest-bearing deposits & 3.31 & 4.26 & 4.27 & 4.34 & 4.28 & 3.84 & 4.46 & 3.81 & 2.28 & 1.60 \\
\hline In foreign offices .... & 4.31 & 5.94 & 5.72 & 5.42 & 5.55 & 5.07 & 6.12 & 4.27 & 2.14 & 1.43 \\
\hline In domestic offices ......... & 3.28 & 4.21 & 4.23 & 4.32 & 4.25 & 3.82 & 4.43 & 3.81 & 2.28 & 1.61 \\
\hline Other checkable deposits & 1.87 & 2.02 & 1.96 & 2.16 & 2.15 & 1.99 & 2.27 & 1.81 & 1.06 & .74 \\
\hline Savings (including MMDAs) . & 2.64 & 3.24 & 3.11 & 3.08 & 2.97 & 2.65 & 3.07 & 2.22 & 1.17 & .75 \\
\hline Large time deposits 5 ........ & 4.23 & 5.62 & 5.48 & 5.56 & 5.51 & 5.17 & 6.00 & 5.27 & 3.34 & 2.57 \\
\hline Other time deposits ${ }^{5} \quad \ldots \ldots \ldots \ldots$ & 4.40 & 5.53 & 5.57 & 5.57 & 5.64 & 5.11 & 5.74 & 5.51 & 3.77 & 2.86 \\
\hline Gross federal funds purchased and RPs .. & 4.12 & 5.61 & 5.16 & 5.21 & 5.14 & 4.83 & 5.95 & 3.82 & 1.83 & 1.29 \\
\hline \multirow[t]{2}{*}{ Other interest-bearing liabilities ........... } & 4.92 & 6.28 & 5.90 & 6.09 & 6.00 & 5.36 & 6.45 & 5.41 & 4.17 & 3.59 \\
\hline & \multicolumn{10}{|c|}{ Income and expense as a percentage of average net consolidated assets } \\
\hline Gross interest income . & 6.89 & 7.68 & 7.68 & 7.75 & 7.63 & 7.19 & 7.79 & 7.16 & 5.85 & 5.07 \\
\hline Taxable equivalent & 6.98 & 7.76 & 7.75 & 7.83 & 7.71 & 7.27 & 7.86 & 7.24 & 5.93 & 5.15 \\
\hline Loans $. . . \ldots \ldots \ldots . . .$. & 5.25 & 5.98 & 5.99 & 6.00 & 5.85 & 5.47 & 5.96 & 5.59 & 4.58 & 4.07 \\
\hline 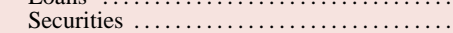 & 1.45 & 1.43 & 1.42 & 1.50 & 1.50 & 1.51 & 1.57 & 1.33 & 1.15 & .91 \\
\hline Gross federal funds sold and reverse RPs & .14 & .21 & .20 & .19 & .22 & .17 & .21 & $\begin{array}{r}1.53 \\
.16\end{array}$ & .07 & .05 \\
\hline Other $\ldots \ldots \ldots \ldots \ldots \ldots \ldots \ldots \ldots$ & .06 & .07 & .06 & .06 & .06 & .04 & .04 & .04 & .02 & .01 \\
\hline Gross interest expense & 2.65 & 3.46 & 3.40 & 3.47 & 3.44 & 3.20 & 3.79 & 3.14 & 1.92 & 1.41 \\
\hline Deposits ............ & 2.01 & 2.56 & 2.57 & 2.70 & 2.71 & 2.44 & 2.87 & 2.48 & 1.49 & 1.04 \\
\hline Gross federal funds purchased and RPs & .35 & .46 & .43 & .37 & .32 & .34 & .38 & .22 & .09 & .07 \\
\hline Other $\ldots \ldots \ldots \ldots \ldots \ldots \ldots \ldots \ldots \ldots \ldots$ & .29 & .44 & .40 & .40 & .41 & .42 & .54 & .44 & .34 & .30 \\
\hline Net interest income .... & 4.24 & 4.23 & 4.27 & 4.28 & 4.19 & 3.99 & 4.00 & 4.02 & 3.93 & 3.67 \\
\hline Taxable equivalent & 4.33 & 4.31 & 4.35 & 4.36 & 4.27 & 4.07 & 4.07 & 4.10 & 4.00 & 3.74 \\
\hline Loss provisioning 6 & .32 & .43 & .50 & .56 & .48 & .39 & .52 & .65 & .55 & .40 \\
\hline Non-interest income ......... & 1.86 & 1.84 & 1.88 & 2.08 & 2.25 & 2.31 & 2.35 & 2.37 & 2.37 & 2.31 \\
\hline Service charges on deposits & .42 & .42 & .41 & .40 & .39 & .38 & .36 & .39 & .41 & .41 \\
\hline Fiduciary activities $\ldots \ldots \ldots \ldots$. & .28 & .27 & .29 & .32 & .37 & .38 & .44 & .40 & .35 & .31 \\
\hline Trading income $\ldots \ldots \ldots \ldots$ & .02 & .03 & .02 & .01 & .02 & .02 & .01 & $*$ & $*$ & .01 \\
\hline Interest rate exposures $\ldots \ldots \ldots \ldots \ldots$ & n.a. & n.a. & .01 & .01 & .01 & .01 & .01 & -.01 & $*$ & .01 \\
\hline Foreign exchange rate exposures ...... & n.a. & n.a. & .01 & $*$ & $*$ & $*$ & $*$ & $*$ & $*$ & $*$ \\
\hline Other commodity and equity exposures & n.a. & n.a. & $*$ & $*$ & * & * & * & * & $*$ & $*$ \\
\hline Other $\ldots \ldots \ldots \ldots \ldots \ldots \ldots \ldots \ldots \ldots$ & 1.14 & 1.12 & 1.16 & 1.34 & 1.47 & 1.53 & 1.55 & 1.58 & 1.61 & 1.59 \\
\hline Non-interest expense $\ldots \ldots \ldots \ldots \ldots \ldots$ & 3.77 & 3.68 & 3.69 & 3.73 & 3.86 & 3.70 & 3.84 & 3.88 & 3.73 & 3.59 \\
\hline Salaries, wages, and employee benefits & 1.49 & 1.44 & 1.44 & 1.50 & 1.57 & 1.56 & 1.59 & 1.61 & 1.64 & 1.64 \\
\hline Occupancy $\quad \ldots \ldots \ldots \ldots \ldots \ldots \ldots$ & .46 & .45 & .45 & .46 & .47 & .47 & .47 & .46 & .45 & .43 \\
\hline 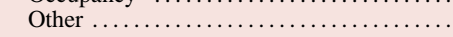 & 1.83 & 1.79 & 1.80 & 1.76 & 1.83 & 1.68 & 1.78 & 1.81 & 1.64 & 1.53 \\
\hline Net non-interest expense...$\ldots \ldots \ldots$ & 1.92 & 1.84 & 1.81 & 1.65 & 1.61 & 1.39 & 1.48 & 1.52 & 1.36 & 1.28 \\
\hline Gains on investment account securities $\ldots$ & -.05 & -.01 & .02 & .02 & .04 & -.01 & -.04 & .05 & .04 & .05 \\
\hline Income before taxes and extraordinary items & 1.96 & 1.96 & 1.98 & 2.10 & 2.14 & 2.19 & 1.96 & 1.90 & 2.06 & 2.04 \\
\hline Taxes $\ldots \ldots \ldots$ & .67 & .67 & $\begin{array}{r}.69 \\
.69\end{array}$ & .73 & .73 & .74 & .67 & .66 & .67 & .66 \\
\hline Extraordinary items, net of income taxes & $*$ & $*$ & $*$ & $*$ & .06 & .01 & $*$ & .01 & $*$ & .03 \\
\hline Net income $\ldots \ldots \ldots \ldots$. & 1.29 & 1.28 & 1.29 & 1.37 & 1.46 & 1.46 & 1.29 & 1.25 & 1.38 & 1.40 \\
\hline Cash dividends declared & .81 & .87 & 1.04 & 1.09 & 1.01 & 1.06 & .92 & 1.33 & 1.19 & 1.64 \\
\hline Retained income ....... & .48 & .41 & .25 & .28 & .45 & .40 & .37 & -.08 & .19 & -.24 \\
\hline Mемо: Return on equity . & 15.42 & 14.82 & 14.45 & 14.90 & 15.49 & 16.11 & 14.22 & 12.95 & 13.74 & 13.62 \\
\hline
\end{tabular}

* In absolute value, less than 0.005 percent.

n.a. Not available. MMDA Money market deposit account. RP Repurchase agreement. CD Certificate of deposit.

1. Includes allocated transfer risk reserves.

2. As in the Call Report, equity securities were combined with "other debt securities" before 1989.

3. Before 1994, the netted value of revaluation gains and losses appeared in "trading account securities"

if it was a gain and in "other non-interest-bearing liabilities" if it was a loss.

4. When possible, based on the average of quarterly balance sheet data reported on schedule RC-K of the quarterly Call Reports.

5. Before 1997, large time open accounts included in other time deposits.

6. Includes provisions for allocated transfer risk 
A.2. Portfolio composition, interest rates, and income and expense, all U.S. banks, 1994-2003 E. Banks not ranked among the 1,000 largest by assets

\begin{tabular}{|c|c|c|c|c|c|c|c|c|c|c|}
\hline Item & 1994 & 1995 & 1996 & 1997 & 1998 & 1999 & 2000 & 2001 & 2002 & 2003 \\
\hline & \multicolumn{10}{|c|}{ Balance sheet items as a percentage of average net consolidated assets } \\
\hline Interest-earning assets . & 92.48 & 92.48 & 92.45 & 92.44 & 92.64 & 92.55 & 92.52 & 92.25 & 92.22 & 92.13 \\
\hline Loans and leases, net $\ldots \ldots \ldots$ & 54.64 & 56.61 & 57.38 & 58.75 & 59.11 & 59.75 & 62.31 & 62.67 & 62.72 & 62.33 \\
\hline Commercial and industrial & 9.31 & 9.65 & 9.98 & 10.16 & 10.33 & 10.64 & 11.09 & 11.10 & 10.71 & 10.43 \\
\hline U.S. addressees ......... & 9.27 & 9.59 & 9.90 & 10.08 & 10.25 & 10.55 & 11.02 & 11.02 & 10.65 & 10.37 \\
\hline Foreign addressees $\ldots . .$. & .05 & .06 & .07 & .08 & .08 & .08 & .07 & .08 & .06 & .05 \\
\hline Consumer $\ldots \ldots \ldots \ldots$ & 9.38 & 9.54 & 9.42 & 8.98 & 8.46 & 8.15 & 7.97 & 7.42 & 6.76 & 6.16 \\
\hline Credit card .......... & .96 & 1.01 & 1.04 & .85 & .70 & .68 & .58 & .57 & .49 & .51 \\
\hline Installment and other & 8.41 & 8.53 & 8.38 & 8.14 & 7.76 & 7.47 & 7.39 & 6.85 & 6.28 & 5.64 \\
\hline Real estate ........... & 32.18 & 33.55 & 34.10 & 35.55 & 36.04 & 36.84 & 39.30 & 40.31 & 41.52 & 42.31 \\
\hline In domestic offices & 32.18 & 33.54 & 34.10 & 35.54 & 36.04 & 36.84 & 39.29 & 40.30 & 41.52 & 42.31 \\
\hline Construction and land development & 2.14 & 2.38 & 2.61 & 2.82 & 3.02 & 3.28 & 3.70 & 4.23 & 4.51 & 4.99 \\
\hline Farmland $\ldots \ldots \ldots \ldots \ldots \ldots \ldots \ldots$ & 2.34 & 2.48 & 2.55 & 2.69 & 2.83 & 2.95 & 3.06 & 3.04 & 3.08 & 3.12 \\
\hline One- to four-family residential ... & 16.94 & 17.45 & 17.48 & 18.16 & 18.04 & 17.66 & 18.43 & 18.25 & 17.91 & 17.10 \\
\hline Home equity $\ldots \ldots \ldots \ldots \ldots$ & 1.21 & 1.20 & 1.20 & 1.24 & 1.21 & 1.17 & 1.28 & 1.37 & 1.62 & 1.80 \\
\hline Other ......... & 15.73 & 16.25 & 16.28 & 16.92 & 16.84 & 16.49 & 17.15 & 16.87 & 16.29 & 15.30 \\
\hline Multifamily residential & .93 & .95 & .92 & .95 & .93 & .98 & 1.04 & 1.06 & 1.16 & 1.28 \\
\hline Nonfarm nonresidential & 9.83 & 10.28 & 10.54 & 10.92 & 11.21 & 11.97 & 13.06 & 13.72 & 14.86 & 15.82 \\
\hline In foreign offices $\ldots \ldots \ldots \ldots \ldots \ldots$ & * & $*$ & * & * & $*$ & $*$ & $*$ & $*$ & $*$ & * \\
\hline \\
\hline $\begin{array}{c}\text { of other banks } \ldots \ldots \ldots \ldots \ldots \ldots \ldots \ldots \\
\text { Foreign governments }\end{array}$ & .17 & .19 & .21 & .20 & .14 & .14 & .12 & .12 & .10 & .09 \\
\hline Foreign governments ... & .01 & * & $*$ & * & $*$ & .01 & .01 & * & * & * \\
\hline Agricultural production & 3.89 & 3.95 & 3.92 & 4.05 & 4.28 & 4.06 & 3.85 & 3.76 & 3.64 & 3.39 \\
\hline 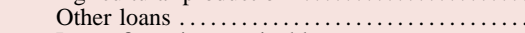 & .77 & .72 & .69 & .67 & .67 & .67 & .69 & .67 & .65 & .66 \\
\hline Lease-financing receivables & .20 & .22 & .23 & .25 & .24 & .26 & .27 & .27 & .31 & .26 \\
\hline LEsS: Unearned income on loans & -.31 & -.30 & -.27 & -.24 & -.20 & -.15 & -.11 & -.09 & -.07 & -.06 \\
\hline LEss: Loss reserves ${ }^{1} \ldots \ldots \ldots \ldots$ & -.95 & -.93 & -.90 & -.87 & -.86 & -.87 & $\begin{array}{l}-.11 \\
-.88\end{array}$ & -.88 & -.01 & -.92 \\
\hline Securities .............. & 32.90 & 30.51 & 29.53 & 28.25 & 26.70 & 26.92 & 25.40 & 22.81 & 23.34 & 23.46 \\
\hline Investment account & 32.86 & 30.48 & 29.50 & 28.21 & 26.66 & 26.88 & 25.38 & 22.80 & 23.33 & 23.42 \\
\hline Debt $\ldots \ldots \ldots$ & 32.43 & 30.03 & 29.01 & 27.69 & 26.12 & 26.35 & 24.82 & 22.49 & 23.06 & 23.11 \\
\hline U.S. Treasury $\ldots \ldots \ldots \ldots$ & 10.75 & 9.19 & 7.85 & 6.70 & 5.05 & 3.34 & 2.12 & 1.33 & 1.04 & .90 \\
\hline \multicolumn{11}{|l|}{ U.S. government agency and } \\
\hline corporation obligations $\ldots \ldots \ldots$ & 15.25 & 15.13 & 15.67 & 15.58 & 15.43 & 16.89 & 16.95 & 15.27 & 16.07 & 16.22 \\
\hline Government-backed mortgage pools & 4.73 & 4.19 & 4.21 & 4.01 & 3.90 & 3.95 & 3.47 & 3.78 & 4.54 & 4.84 \\
\hline Collateralized mortgage obligations & 3.05 & 2.76 & 2.46 & 2.19 & 2.02 & 2.00 & 1.70 & 1.94 & 2.30 & 2.20 \\
\hline Other $\ldots \ldots \ldots \ldots \ldots \ldots \ldots \ldots$ & 7.47 & 8.19 & 9.00 & 9.38 & 9.51 & 10.94 & 11.78 & 9.56 & 9.23 & 9.18 \\
\hline State and local government ....... & 5.00 & 4.70 & 4.62 & 4.60 & 4.80 & 4.96 & 4.64 & 4.51 & 4.56 & 4.73 \\
\hline Private mortgage-backed securities .. & .26 & .20 & .18 & .19 & .16 & .26 & .23 & .27 & .26 & .21 \\
\hline Other $\ldots \ldots \ldots \ldots \ldots \ldots \ldots \ldots \ldots$ & .96 & .82 & .68 & 61 & .68 & .89 & .88 & 1.11 & 1.12 & 1.05 \\
\hline Equity $^{2} \ldots \ldots$ & .43 & .45 & .49 & .52 & .54 & .53 & .56 & .30 & .27 & .31 \\
\hline Trading account & .04 & .03 & .03 & .03 & .04 & .03 & .02 & .01 & .01 & .03 \\
\hline Gross federal funds sold and reverse RPs & 3.42 & 3.91 & 4.04 & 3.95 & 5.13 & 4.17 & 3.22 & 5.00 & 4.26 & 4.27 \\
\hline Interest-bearing balances at depositories .. & 1.52 & 1.45 & 1.51 & 1.49 & 1.72 & 1.71 & 1.59 & 1.77 & 1.89 & 2.08 \\
\hline Non-interest-earning assets ................. & 7.52 & 7.52 & 7.55 & 7.56 & 7.36 & 7.45 & 7.48 & 7.75 & 7.78 & 7.87 \\
\hline Revaluation gains held in trading accounts ${ }^{3}$ & $*$ & $*$ & $*$ & $*$ & $*$ & * & $*$ & $*$ & $*$ & $*$ \\
\hline 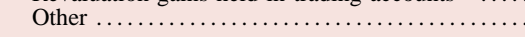 & 7.52 & 7.52 & 7.55 & 7.56 & 7.36 & 7.45 & 7.48 & 7.75 & 7.78 & 7.87 \\
\hline Liabilities ................ & 90.43 & 90.04 & 89.81 & 89.63 & 89.54 & 89.75 & 89.89 & 89.60 & 89.73 & 89.58 \\
\hline Interest-bearing liabilities & 76.18 & 75.74 & 75.58 & 75.47 & 75.35 & 75.90 & 76.05 & 76.00 & 76.01 & 75.47 \\
\hline Deposits $\ldots \ldots \ldots \ldots \ldots \ldots \ldots$ & 73.14 & 72.70 & 72.47 & 72.05 & 71.77 & 71.41 & 70.54 & 70.94 & 70.50 & 69.82 \\
\hline In foreign offices .. & .09 & .11 & .10 & .09 & .07 & .07 & .05 & .06 & .06 & .05 \\
\hline In domestic offices $\ldots \ldots \ldots$ & 73.05 & 72.59 & 72.37 & 71.96 & 71.70 & 71.34 & 70.48 & 70.88 & 70.45 & 69.77 \\
\hline Other checkable deposits ... & 13.31 & 12.37 & 11.75 & 11.39 & 11.18 & 11.07 & 10.57 & 10.19 & 10.42 & 10.60 \\
\hline Savings (including MMDAs) & 23.23 & 20.41 & 19.58 & 18.98 & 19.01 & 19.69 & 19.03 & 19.14 & 20.99 & 22.00 \\
\hline Small-denomination time deposits .. & 28.83 & 30.92 & 31.28 & 31.09 & 30.42 & 29.07 & 28.42 & 28.08 & 25.91 & 24.20 \\
\hline Large-denomination time deposits & 7.67 & 8.89 & 9.76 & 10.50 & 11.10 & 11.50 & 12.47 & 13.48 & 13.13 & 12.97 \\
\hline Gross federal funds purchased and RPs ... & 1.89 & 1.78 & 1.71 & 1.67 & 1.49 & 1.79 & 2.06 & 1.55 & 1.51 & 1.52 \\
\hline 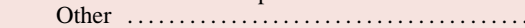 & 1.16 & 1.25 & 1.41 & 1.74 & 2.09 & 2.70 & 3.45 & 3.51 & 4.00 & 4.13 \\
\hline Non-interest-bearing liabilities $\ldots \ldots \ldots \ldots \ldots$ & 14.25 & 14.30 & 14.23 & 14.16 & 14.19 & 13.86 & 13.84 & 13.59 & 13.71 & 14.11 \\
\hline Demand deposits in domestic offices ............. & 13.34 & 13.23 & 13.12 & 13.09 & 13.08 & 12.80 & 12.64 & 12.16 & 12.24 & 12.57 \\
\hline Revaluation losses held in trading accounts ${ }^{3}$ & $*$ & $*$ & $*$ & $*$ & $*$ & * & $*$ & $*$ & $*$ & $*$ \\
\hline 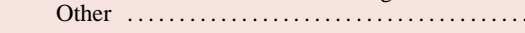 & .90 & 1.07 & 1.10 & 1.06 & 1.10 & 1.06 & 1.20 & 1.43 & 1.47 & 1.53 \\
\hline Capital account & 9.57 & 9.96 & 10.19 & 10.37 & 10.46 & 10.25 & 10.11 & 10.40 & 10.27 & 10.42 \\
\hline Мемо & & & & & & & & & & \\
\hline Commercial real estate loans & 13.02 & 13.72 & 14.18 & 14.80 & 15.26 & 16.33 & 17.92 & 19.15 & 20.68 & 22.23 \\
\hline Other real estate owned .......... & .35 & .25 & .20 & .16 & .13 & .11 & .11 & .12 & .14 & .15 \\
\hline Managed liabilities ................ & 10.83 & 12.05 & 12.99 & 14.02 & 14.76 & 16.08 & 18.08 & 18.66 & 18.79 & 18.78 \\
\hline $\begin{array}{l}\text { Average net consolidated assets } \\
\text { (billions of dollars) } \ldots \ldots \ldots\end{array}$ & 679 & 666 & 661 & 647 & 644 & 651 & 655 & 674 & 704 & 742 \\
\hline
\end{tabular}




\section{A.2.-Continued}

E. Banks not ranked among the 1,000 largest by assets

\begin{tabular}{|c|c|c|c|c|c|c|c|c|c|c|}
\hline Item & 1994 & 1995 & 1996 & 1997 & 1998 & 1999 & 2000 & 2001 & 2002 & 2003 \\
\hline & & & & Eff & ive inter & rate $(\mathrm{pe}$ & $n t)^{4}$ & & & \\
\hline \multicolumn{11}{|l|}{ Rates earned } \\
\hline Interest-earning assets . & 7.58 & 8.38 & 8.36 & 8.49 & 8.33 & 8.05 & 8.46 & 7.91 & 6.80 & 5.92 \\
\hline Taxable equivalent .. & 7.72 & 8.53 & 8.50 & 8.63 & 8.48 & 8.18 & 8.56 & 8.05 & 6.93 & 6.06 \\
\hline Loans and leases, gross ... & 9.01 & 9.80 & 9.75 & 9.80 & 9.69 & 9.28 & 9.51 & 9.03 & 7.87 & 7.10 \\
\hline Net of loss provisions & 8.81 & 9.54 & 9.47 & 9.49 & 9.34 & 8.89 & 9.14 & 8.59 & 7.42 & 6.75 \\
\hline Securities $\ldots \ldots \ldots \ldots \ldots \ldots$ & 5.61 & 6.10 & 6.14 & 6.26 & 6.04 & 5.88 & 6.15 & 5.86 & 5.02 & 3.86 \\
\hline Taxable equivalent & 5.99 & 6.49 & 6.52 & 6.65 & 6.46 & 6.29 & 6.54 & 6.28 & 5.43 & 4.26 \\
\hline Investment account $\ldots \ldots \ldots \ldots \ldots \ldots$ & 5.61 & 6.10 & 6.14 & 6.26 & 6.04 & 5.89 & 6.15 & 5.86 & 5.02 & 3.87 \\
\hline \multicolumn{10}{|l|}{ U.S. Treasury securities and U.S. } & 374 \\
\hline Mortgage-backed securities $\ldots \ldots \ldots$ & $\begin{array}{l}\text { Il.a. } \\
\text { n.a. }\end{array}$ & $\begin{array}{l}\text { ll.a. } \\
\text { n.a. }\end{array}$ & $\begin{array}{l}\text { n.a. } \\
\text { n.a. }\end{array}$ & $\begin{array}{l}\text { n.a. } \\
\text { n.a. }\end{array}$ & $\begin{array}{l}\text { II.a. } \\
\text { n.a. }\end{array}$ & $\begin{array}{l}\text { li.d. } \\
\text { n.a. }\end{array}$ & $\begin{array}{l}\text { n.a. } \\
\text { n.a. }\end{array}$ & $\begin{array}{l}5.97 \\
6.20\end{array}$ & $\begin{array}{l}4.80 \\
5.47\end{array}$ & $\begin{array}{l}3.74 \\
3.58\end{array}$ \\
\hline Other $\ldots \ldots \ldots \ldots \ldots \ldots \ldots \ldots \ldots$ & n.a. & n.a. & $\begin{array}{l}\text { II.a. } \\
\text { n.a. }\end{array}$ & n.a. & n.a. & n.a. & n.a. & 5.29 & 4.87 & 4.43 \\
\hline Trading account $\ldots \ldots \ldots \ldots \ldots \ldots \ldots \ldots$ & 6.03 & 6.12 & 6.47 & 6.33 & 5.26 & 3.60 & 4.01 & 6.43 & 4.80 & .66 \\
\hline Gross federal funds sold and reverse RPs & 4.09 & 5.95 & 5.34 & 5.51 & 5.35 & 4.96 & 6.25 & 3.83 & 1.63 & 1.08 \\
\hline Interest-bearing balances at depositories..... & 4.64 & 5.88 & 5.63 & 5.62 & 5.67 & 5.69 & 6.38 & 4.56 & 2.68 & 1.96 \\
\hline \multicolumn{11}{|l|}{ Rates paid } \\
\hline Interest-bearing liabilities. & 3.49 & 4.46 & 4.49 & 4.60 & 4.60 & 4.28 & 4.80 & 4.40 & 2.92 & 2.13 \\
\hline Interest-bearing deposits & 3.44 & 4.39 & 4.44 & 4.53 & 4.53 & 4.22 & 4.67 & 4.32 & 2.78 & 2.02 \\
\hline In foreign offices .... & 3.92 & 5.73 & 5.34 & 4.77 & 5.08 & 4.34 & 5.13 & 4.04 & 1.67 & .85 \\
\hline In domestic offices ......... & 3.44 & 4.39 & 4.44 & 4.53 & 4.53 & 4.22 & 4.67 & 4.32 & 2.79 & 2.02 \\
\hline Other checkable deposits & 2.30 & 2.50 & 2.41 & 2.46 & 2.45 & 2.28 & 2.47 & 1.97 & 1.16 & .78 \\
\hline Savings (including MMDAs). & 2.83 & 3.32 & 3.26 & 3.36 & 3.39 & 3.21 & 3.56 & 2.81 & 1.72 & 1.13 \\
\hline Large time deposits 5 ....... & 4.12 & 5.55 & 5.48 & 5.53 & 5.53 & 5.22 & 5.89 & 5.53 & 3.61 & 2.78 \\
\hline Other time deposits ${ }^{5} \quad \ldots \ldots \ldots \ldots \ldots$ & 4.28 & 5.51 & 5.61 & 5.66 & 5.63 & 5.25 & 5.70 & 5.60 & 3.88 & 2.96 \\
\hline Gross federal funds purchased and RPs ...... & 4.11 & 5.60 & 5.12 & 5.23 & 4.99 & 4.73 & 5.69 & 3.92 & 1.84 & 1.31 \\
\hline \multirow[t]{2}{*}{ Other interest-bearing liabilities $\ldots \ldots \ldots \ldots \ldots$} & 5.02 & 6.45 & 5.77 & 6.31 & 6.45 & 5.63 & 6.22 & 5.74 & 5.31 & 4.06 \\
\hline & \multicolumn{10}{|c|}{ Income and expense as a percentage of average net consolidated assets } \\
\hline Gross interest income . & 7.02 & 7.78 & 7.77 & 7.90 & 7.75 & 7.48 & 7.83 & 7.35 & 6.33 & 5.48 \\
\hline Taxable equivalent & 7.16 & 7.91 & 7.89 & 8.02 & 7.87 & 7.60 & 7.95 & 7.45 & 6.43 & 5.58 \\
\hline Loans $\ldots . . \ldots \ldots \ldots$ & 4.99 & 5.63 & 5.68 & 5.86 & 5.80 & 5.62 & 5.99 & 5.75 & 5.03 & 4.49 \\
\hline Securities $\ldots \ldots \ldots \ldots \ldots \ldots \ldots \ldots \ldots \ldots$ & 1.84 & 1.86 & 1.80 & 1.76 & 1.59 & 1.58 & 1.57 & 1.32 & 1.16 & .89 \\
\hline Gross federal funds sold and reverse RPs & .15 & .25 & .24 & .24 & .29 & .22 & .21 & .20 & .07 & .05 \\
\hline 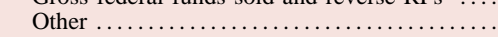 & .04 & .04 & .04 & .04 & .06 & .06 & .05 & .05 & .03 & .03 \\
\hline Gross interest expense & 2.65 & 3.37 & 3.39 & 3.48 & 3.46 & 3.26 & 3.64 & 3.34 & 2.23 & 1.60 \\
\hline Deposits ............ & 2.52 & 3.19 & 3.22 & 3.28 & 3.25 & 3.03 & 3.30 & 3.08 & 1.98 & 1.41 \\
\hline Gross federal funds purchased and RPs & .07 & .10 & .08 & .08 & .07 & .08 & .12 & .06 & .03 & .02 \\
\hline Other $\ldots \ldots \ldots \ldots \ldots \ldots \ldots \ldots \ldots \ldots$ & .06 & .08 & .08 & .11 & .13 & .15 & .21 & .20 & .21 & .17 \\
\hline Net interest income .... & 4.36 & 4.41 & 4.38 & 4.42 & 4.28 & 4.22 & 4.20 & 4.01 & 4.10 & 3.88 \\
\hline Taxable equivalent & 4.50 & 4.54 & 4.50 & 4.54 & 4.41 & 4.35 & 4.31 & 4.12 & 4.21 & 3.98 \\
\hline Loss provisioning 6 & .19 & .24 & .25 & .27 & .29 & .31 & .31 & .36 & .35 & .29 \\
\hline Non-interest income....... & 1.30 & 1.38 & 1.42 & 1.42 & 1.52 & 1.44 & 1.32 & 1.31 & 1.39 & 1.46 \\
\hline Service charges on deposits & .44 & .44 & .44 & .44 & .42 & .42 & .43 & .44 & .45 & .43 \\
\hline Fiduciary activities..$\ldots \ldots \ldots$ & .17 & .22 & .19 & .20 & .23 & .26 & .21 & .25 & .27 & .28 \\
\hline Trading income........ & $*$ & .01 & $*$ & $*$ & $*$ & $*$ & .01 & $*$ & $*$ & $*^{20}$ \\
\hline Interest rate exposures $\ldots \ldots \ldots \ldots \ldots$ & n.a. & n.a. & $*$ & * & $*$ & $*$ & $*$ & $*$ & $*$ & $*$ \\
\hline Foreign exchange rate exposures ...... & n.a. & n.a. & $*$ & $*$ & $*$ & $*$ & $*$ & * & $*$ & $*$ \\
\hline Other commodity and equity exposures & n.a. & n.a. & $*$ & $*$ & $*$ & $*$ & $*$ & * & $*$ & $*$ \\
\hline Other $\ldots \ldots \ldots \ldots \ldots \ldots \ldots \ldots \ldots \ldots$ & .69 & .71 & .79 & .77 & .86 & .75 & .67 & .62 & .67 & .75 \\
\hline Non-interest expense $\ldots \ldots \ldots \ldots \ldots \ldots$ & 3.79 & 3.80 & 3.70 & 3.69 & 3.74 & 3.73 & 3.58 & 3.55 & 3.57 & 3.55 \\
\hline Salaries, wages, and employee benefits & 1.75 & 1.79 & 1.77 & 1.80 & 1.82 & 1.82 & 1.78 & 1.79 & 1.82 & 1.82 \\
\hline Occupancy $\ldots \ldots \ldots \ldots \ldots \ldots \ldots \ldots$ & .49 & .50 & .49 & .49 & .49 & .49 & .47 & .47 & .46 & .45 \\
\hline 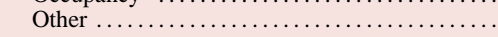 & 1.55 & 1.51 & 1.44 & 1.40 & 1.43 & 1.42 & 1.32 & 1.29 & 1.28 & 1.28 \\
\hline Net non-interest expense $\ldots \ldots \ldots \ldots \ldots$. & 2.48 & 2.42 & 2.28 & 2.28 & 2.23 & 2.29 & 2.26 & 2.24 & 2.18 & 2.09 \\
\hline Gains on investment account securities & -.03 & $*$ & .01 & .01 & .02 & $*$ & -.01 & .04 & .05 & .04 \\
\hline Income before taxes and extraordinary items .... & 1.66 & 1.75 & 1.85 & 1.89 & 1.79 & 1.62 & 1.61 & 1.45 & 1.60 & 1.53 \\
\hline Taxes $\ldots \ldots \ldots \ldots \ldots \ldots$ & .51 & .55 & .59 & .59 & .53 & .46 & .45 & .39 & .41 & .38 \\
\hline Extraordinary items, net of income taxes $\ldots . .$. & * & $*$ & $*$ & $*$ & $*$ & $*$ & $*$ & $*$ & -.01 & $*$ \\
\hline Net income $\ldots \ldots \ldots \ldots$. & 1.15 & 1.20 & 1.26 & 1.30 & 1.26 & 1.15 & 1.17 & 1.06 & 1.18 & 1.14 \\
\hline Cash dividends declared & .57 & .62 & .64 & .74 & .82 & .68 & .79 & .64 & .68 & .67 \\
\hline Retained income ....... & .58 & .58 & .62 & .56 & .44 & .48 & .38 & .42 & .50 & .47 \\
\hline Мемо: Return on equity . & 12.03 & 12.05 & 12.37 & 12.53 & 12.02 & 11.25 & 11.53 & 10.17 & 11.47 & 10.98 \\
\hline
\end{tabular}

* In absolute value, less than 0.005 percent.

n.a. Not available. MMDA Money market deposit account. RP Repurchase agreement. CD Certificate of deposit.

1. Includes allocated transfer risk reserves.

2. As in the Call Report, equity securities were combined with "other debt securities" before 1989.

3. Before 1994, the netted value of revaluation gains and losses appeared in "trading account securities"

if it was a gain and in "other non-interest-bearing liabilities" if it was a loss.

4. When possible, based on the average of quarterly balance sheet data reported on schedule RC-K of the quarterly Call Reports.

5. Before 1997, large time open accounts included in other time deposits.

6. Includes provisions for allocated transfer risk 